\title{
ANÁLISE HISTOLÓGICA E RADIOGRÁFICA DO POTENCIAL OSTEOPROMOTOR DA MEMBRANA DE CORTICAL ÓSSEA BOVINA NO REPARO DE DEFEITO ÓSSEO DE TAMANHO CRÍTICO NA CALVÁRIA DE
}

COBAIA. (CAVIA PORCELLUS).

Marcio Luiz Lima Taga

Dissertação apresentada à Faculdade de Odontologia de Bauru da Universidade de São Paulo, como parte dos requisitos para obtenção do Título de Mestre em Odontologia, área de Periodontia.

(Edição Revisada) 


\section{ANÁLISE HISTOLÓGICA E RADIOGRÁFICA DO POTENCIAL OSTEOPROMOTOR DA MEMBRANA DE \\ CORTICAL ÓSSEA BOVINA NO REPARO DE DEFEITO ÓSSEO DE TAMANHO CRÍTICO NA \\ CALVÁRIA DE COBAIA. (CAVIA PORCELLUS).}

\section{Marcio Luiz Lima Taga}

Dissertação apresentada à Faculdade de Odontologia de Bauru da Universidade de São Paulo, como parte dos requisitos para obtenção do Título de Mestre em Odontologia, área de Periodontia.

Orientador: Prof. Dr. José Mauro Granjeiro

(Edição Revisada) 


\section{Taga, Marcio Luiz Lima}

T126a Análise histológica e radiográfica do potencial osteopromotor da membrana de cortical óssea bovina no reparo de defeito ósseo de tamanho crítico na calvária de cobaia. (Cavia porcellus)./ Marcio Luiz Lima Taga.-- Bauru, 2005.

xxii 148 p.: il. ; 30 cm.

Dissertação (Mestrado) -- Faculdade de Odontologia de Bauru. Universidade de São Paulo.

Orientador: Prof. Dr. José Mauro Granjeiro

Autorizo, exclusivamente para fins acadêmicos e científicos, a reprodução total ou parcial desta dissertação, por processos fotocopiadores e outros meios eletrônicos.

Assinatura:

Data:

Comissão de Ética no Ensino e m Pesquisa em Animais da FOB/USP: Comissão constituída em fevereiro/2003. (pesquisa iniciada em 2001)

$N^{\circ}$ do Protocolo: -0-0-0-0-

Data: -0-0-0-0- 
1973

Filiação

1996-1999

2002-

2001-2004
Nascimento - Bauru - São Paulo

Eulázio Mikio Taga e

Maria Silvia de Lima Taga

Graduação - Curso de Odontologia na Faculdade de Odontologia de Bauru da Universidade de São Paulo.

Professor Assistente do "Curso de Implantodontia" realizado na Clinica Via Oral.

Curso de Pós-Graduação em Periodontia, em nível de Mestrado, na Faculdade de Odontologia de Bauru, USP. 


\section{DEDICATÓRIA}

Aos meus pais Eulázio e Maria Silvia que com todo esforço fizeram de mim um homem íntegro e com personalidade para que eu pudesse realizar meus objetivos de vida.

Dedico esta Dissertação à J osilene (Ninha) a qual sempre esteve ao meu lado, nos bons e complicados momentos do meu percurso, me amparando, me amando e chamando a atenção quando necessária, sendo uma MULHER de verdade e principalmente minha AMIGA a qual posso dizer e sentir: EU TE AMO. Espero passar ainda muito tempo ao seu lado, construindo uma vida nova, completa de alegria e amor.

Ao meu único e verdadeiro irmão, Marcel, que mudou radicalmente sua escolha profissional e com muito caráter e personalidade, enfrentamos as dificuldades e realizamos o que verdadeiro nos contenta.

Por final, à Faculdade de Odontologia de Bauru, onde praticamente convivi a maioria dos anos de minha vida, transformando-se na minha segunda casa. 


\section{AGRADECIMENTOS}

A DEUS, JESUS CRISTO e a AVE MARIA, que me abençoaram me dando simplesmente a minha vida e traçando meu caminho de vida. 
Agradeço às entidades CNPq Proc. $n^{\circ} 350553 / 1993-9$ eà FAPESP Proc. $n^{\circ}$ 2002/ 10831-2 pelo apoio financeiro.

À Indústria Baumer pela doação das membranas.

Ao meu orientador, Prof. Dr. José Mauro Granjeiro pelos incentivos e ensinamentos tanto nos aspectos de vida como profissional, sempre levantando meu ego. Considero-o como um irmão.

Prof. Dr. Rumio Taga pela oportunidade de trabalho e confiança depositada em mim. Trabalhou como um mentor científico, sempre instigando esse lado na minha pessoa. Além disso soube separar o profissional do familiar, colaborando com meu crescimento científico e profissional.

O meu sincero agradecimento! 
A Carla Damante, parceiros de clínica, pela compreensão das dificuldades particulares que eu enfrentava, sempre estando ao meu lado, me incentivando, me entendendo.

Aos colegas de pós-graduação, Caio, Dioracy, Milena, Estéfano, Mariana, Eric pela transmissão de ensinamentos e convívio.

Aos Professores da Disciplina de Periodontia, Prof. Dr. Euloir Passanezi, Prof. Dr. Deoclécio Nahás (In memorian), Prof. Dr. Sebastião Luiz de Aguiar Greghi, Prof ${ }^{-a}{ }^{-a}{ }^{-}$Adriana Passanezi pela atenção que me dispensaram e pelos brilhantes ensinamentos que me transmitiram desde a minha formação como Cirurgião-Dentista. Aos funcionários, Ivânia, Marcão, D. Neusa, Edilaine.

À Disciplina de Histologia onde convivi a maioria do meu tempo de Mestrado, aos Profs. Drs. Gerson, Dagoberto e Stipp, aos funcionários Daniela, "Tera" e Divina. Pelos momentos agradáveis que passei nesta disciplina.

Aos funcionários da Disciplina de Bioquímica, Telma, Ovídio, Vera e Gilmar pelos esforços e colaboração na minha Dissertação.

Ao departamento de Pós - Graduação, Biblioteca.

Aos funcionários do Biotério pela colaboração ao meu trabalho de Mestrado.

Tenho que agradecer em especial às cobaias empregadas na realização desta Dissertação, sem elas não poderíamos obter ênfase no projeto de trabalho. 
Meus Agradecimentos especiais vão para a Tânia que sempre esteve disposta e colaborou com novos trabalhos, principalmente na Dissertação, não medindo esforços na obtenção de uma Dissertação de qualidade, e pelos ensinamentos e experiências a qual me transmitiu. Uma amiga nos melhores e complicados momentos. Atuou como uma mentora científica para a minha pessoa.

Ao Daniel (Manaus) atuou como um irmão, professor, me dando oportunidades de crescer, passando-me ensinamentos e mostrando um caminho a seguir, colaborou em muito no meu crescimento profissional e intelectual. Sempre de portas abertas, dando oportunidades aos que estão no início. Consegue promover o trabalho em equipe, algo indispensável nos momentos de hoje.

Daniel tem o dom de PROFESSOR e de um SER ÍNTEGRO, um simples aspecto que vejo que o torna um PROFISSIONAL e PROFESSOR indispensável às melhores Faculdades de Odontologia do Brasil. 


\section{Sumário}

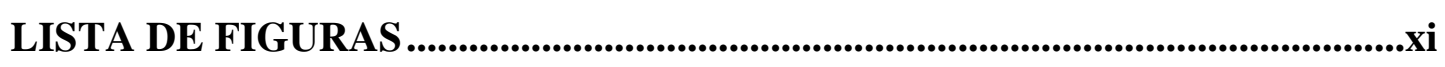

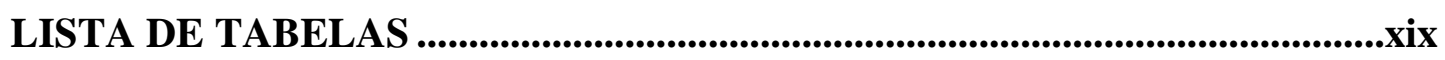

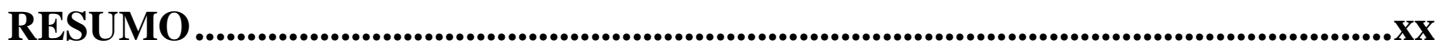

1. INTRODUÇÃ

2. REVISÃO DE LITERATURA ..................................................................9

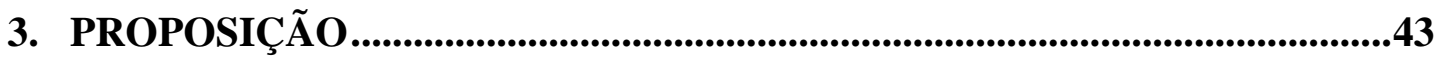

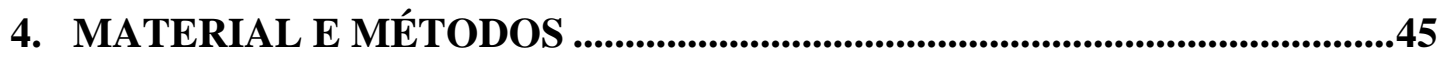

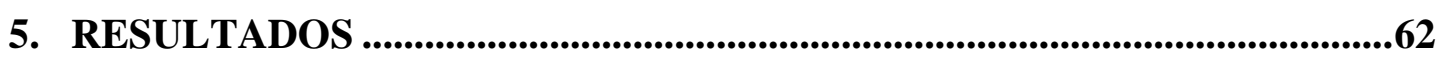

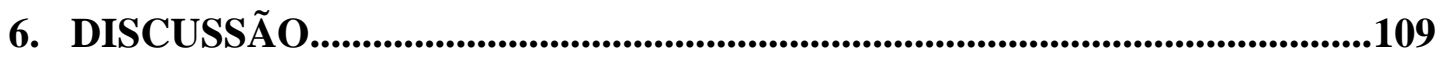

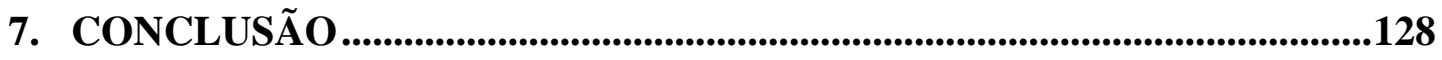

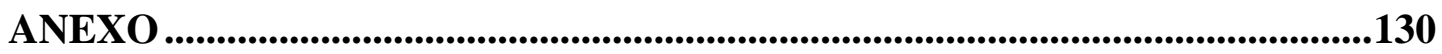

REFERÊNCIAS BIBLIOGRÁFICAS.........................................................132

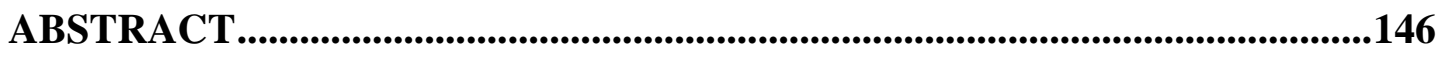




\section{LISTA DE FIGURAS}

Figura 1: Embalagem e membrana Gen-Derm

Figura 2: Esquema do procedimento para confecção do defeito ósseo na calota craniana de cobaia....

Figura 3 a-f: Procedimentos cirúrgicos: a) instrumentais utilizados; b) isolamento da área cirúrgica e assepsia da região onde foi realizada a tricotomia; c) incisão realizada em meia-lua na região fronto-parietal; d) levantamento do retalho + periósteo com exposição da superfície do crânio; e) defeito delimitado e realizado com a trefina; f) retirada do bloco ósseo de dentro do defeito através de um descolador Molt com a exposição da dura-máter

Figura 3 g-m: Procedimentos cirúrgicos: g); comparação do tamanho das membranas recortadas e da trefina utilizada; h) colocação da membrana sobre a dura--máter e abaixo da cortical interna; i) membrana + coágulo; j) colocação do suporte de osso alógeno desmineralizado e desproteinizado de 3x3mm sobre a primeira membrana; l) implantação da segunda membrana sobre a cortical externa e o suporte; m) sutura do retalho 52

Figura 4 a:Tela principal do Programa KS300 Carl Zeiss apresentando a programação “macro" devidamente montada da área do defeito .57

Figura 4. b,c: b) Programação "macro cobaia” no KS300 Carl Zeiss no modo interativo para o isolamento da área radiolúcida. c) animal do período de 6 meses. .58

Figura 4 d,e: d) Programação “macro cobaia” no KS300 Carl Zeiss durante a aplicação da máscara para isolamento da área a ser quantificada. e) animal do período de 6 meses 59 
Figura 4.f,g: f) Determinação da área radiolúcida em pixels ${ }^{2}$ na Programação “macro cobaia” no KS300 Carl Zeiss. g) animal do período de 6 meses

Figura 5: Microscopia eletrônica de varredura - detalhes dos poros da membrana de cortical óssea bovina liofilizada.

Figura 6. Imagens radiográficas dos crânios dos animais no período de 0 hora póscirúrgico (imediatamente após a cirurgia)

Figura 7. Imagens radiográficas da calvária dos animais do período de 1 mês: grupo controle (a-e) e grupo experimental (f-j)

Figura 8. Imagens radiográficas da calvária dos animais do período de 3 meses: grupo controle (a-e) e grupo experimental (f-j

Figura 9. Imagens radiográficas da calvária dos animais do período de 6 meses: grupo controle (a-e) e grupo experimental (f-j).

Figura 10. Imagens radiográficas da calvária dos animais do período de 9 meses: grupo controle (a-e) e grupo experimental (f-j). .66

Figura 11. Perfis médios com intervalo de confiança de 95\% das médias.... 69

Figura 12. Gráfico mostrando as curvas estimadas e dados - Arluc versus tempo...71

Figura 13. Vista radiográfica e histológica (Experimental 1 mês -Animal 2). Observar formação de tecido ósseo (To) entre as bordas (B) e o espaçador ainda íntegro (S), que está circundado por tecido conjuntivo (Tc). Formação óssea associada à membrana (M) que reveste a dura-máter.

Figura 14. Vista radiográfica e histológica (Experimental 1 mês -Animal 4). Observar que a membrana (M) que recobre o defeito está parcialmente reabsorvida e a que reveste a dura-máter está mais íntegra. Formação de tecido ósseo entrelaçado (To) interposto de tecido conjuntivo (Tc). Notar a formação óssea abaixo da membrana que reveste a duramáter. . .76 
Figura15. Vista histológica (Experimental 1 mês -Animal 4). a) Detalhes da membrana (M) na superfície da dura-máter em contato com o tecido ósseo (To) acima, separada por uma fina camada de tecido conjuntivo (Tc), já exibindo sinais de reabsorção na membrana, principalmente na região das lamelas ósseas secundárias (setas); e b) a membrana (M), interposta entre o tecido ósseo neoformado apresentando pequenas áreas de reabsorção (seta)

Figura 16. Vista histológica (Experimental 1 mês -Animal 4). a). Detalhes da figura anterior exibindo sinais de reabsorção na superfície da membrana (seta) por células mononucleadas. Observar a presença de uma fina camada de tecido conjuntivo (Tc) separando a membrana (M) do tecido ósseo neoformado (To); b) tecido ósseo neoformado apresentando canais preenchidos por tecido conjuntivo (Tc) e hemácias (setas) aprisionado no interior da matriz

Figura 17. Vista histológica (Experimental 1 mês -Animal 4). a) Detalhe da superfície periostal do defeito exibindo tecido conjuntivo (Tc) em íntimo contato com o tecido ósseo (To) neoformado já exibindo características de periósteo; e b)Detalhe da neoformação óssea (To) próximo, à borda do defeito (B)

Figura 18. Vista histológica (Experimental 1 mês -Animal 4). a) Detalhe do tecido ósseo neoformado (To) que preenche a área do defeito com inúmeras hemácias (setas) provenientes do coágulo sangüíneo aprisionadas no interior da matriz óssea; e b) Detalhes da figura anterior da membrana exibindo sinais de reabsorção na superfície (seta) por células mononucleadas. Observar a presença de uma fina camada de tecido conjuntivo (Tc) separando a membrana do tecido ósseo neoformado (To). .80 
Figura 19. Vista radiográfica e histológica (Experimental 1 mês -Animal 5). Observar que a área do defeito está preenchida por tecido conjuntivo (Tc) devido à rápida reabsorção do espaçador. Pequena formação óssea nas bordas do defeito (asterisco). Membrana (M) que recobre o defeito está íntegra, enquanto que a membrana que recobre a dura-máter está parcialmente reabsorvida

Figura 20. Vista radiográfica e histológica (Controle 1mês -Animal b). Observar que a área do defeito está preenchida por fino tecido conjuntivo fibroso (seta). Pequena formação óssea nas bordas do defeito (To).Presença de fragmentos do espaçador (S), sofrendo processo de reabsorção e envolto pelo tecido conjuntivo.

Figura 21. Vista radiográfica e histológica (Experimental 3 meses -Animal 5). Observar a área do defeito preenchido por grandes ilhas de tecido ósseo de arranjo compacto (To) com a presença de restos do espaçador (S) e envolvendo as partículas filetes de tecido conjuntivo (Tc) fibroso .85

Figura 22. Vista histológica (Experimental 3 meses -Animal 5). a) Observar a área do defeito preenchido por grandes ilhas de tecido ósseo de arranjo compacto (To) separadas por uma camada de tecido conjuntivo (Tc) e a presença de fragmentos da membrana da região da dura- -máter (Fm) envolvidas por tecido ósseo (To) neoformado. b) Presença de ilhotas ósseas (To) no centro do defeito, separadas por um tecido conjuntivo denso (Tc) .86

Figura 23. Vista histológica (Experimental 3 meses -Animal 5). a) Observar a presença de restos do espaçador (S) envolvidos por tecido ósseo neoformado (To) e tecido conjuntivo (Tc). b) Vista num aumento maior. Tecido conjuntivo (Tc) denso, separando as ilhotas de tecido ósseo neoformado (To) e inúmeras células aprisionadas no interior da matriz neoformada (seta) 87 
Figura 24. Vista radiográfica e histológica (Experimental 3 meses -Animal 4). Observar a área do defeito preenchido por grandes ilhas de tecido ósseo (To) com a presença de restos do espaçador (S) e envolvendo as partículas filetes de tecido conjuntivo fibroso (setas). Observar a presença da membrana acima do defeito e os fragmentos da membrana (Fm) que revestia a dura-máter associada à formação óssea 88

Figura 25. Vista histológica (Experimental 3 meses -Animal 4). Detalhes da figura anterior: a) Membrana (M) sendo reabsorvida com a presença de formação de ilhotas de tecido ósseo (To) interposta por tecido conjuntivo denso (Tc). Observar a estrutura da membrana com seus canais harvesianos; b) Vista mais próxima da membrana com sinais de reabsorção (setas) e tecido conjuntivo (Tc) invaginado principalmente nas lamelas secundárias

Figura 26. Vista histológica (Experimental 3 meses -Animal 4). a) Presença de fragmentos da membrana $(\mathrm{Fm})$ que recobria a região da dura-máter associada à formação de tecido ósseo (To); e b) Vista mais próxima exibindo osso jovem em contato com fragmentos da membrana .90

Figura 27. Vista histológica (Experimental 3 meses -Animal 4). Detalhe do espaçador (S) sendo reabsorvido associado a neoformação óssea (To) circundado por tecido conjuntivo (Tc) .91

Figura 28. Vista radiográfica e histológica (Controle 3 meses -Animal e). Observar que a área do defeito está preenchida por tecido conjuntivo (Tc). Pequena formação óssea nas bordas do defeito (asterisco). Ausência do suporte. Notar a presença da rede sangüínea logo abaixo do tecido conjuntivo ....92 
Figura 29. Vista radiográfica e histológica (Experimental 6 meses -Animal 3). Observar a área do defeito preenchido por grandes ilhas de tecido ósseo (To) com áreas de medula óssea (Mo) e, envolvendo as partículas, filetes de tecido conjuntivo fibroso (Tc). Observar a presença da membrana (M) acima do defeito e formação óssea associada a restos da membrana que recobria a dura-máter (setas)

Figura 30. Vista histológica (Experimental 6 meses -Animal 3). Detalhes da figura anterior: formação de tecido ósseo (To) abaixo da membrana (M) com tecido conjuntivo fibroso (Tc) ao redor. Observar o processo de reabsorção nas lamelas secundárias da membrana que recobre o tecido ósseo neoformado.

Figura 31. Vista radiográfica e histológica ( Experimental 6 meses -Animal 1). Observar a área do defeito totalmente preenchido por tecido ósseo (To) de arranjo compacto, sendo que na região próxima à borda do defeito (B) já exibe em seu interior canais medulares (Mo). Presença da membrana (M) acima do defeito com uma dobra e formação óssea associada a restos da membrana que recobria a dura-máter (Seta)

Figura 32. Vista histológica (Experimental 6 meses -Animal 2). Detalhes da figura anterior:; a) região apresentando tecido ósseo compacto (To) com vários canais medulares (asterisco); e b) região central exibindo tecido ósseo (To) de arranjo trabecular com canais medulares (Mo). Observar a quantidade de células ósseas já aprisionadas no interior do tecido ósseo neoformado (setas). 97

Figura 33. Vista radiográfica e histológica (Controle 6 meses -Animal c). Observar que a área do defeito está preenchida por tecido conjuntivo (Tc). Pequena formação óssea nas bordas do defeito (To). Notar que o limite do defeito está bem definido, diferenciando visualmente as bordas (B) do tecido ósseo neoformado .98 
Figura 34. Vista radiográfica e histológica (Experimental 9 meses -Animal 1). Observar a área do defeito preenchido por grandes ilhas de tecido ósseo (To) com áreas de medula óssea (Mo) e envolvendo as partículas filetes de tecido conjuntivo fibroso (setas). Notar a formação óssea associada aos fragmentos da membrana $(\mathrm{Fm})$ na região da dura-máter, aumentando a espessura de tecido ósseo na região 100

Figura 35. Vista radiográfica e histológica (Experimental 9 meses -Animal 5). Observar a área do defeito preenchido por grandes ilhas de tecido ósseo (To) com áreas de medula óssea (Mo) e envolvendo as partículas filetes de tecido conjuntivo fibroso (setas). Notar o aumento do tecido ósseo neoformado, e na região da dura-máter o aumento ósseo associados aos fragmentos da membrana (Fm) 101

Figura 36. Vista histológica (Experimental 9 meses -Animal 2). Detalhes da figura anterior: a) formação de tecido ósseo (To) e de medula óssea (M); e b) região central exibindo tecido ósseo (To) de arranjo compacto separados por pequenos filetes de tecido conjuntivo (seta). Notar a quantidade de células aprisionadas no tecido ósseo neoformado 102

Figura 37. Vista radiográfica e histológica (Experimental 9 meses -Animal 2). Observar, neste caso, a área do defeito totalmente preenchido por tecido ósseo (To) de arranjo compacto, sendo que na região próxima a borda do defeito (B) já exibe em seu interior canais medulares (Mo) 103

Figura 38. Vista histológica ( Experimental 9 meses -Animal 2). Detalhes da figura anterior: a) formação de tecido ósseo (To) e de medula óssea (Mo); e b) região central exibindo tecido ósseo (To) de arranjo compacto. Notar a quantidade de células aprisionadas na matriz. 104 
Figura 39. (Vista radiográfica e histológica (Experimental 9 meses -Animal 6). Observar formação óssea nas bordas (To) com fibrosamento central (f) provavelmente devido à rápida reabsorção do espaçador (suporte). fragmentos da membrana (Fm) estão presentes na região da dura-máter associados à formação de tecido ósseo, abaixo das bordas, aumentando a espessura óssea na região. 105

Figura 40. Vista radiográfica e histológica (Controle 9 meses -Animal 1). Observar que a área do defeito está preenchida por tecido conjuntivo (Tc). Pequena formação óssea nas bordas do defeito (To) 106

Figura 41. Vista radiográfica e histológica (Controle 9 meses -Animal 5).Observar pequena formação óssea nas bordas do defeito (To). Osso neoformado, na região central, circundado por tecido conjuntivo fibroso (Tc). 107

Figura 42. Vista histológica (Controle 9 meses -Animal 5). Detalhes da figura anterior. Região de borda (B) com tecido ósseo neoformado (To) e presença de tecido conjuntivo fibroso (Tc) em direção ao centro do defeito 108 


\section{LISTA DE TABELAS}

Tabela 1. Indicações e contra-indicações no uso de membranas não absorvíveis....24

Tabela 2. Dados de membranas disponíveis no mercado 30

Tabela 3. Grupos experimentais avaliados e respectivos períodos de sacrifício......48

Tabela 4. Medidas descritivas da variável Arluc $\left(\mathrm{mm}^{2}\right)$ .69

Tabela 5. Relação das variáveis que foram analisadas . .70

Tabela 6. Resultados da Regressão Linear .71

Tabela 7. Diferença média estimada e limites inferior e superior para os períodos estudados. .72 


\section{Resumo}




\section{RESUMO}

Materiais à base de colágeno têm sido amplamente usados na medicina e odontologia em virtude das suas propriedades biológicas e físicas. A pretensão deste estudo foi de avaliar histológica e morfometricamente o reparo de defeitos de tamanho crítico promovido pela dupla membrana de osso cortical bovino (Gen-derm, 250-300 $\mu \mathrm{m}$ de espessura). Um defeito de $10 \mathrm{~mm}$ de diâmetro foi produzido na calvária de 40 cobaias (“Cavia porcellus”) levando à remoção de ambas as corticais. Em 20 animais, o lado epidural do defeito foi protegido com uma membrana sobre a dura-máter e depois preenchido com coágulo sangüíneo, o lado ectodural foi recoberto com uma segunda membrana. Um suporte de osso alogênico desmineralizado inativado (3 mm de diâmetro) foi usado como mantenedor de espaço. O defeito, no grupo controle, foi preenchido com coágulo sangüíneo e o mantenedor de espaço na região central. Após os períodos de 1, 3, 6 e 9 meses póscirurgia, as calotas foram coletadas, fixadas, radiografadas, processadas para análise histológica através de cortes semi-seriados. Morfométrica e histologicamente o grupo experimental mostrou aumento significativo na neoformação óssea iniciando-se pelas bordas do defeito. No primeiro e terceiro mês , o osso primário ocupava 31,7\% e 59,9\% (versus 21,3\% e 38,6\% do controle), respectivamente, da área do defeito. Em dois casos, nos meses 6 e 9 ocorreu o preenchimento total do defeito com osso lamelar. Nestes dois últimos períodos, o novo osso ocupou 81,9\% e 96,2\% dos 
defeitos, respectivamente, enquanto no grupo controle a média da área do novo osso foi 55,4\% e 45,4\%. A regressão linear múltipla com correção de Bonferroni aplicada nos dados da morfometria radiográfica mostrou uma diferença estatisticamente significante entre os grupos nos períodos de 6 e 9 meses. Os resultados obtidos, neste estudo, indicaram que o uso da dupla membrana de cortical óssea bovina desmineralizada e o mantenedor de espaço promoveram um ótimo reparo do defeito de tamanho crítico em calvária de cobaias. 


\section{INTRODUÇÃO}

A reconstrução de grandes deficiências ósseas é um desafio para cirurgiõesdentistas e ortopedistas. Estas deficiências podem ter várias origens: defeitos faciais congênitos, traumatismos, infecções, pseudo-artrose congênita ou recessão tumoral.

Um dos grandes entraves para o sucesso na reparação dessas deficiências é a invasão da área pelo tecido conjuntivo circunjacente perturbando, ou mesmo, impedindo a regeneração óssea no local. Embora não se conheçam ainda as bases celulares e moleculares dessa interferência na osteogênese, sabe-se que, “in vitro”, os fibroblastos produzem fatores solúveis que inibem a diferenciação de células ósseas e a osteogênese (OGISO et al. ${ }^{86}$, 1991).

SCHMITZ et al. ${ }^{111}$ (1990) relataram que a não união óssea se deve a alterações na diferenciação das células responsáveis pela produção óssea, possivelmente em virtude da ausência de fatores de crescimento e de diferenciação nesses grandes defeitos ósseos.

Na Odontologia, a principal causa de perda de estrutura tecidual é a infecção bacteriana, e conseqüentemente a instalação e progressão da periodontite. Em determinados estágios da doença, pode ocorrer a perda de mais de uma estrutura tecidual, ou seja, do ligamento periodontal, cemento e osso alveolar. Assim, uma das finalidades da Periodontia é a regeneração do suporte periodontal, incluindo-se o ligamento periodontal, cemento e osso.

Nesse sentido, MELCHER ${ }^{74}$ (1976) ressaltou, em uma revisão clássica do potencial regenerativo do periodonto, que as células mesenquimais indiferenciadas presentes no ligamento periodontal têm o potencial de originar células como os cementoblastos e osteoblastos para o restabelecimento da inserção conjuntiva entre o dente e a gengiva, e entre o dente e o osso neoformado. 
Na década de 80, muitos estudos foram realizados sobre a capacidade regenerativa e a dinâmica de reparação do tecido periodontal acometido de doença periodontal corroborando a revisão de $\operatorname{MELCHER}^{74}$ (1976). A capacidade regenerativa das células mesenquimais do ligamento periodontal foi comprovada, em estudos, em animais (KARRING; NYMAN; LINDHE ${ }^{55}$, 1980; NYMAN et al. ${ }^{82}$, 1980).

A formação de um epitélio juncional longo na área em reparo de defeitos periodontais parece ter a finalidade de forrar a superfície radicular e isolá-la do tecido de granulação oriundo do tecido ósseo vizinho à raiz, prevenindo a reabsorção e a anquilose radicular (KARRING; NYMAN; LINDHE ${ }^{55}$, 1980). A formação de nova inserção seria, então, impedida pela maior capacidade proliferativa do tecido epitelial em relação às células do tecido ósseo e do ligamento periodontal (CAFFESSE et al. ${ }^{18}$, 1987).

As técnicas cirúrgicas periodontais tradicionais, como gengivectomia, debridamento em campo aberto, Widman modificado, cuja função principal é proporcionar o melhor acesso às superfícies radiculares com periodontite e a remoção de fatores locais, tais como: placa, cálculo e endotoxinas, resultam em redução da profundidade de sondagem e ganho clínico de inserção (RAMFJORD et al. $\left.{ }^{98}, 1975\right)$; (BECKER; BECKER ${ }^{4}, 1993$ ); (KALDAHL et al. $\left.^{54}, 1996\right)$. Diversos estudos histológicos e histométricos realizados em macacos e humanos (WILDERMAN et al. ${ }^{131}$, 1970; CATON, NYMAN ${ }^{21}$, 1980; CATON, NYMAN, ZANDER ${ }^{22}$, 1980; BOWERS, CHADROFF, CARNEVALE ${ }^{9}$, 1989) mostraram que o ganho de inserção, após estas técnicas cirúrgicas tradicionais, era normalmente resultante da formação de um epitélio juncional longo com pouca ou nenhuma inserção através do tecido conjuntivo e uma formação ínfima de cemento. O tecido epitelial e os tecidos conjuntivos circunjacentes atuam como competidores, através do rápido crescimento e propagação na ferida cirúrgica, inibindo a proliferação e migração de células mesenquimais do ligamento periodontal para a área lesionada e impedindo a formação de novo ligamento periodontal, cemento e osso. 
Na Implantodontia, o requisito obrigatório para a colocação de implantes ósteointegrados é haver quantidade de tecido ósseo suficiente para envolver todo o implante, permitindo sua sustentação quando da colocação da peça protética, absorvendo, diminuindo e, até, eliminando as forças geradas quando este binômio implante-prótese estiver em função.

Nos últimos anos, o princípio da regeneração tecidual guiada (RTG) foi desenvolvido e aprimorado para o tratamento e regeneração de tecidos periodontais perdidos por causa dos processos inflamatórios no periodonto e a regeneração de tecido ósseo em áreas edêntulas que seriam submetidas à colocação de implantes metálicos ósseo-integráveis. Conceitualmente, regeneração é uma situação onde o processo de reparo, após injúria tecidual, culmina com o restabelecimento integral dos aspectos morfológicos e funcionais do tecido (TEN CATE ${ }^{122}$, 1994). O princípio da RTG é utilizar uma barreira física para criar um ambiente adequado, protegido da invasão de células competidoras, menos diferenciadas e altamente proliferativas dos tecidos vizinhos, principalmente fibroblastos e células epiteliais, e promover a proliferação de células originariamente características da região para a regeneração dos tecidos naturais da área (NYMAN et al. ${ }^{82}$, 1980).

O conceito de Regeneração Tecidual Guiada (RTG) para o tratamento de defeitos periodontais foi difundido na década de 1980, sendo a técnica indicada a partir do trabalho publicado por NYMAN et al. ${ }^{84}$ (1982). Os autores avaliaram o potencial regenerativo do ligamento periodontal e das células ósseas através da exclusão do epitélio e tecido conjuntivo do defeito tipo fenestração, por uma barreira mecânica, em incisivos maxilares e caninos mandibulares de macacos. Na maioria dos casos, houve regeneração de ligamento, cemento e osso alveolar, com as fibras do ligamento inserindo-se no cemento e osso neoformados. Em alguns casos, havia a inserção conjuntiva direto na dentina sem a formação de cemento na raiz.

O primeiro relato de um dente tratado seguindo o princípio da RTG foi realizado por NYMAN et al. ${ }^{83}$ (1982) usando uma barreira com um filtro de acetato de celulose. Na 
análise histológica observou-se a presença de nova inserção conjuntiva e novo cemento. Esta nova inserção direcionava-se da crista óssea até uma extensão de 5 mm coronalmente.

As observações de NYMAN $^{83}$ foram corroboradas pelas de GOTTLOW et al. ${ }^{40}$ (1986) em um estudo utilizando 12 dentes de 10 pacientes com grau avançado de periodontite tratados com a técnica de RTG, usando uma membrana teflon como barreira. Um aspecto interessante, neste estudo, é o relato de que as lesões que apresentaram maior regeneração foram as angulares, possivelmente graças à manutenção de um espaço suficiente entre o tecido ósseo e a barreira, favorecendo o repovoamento com células do tecido ósseo.

A viabilidade da RTG, na restauração de lesões ósseas perenes, na espinha dorsal e em corticais de ossos longos, foi demonstrada por HURLEY et al. ${ }^{48}$ (1959) com uma barreira física de filtros semipermeáveis de acetato de celulose (Millipore). Em 1964, BOYNE ${ }^{10}$ obteve regeneração de osso alveolar na região buco-facial com a RTG. LINGHORNE ${ }^{64}$ (1960) mostrou que o tratamento de lesões segmentares de $15 \mathrm{~mm}$ em fíbula de cachorro com um tubo de polietileno preenchido com coágulo sangüíneo e enxerto ósseo medular resultaram na reparação completa da lesão, enquanto no lado controle ocorreu apenas o fibrosamento.

A partir dos trabalhos de NYMAN et al. ${ }^{83}$ (1982) e DAHLIN et al. ${ }^{31}$ (1989) foram definidos os termos RTG, para o tratamento de defeitos periodontais e o de ROG, para defeitos ósseos não periodontais.

A regeneração óssea guiada (ROG) mostrou ter sucesso em uma variedade de experimentos em modelos animais. DAHLIN et al. ${ }^{30}$ (1988) conseguiram o reparo completo de defeitos de tamanho crítico em mandíbulas de ratos, bem como em calvária de ratos (DAHLIN; ALBERIUS; LINDE ${ }^{33}, 1991$ ), apicectomias em macacos (DAHLIN et al. ${ }^{33}$, 1990), na correção de rebordos ou defeitos residuais, em alvéolos após exodontias, em defeitos do tipo deiscência produzidos no ato da instalação de implantes dentais e na recuperação de implantes afetados por periimplantite (WANG; CAROLL ${ }^{128}$, 2001). No entanto, pouco se encontra na literatura sobre os mecanismos fundamentais básicos por trás 
deste conceito. Tem-se declarado que a neoformação óssea desenvolve-se por meio do periósteo e de células derivadas da medula óssea que apresentam potencial osteogênico (BUSER; DAHLIN; SCHENK ${ }^{16}$, 1994).

O efeito da colocação de barreiras mecânicas, na fase inicial de cicatrização da ferida, necessita ser melhor entendido. Tem-se especulado que tal procedimento facilita a seleção das células com potencial osteogênico da população celular dos canais haversianos e de Volkmann e, principalmente, da medula óssea e do endósteo. Neste caso, o periósteo é excluído porque está readaptado na superfície externa da membrana (BUSER; DAHLIN; SCHENK $\left.^{16}, 1994\right)$.

Segundo, BUSER; DAHLIN; SCHENK ${ }^{16}$, (1994) as características desejáveis de uma membrana ideal seriam: a) possuir permeabilidade tal que permita a difusão de plasma e nutrientes, porém não a passagem de células; b) ser biocompatível; c) funcionar como suporte físico ao tecido mole circundante, prevenindo o colapso do espaço necessário para a formação óssea; d) criar e manter um espaço preenchido com coágulo sangüíneo no qual células osteogênicas possam migrar; e) proteger a delicada rede vascular durante a organização do coágulo; f) excluir células não osteogênicas; e g) prevenir a formação da cicatriz tecidual.

A primeira membrana a ser utilizada comercialmente foi a de politetrafluoretileno expandido (e-PTFE), cujos resultados experimentais e clínicos obtidos foram excelentes e, por isso, vem sendo amplamente utilizada na prática cirúrgica (TINTI; VINCENZI; COCCHETTO $^{124}$, 1993; BECKER; BECKER $\left.{ }^{4}, 1993\right)$; CORTELLINI; TONETTI ${ }^{28}, 2000$; KARRING; CORTELLINI ${ }^{56}$, 1999; WANG; CAROLL ${ }^{128}$, 2001). A membrana de e-PTFE é biocompatível, clinicamente manuseável e apresenta excelente propriedade oclusiva, no entanto, não é absorvida pelo organismo, sendo necessária uma segunda intervenção cirúrgica para a sua retirada, causando desconforto ao paciente e podendo interferir na continuidade da reparação tecidual em curso no local (SCOTT et al. ${ }^{112}$, 1997). Este inconveniente impulsionou pesquisas com o intuito de produzir membranas com materiais 
absorvíveis, tais como: o colágeno, o ácido polilático e o ácido poliglicólico. Tais membranas desempenhariam a função de barreira, mas possuiriam vantagens sobre a membrana de e-PTFE, tais como: a) eliminação do segundo ato cirúrgico para a retirada da membrana, b) redução de morbidade geral do tratamento e c) maior conforto ao paciente.

Na clínica odontológica, a membrana absorvível de colágeno é a mais empregada já que o colágeno é uma proteína natural do periodonto e do osso, possui propriedades quimiotáticas e de agregação plaquetária, e sofre reabsorção natural pelo organismo (WANG; MACNEIL ${ }^{127}$, 1998). BUNYARATAVEJ; WANG ${ }^{14}$ (2001) relataram, em sua revisão, que, o emprego das membranas de colágeno, em estudos clínicos, proporcionou resultados semelhantes aos obtidos com membrana de e-PTFE.

A partir da cortical óssea humana desmineralizada é possível obter membranas constituídas principalmente de colágeno tipo I com ótimos requisitos biológicos (SILVERSTEIN; KRAFT; WAND ${ }^{115}$, 1992; CALLAN ${ }^{19}$, 1993; YAMAOKA et al. ${ }^{133}$, 1996). Contudo, a dificuldade de obter osso viável em quantidade, por causa do alto custo e pelo impedimento ético e legal de comercialização de tecidos humanos, no Brasil, tornam este tipo de membrana inviável.

Recentemente, foi introduzida, no mercado brasileiro, uma membrana biológica liofilizada da cortical óssea bovina $\left(\right.$ Gen-derm ${ }^{\circledR}$ ) que se constitui basicamente de fibras colágenas alta e naturalmente estruturadas, cuja utilização, na clínica odontológica, nos casos de lesões ósseas periodontais ou associadas a implantes metálicos osteo-integrados tem sido considerada como sucesso e de alguns trabalhos histológicos em modelos animais já publicados sobre a capacidade osteopromotora desta membrana (TAGA et al. ${ }^{119}$, 1997; TAGA et al. ${ }^{120}$, 2000; HERCULIANI et al. ${ }^{45}$, 2000; SANCHEZ et al. ${ }^{103}$, 2000). Mas, apesar deste relativo sucesso sob critérios clínicos, faltam ainda informações básicas sobre a resposta celular a esta membrana, como por exemplo, o seu tempo de permanência estruturalmente funcional sobre a área de defeito, assim como os mecanismos biológicos locais de sua reabsorção e de estímulo à osteogênese. O conhecimento mais detalhado destas 
informações favoreceria à indicação clínica mais correta e precisa destas membranas para o tratamento de diferentes tipos de lesões.

Deste modo, com o objetivo de esclarecer essas questões pretendemos analisar histológica e radiograficamente o potencial osteopromotor da membrana de osso cortical bovino desmineralizado no reparo de defeito crítico no crânio de cobaias. 
2. Revisão de Literatura 


\section{REVISÃO DE LITERATURA}

O reparo de uma ou mais estruturas teciduais perdidas tem sido um dos grandes desafios para a biologia, tais como: na medicina humana, na veterinária e na odontologia. A reparação da área ferida, na maioria dos casos, pode ocorrer através da substituição da arquitetura do tecido injuriado por outra distinta da original, que se pode conceituar como CICATRIZAÇÃO (WIKESJÖ; NILVÉUS; SELVIG ${ }^{130}$, 1992; TEN CATE ${ }^{122}$, 1994) diferentemente de REGENERAÇÃO onde o processo de reparo, após injúria tecidual, culmina com o restabelecimento integral dos aspectos morfológicos e funcionais (TEN CATE $\left.{ }^{122}, 1994\right)$.

A ausência do reparo, ou o reparo parcial da estrutura, ou função de um tecido, representa para a ortopedia, cirurgia plástica, cirurgia oral e maxilofacial, periodontia e implantodontia uma dificuldade clínica significativa resultando, muitas vezes, em anomalias anatômicas e distúrbios funcionais que, muitas vezes, exigem cirurgias de reentrada (MARDAS; KOSTOPOULOS; KARRING ${ }^{68}$, 2002).

As deficiências ósseas, no esqueleto facial, podem ser causadas por trauma, infecções, ressecção tumoral e defeitos congênitos faciais (DAHLIN; ALBERIUS; LINDE ${ }^{33}$, 1991). Um dos grandes obstáculos para a regeneração em um tecido ósseo injuriado é o crescimento acelerado de tecido conjuntivo e/ou epitelial na área, perturbando, ou impedindo o processo de osteogênese. Isto se deve, primordialmente, a maior taxa de proliferação de fibroblastos destes tecidos que acabam por invadir a área do defeito, interferindo no processo de reparo e prejudicando o processo regenerativo (STAL et al. ${ }^{118}$, 2001). 
Os mecanismos bioquímicos e celulares que explicariam a influência do tecido conjuntivo na osteogênese ainda não estão totalmente desvendados. SCHIMTZ et al. ${ }^{111}$ (1990) analisaram por microscopia de luz e eletrônica de transmissão, o reparo de defeitos ósseos na calvária de ratos com diâmetros de 3, 4, e $8 \mathrm{~mm}$. Os autores relataram que apenas os defeitos de 3 e $4 \mathrm{~mm}$ regeneraram, apresentando maior formação óssea. No defeito de $8 \mathrm{~mm}$, observou-se apenas a formação óssea, na periferia da lesão, enquanto na região central formou-se uma união não óssea de tecido conjuntivo fibroso possivelmente em virtude da carência de fatores ósseos de crescimento e diferenciação não estimulando a diferenciação e maturação de células para produzir e calcificar a matriz óssea.

OGISO et al. ${ }^{86}$ (1991) demonstraram num estudo "in vitro” com células do estroma da medula óssea e fibroblastos do ligamento periodontal de ratos que os fibroblastos sintetizam algumas substâncias solúveis, incluindo-se as prostaglandinas, capazes de inibir a diferenciação de células ósseas e a osteogênese, marcada pela redução da expressão de fosfatase alcalina.

Muitas técnicas cirúrgicas, cujas funções primordiais seriam proporcionar a regeneração morfológica e funcional do tecido perdido, têm sido estudadas, mas poucas atingem o nível de uso clínico rotineiro, em razão do alto custo dos materiais empregados, técnica cirúrgica complexa, necessidade de hospitalização e resultados aquém aos esperados (LINDE et al. ${ }^{63}$ 1993). Um exemplo é o enxerto autógeno de osso fresco em feridas ósseas, ou deformidades resultantes de trauma ou infecção. Apesar de estudos comprovarem bons resultados com esse tipo de enxerto, esta técnica tem algumas desvantagens: a) necessidade de ser realizada em âmbito 
hospitalar; b) maior morbidade do paciente; c) maior nível de reabsorção do enxerto; e d) resultados estão aquém dos esperados.

O princípio da Regeneração Tecidual Guiada foi desenvolvido, nas duas últimas décadas, para a regeneração de tecidos periodontais perdidos resultantes da doença periodontal inflamatória. O tratamento de defeitos ou perdas ósseas pelo mesmo princípio foi conceituado como Regeneração Óssea Guiada (ROG), ou Osteopromoção. O primeiro termo é utilizado principalmente, na área odontológica, enquanto osteopromoção é mais empregado na área de saúde em geral. Iniciou-se, com o trabalho de MURRAY; HOLDEN; ROACHLAU ${ }^{78}$ (1957), que protegeram o coágulo sangüíneo, com um envoltório plástico fenestrado, que se preencheu de osso no fêmur, ílio e coluna espinhal. Os autores concluíram que, para o crescimento do tecido ósseo, eram necessários três fatores: a) presença de coágulo sangüíneo; b) osteoblastos preservados; e c) contato com tecido vivo.

Desde os meados da década de 50, o selamento físico de um sítio anatômico através de barreira mecânica com a função de excluir células não desejáveis da área da ferida e favorecer a proliferação de células específicas para a regeneração tecidual tem sido utilizado na cirurgia reconstrutiva e regeneração neural. Diversos autores utilizaram clinicamente um filtro semipermeável de acetato de celulose (Milipore) para a regeneração de feixes nervosos e tendões (CAMPBELL; BASSET ${ }^{20}$, 1956; ASHLEY; STONE; ALONSO-ARTIEDA et al. ${ }^{1}$, 1959). No mesmo ano, HURLEY et al. $^{48}$ (1959) usaram o filtro de Milipore em cirurgias reconstrutivas de lesões ósseas perenes na espinha dorsal de cães.

A importância da preservação do coágulo sangüíneo foi demonstrada por MELCHER; DREYER ${ }^{73}$ (1964) ,em estudo de reparo de lesões penetrantes, no 
fêmur de ratos, protegidos por barreira plástica. Os autores sugeriram que a função da barreira seria a proteção do coágulo contra a invaginação de células não osteogênicas provenientes dos tecidos adjacentes e a manutenção da estrutura tridimensional original do defeito preenchido pelo coágulo, prevenindo sua distorção pela pressão do tecido. No mesmo ano, BOYNE ${ }^{10}$ mostrou que o uso do filtro de acetato de celulose pôde melhorar o reparo em defeitos no osso alveolar de cães.

O primeiro trabalho relatado sobre o uso de barreira à base de teflon foi o de KAHNBERG $^{53}$, em 1979, para a restauração de defeitos ósseos na mandíbula de coelhos.

O conceito de Osteopromoção ganhou destaque com o trabalho de DAHLIN et al. $^{30}$ (1988), que empregaram a barreira de teflon (e-PTFE) para a regeneração de defeitos ósseos não periodontais. Defeitos de tamanho crítico, ou seja, defeitos que não se regeneram espontaneamente, independente do tempo de vida do animal (SCHIMTZ; HOLLINGER ${ }^{110}$, 1986), foram realizados de cortical a cortical, bilateralmente, nos ângulos da mandíbula de ratos. Um dos defeitos foi recoberto por duas membranas, de maneira que o defeito ficasse entre as membranas, enquanto o defeito contralateral, o controle, não recebeu membrana. A análise histológica mostrou que metade dos animais tratados com as membranas apresentaram regeneração completa do defeito após 3 semanas. Decorridas 6 semanas, a regeneração óssea foi observada em todos os animais tratados com a membrana, enquanto o defeito controle, mesmo após 22 semanas, estava preenchido por tecido conjuntivo fibroso.

DAHLIN et al. ${ }^{32}$ (1990) repetiram o mesmo tipo de defeito trans-ósseo em mandíbulas de macacos e empregaram o mesmo princípio da osteopromoção com 
membranas de teflon expandido (e-PTFE), no seu tratamento, e, além disso, realizaram apicectomias nos incisivos laterais superiores tratados endodonticamente nesses animais criando defeitos tipo cisto. Clinicamente, estes defeitos não apresentaram sinais de regeneração completa, no grupo controle, em virtude da invaginação de tecido conjuntivo para dentro do defeito. Após 3 meses de tratamento em ambos os tipos de defeito, o material teste proporcionou a regeneração óssea completa, enquanto que, no grupo controle, houve formação óssea descontinuada envolta por uma grande massa de tecido conjuntivo. BECKER et al. ${ }^{3}$ (1990) confirmaram histologicamente estes resultados em estudo piloto em cachorros.

NYMAN $^{85}$ (1991) analisou em uma revisão, diversos estudos “in vivo”, a respeito de: defeitos críticos na mandíbula de ratos (DAHLIN et al. ${ }^{30}, 1988$ ), roscas expostas de implantes em tíbias de coelhos (DAHLIN et al. ${ }^{31}$, 1989), defeitos ósseos em forma de túnel em macacos (lesões periapicais com destruição das paredes ósseas corticais lingual e vestibular) que apresentavam reparo incompleto de tecido ósseo (DAHLIN et al. ${ }^{32}$, 1990) e aumento do rebordo alveolar em cachorros (SEIBERT; NYMAN $^{113}$, 1990). Ele concluiu que a aplicação dos princípios da regeneração tecidual óssea para a regeneração de tecido ósseo, apresentou reparo ósseo mais expressivo que no lado controle onde barreiras não foram utilizadas.

DAHLIN; ALBERIUS; LINDE ${ }^{33}$ (1991), num estudo clássico, avaliaram a osteopromoção em defeitos críticos bilaterais de $8 \mathrm{~mm}$ na calvária de ratos, cuidados extremos foram tomados para não injuriar a dura-máter e o cérebro. Seis procedimentos alternativos foram realizados:

1. Recobrimento do defeito no lado ectocranial com uma membrana de ePTFE com diâmetro de 10-11 mm. Reposição do retalho e sutura; 
2. enxerto de pastilhas ósseas com $1 \mathrm{~mm}^{2}$ obtidas do disco de $8 \mathrm{~mm}$ retirado com a trefina. Reposição do retalho e sutura;

3. procedimento $1+2$;

4. membrana de e-PTFE entre a dura-máter e a parte interna do defeito e outra membrana do lado ectocranial;

5. procedimento $2+4$;

6. grupo controle sem membrana e pastilhas ósseas.

Os animais foram divididos em três grupos e sacrificados nos períodos de 3, 6, e 12 semanas. Após o sacrifício, os blocos retirados foram submetidos a processamento histotécnico e coloração por hematoxilina e eosina. Em todos os grupos a regeneração óssea foi similar, exceto nos defeitos controle que estavam preenchidos, principalmente, por tecido conjuntivo frouxo e tecido muscular proveniente da gálea com discreta formação óssea, particularmente, nas bordas. A angiogênese, embora esparsa, era mais intensa nas bordas do defeito. Não houve sinal de manutenção da inflamação ou edema e, no grupo com membrana, apenas algumas células gigantes foram encontradas o que levou os autores a considerarem que as membranas de e-PTFE são bem toleradas. Em alguns casos, houve o colapso da membrana na parte medial do defeito, impedindo a regeneração óssea nesta área (procedimentos 2 e 4). No procedimento onde apenas pastilhas ósseas foram enxertadas, a regeneração óssea foi ínfima. A colocação da barreira sobre estas pastilhas (procedimento 3) não aumentou a capacidade de osteopromoção, a resposta inflamatória, em torno das pastilhas enxertadas, foi baixa. No procedimento onde pastilhas ósseas foram implantadas entre as membranas (Procedimento 5) a regeneração óssea foi mais rápida e substancialmente maior quando comparadas aos 
outros procedimentos. Parece que estas pastilhas funcionaram como um mantenedor de espaço permitindo a expansão do osso a partir das margens. Os autores demonstraram que esta técnica de osteopromoção pode ser de grande valor para a cranioplastia entretanto defeitos maiores em humanos devem ser estudados para comprovar a eficiência da técnica. A técnica descrita acima elimina várias desvantagens de tratamentos prévios aplicados na cranioplastia, tais como: a dificuldade na aplicação, toxicidade e biocompatibilidade.

Estudos clínicos para o aumento de tecido ósseo em implantes (DAHLIN; LEKHOLM; LINDE ${ }^{35}$, 1991) e cobertura de fenestrações em implantes (DAHLIN; ANDERSSON; LINDE ${ }^{34}$, 1991) mostraram a viabilidade da técnica e consagraram o termo osteopromoção. BECKER et al. ${ }^{3}$, (1990) demonstraram que implantes colocados em alvéolos pós-extração de cães preservados com membranas tinham mais tecido ósseo do que o lado controle. Histologicamente, observaram que no lado teste houve a formação de quase $100 \%$ de novo osso em todos os implantes promovendo o recobrimento de todas as roscas expostas do implante. Além disso, houve um aumento significativo na largura do rebordo, no lado teste. No controle pouquíssimo osso formou-se sobre as roscas expostas, o que foi corroborado nos estudos de KNOX; CAUDILL; MEFERT ${ }^{59}$ (1991). Em 1993, BUSER et al. $^{15}$ propuseram o termo “Regeneração Óssea Guiada (ROG)” num estudo clínico de aumento de rebordo anterior à colocação de implantes.

A osteopromoção foi utilizada com sucesso para o aumento da quantidade de tecido ósseo na calvária de ratos (LINDE et al. ${ }^{63}$, 1993). Os autores utilizaram uma membrana rígida em forma de cúpula, com 5 a 8 mm de diâmetro na calvária de ratos, criando um espaço para a migração de células osteogênicas oriundas da 
calvária através do coágulo mantido em posição. A análise histológica no período de 9 a 16 semanas indicou a presença de tecido ósseo neoformado abaixo da cúpula, que chegou a $80 \%$ de seu volume. A quantidade de osso neoformado foi dependente da qualidade da membrana, tipo, porosidade, rigidez e o tempo de reparo. Nos casos onde a membrana não manteve o espaço eficientemente, houve cicatrização por tecido conjuntivo. Este importante trabalho demonstrou que a osteopromoção pode ser um fator de grande valia para a cirurgia reconstrutiva, sendo confirmado posteriormente num estudo em coelhos (ITO; NANBA; MURAL ${ }^{50}$, 1998).

Um estudo comparando diversas membranas absorvíveis em relação à barreira de e-PTFE, em defeitos trans-ósseos na mandíbula de ratos, foi realizado por SANDBERG; DAHLIN; LINDE ${ }^{104}$ em 1993. As membranas absorvíveis eram de ácido poliglicólico e ácido polilático, e possuíam diferentes velocidades de absorção. Concluíram após 12 semanas que estas membranas eram biocompatíveis, causaram uma reação inflamatória superficial de média intensidade, enquanto não foram totalmente absorvidas. Em relação à osteopromoção, não houve diferença significante entre as membranas absorvíveis e a barreira de PTFE. Já entre as membranas absorvíveis, em uma delas a cicatrização do defeito ocorreu mais rapidamente. Notaram, nos estágios iniciais, a presença de tecido cartilaginoso, desaparecendo nos estágios finais.

Em um estudo piloto, COLANGELO et al. ${ }^{25}$ (1993) trataram defeitos transósseos em mandíbula de coelhos com ou sem barreira de colágeno com alta taxa de ligação cruzada e concluíram que no grupo com a membrana havia uma camada completa e contínua de osso lamelar com atividade osteoblástica comparado com um tecido conjuntivo fibroso no grupo controle. No mesmo ano, SEVOR et al. ${ }^{114}$ 
trataram deiscências em implantes com e sem superfície tratada com hidroxiapatita em cachorros com membrana de colágeno. Observaram que o preenchimento do defeito no grupo com a membrana de colágeno foi de $80,29 \%$, aproximadamente o dobro do grupo controle.

SCHENK et al. ${ }^{107}$ (1994) avaliaram o padrão da regeneração óssea em defeitos tratados com membranas de e-PTFE, com ou sem reforço de titânio, na mandíbula de cachorros. Notaram que defeitos do lado controle persistiam, ou seja, a cicatrização óssea foi incompleta. No lado teste, a regeneração óssea e as fases de maturação se mostraram semelhante ao padrão de desenvolvimento e crescimento ósseo. Concluíram que o índice de formação óssea depende da revascularização e do recrutamento de células osteo-progenitoras, e da distância a ser percorrida por estas células, impondo o tempo de permanência durante o qual a membrana deverá ficar funcionalmente intacta no local.

O estudo dos estágios iniciais da cicatrização de defeitos trans-ósseos na calvária de coelhos com barreira de PTFE foram realizados por HÄMMERLE et al. ${ }^{43}$ (1995). A membrana cobriu o defeito e uma extensão de no mínimo 4 mm em osso intacto. As análises foram feitas no período de 2, 3 e 5 semanas. O crescimento ósseo iniciou-se nas bordas do defeito e aumentou com o tempo. Com 1 semana o trabeculado de tecido ósseo cresceu dentro do tecido conjuntivo frouxo altamente vascularizado que ocupava o defeito em direção ao centro. Após 2 semanas, ilhas isoladas de novo osso foram detectadas neste tecido conjuntivo que se uniram em formações maiores. No estágio final, o trabeculado primário do tecido ósseo foi reforçado por depósitos de camadas regulares de osso lamelar, sendo o reparo ósseo caracterizado, segundo os autores, como osso intramembranoso. 
ZAHEDI et al. $^{135}$ (1998) avaliaram o potencial osteopromotor de uma membrana de colágeno bovino tipo I tratada com ligação cruzada por difenilfosforilização em defeito trans-ósseo de tamanho crítico no ramo da mandíbula de ratos. No grupo teste, o defeito foi coberto com a membrana de colágeno por vestibular e lingual. Os animais foram divididos em grupos de 5 e sacrificados após 7, 15, 30, 90 e 180 dias. Antes de 1 mês, a cicatrização foi semelhante nos dois grupos. Com 1 mês, a maioria dos defeitos do lado teste estavam completamente preenchidos com novo tecido ósseo, enquanto que no lado controle encontrou-se uma quantidade limitada de novo osso nas bordas e do lado lingual. Nos animais com 90 e 180 dias, todos os defeitos do lado teste estavam completamente fechados e não houve um aumento estatisticamente significativo no lado controle. Os autores concluíram que a membrana de colágeno bovino com ligação cruzada é biocompatível, tem boas características de manejo na regeneração óssea guiada neste modelo experimental.

MCGINNIS et al. ${ }^{72}$ (1998) compararam cinco tipos de membranas na calvária de cachorros, 3 absorvíveis, fáscia lata congelada e seca, BioMend (colágeno bovino tipo I) e uma membrana de compósitos de ácido poliglicólico e polilático, e entre as membranas não-absorvíveis, politetrafluoretileno expandido (Gore-Tex) e politetrafluoretileno (Milipore). Em cada cachorro foram realizados 5 defeitos de 1,5 cm de diâmetro nos ossos frontal, occipital e parietal, 4 defeitos foram cobertos com um tipo de membrana escolhida aleatoriamente, e um defeito serviu de controle. A análise feita com 10 semanas após a cirurgia, consistiu em mensuração clínica e densitometria radiográfica. Houve fechamento primário para todos os defeitos e não existiram diferenças estatisticamente significantes entre as membranas 
pela densitometria radiográfica. Comparativamente, o crescimento ósseo foi maior na GoreTex e fascia lata, seguida pela BioMend e Milipore e, por último, a membrana de compósito.

HÜRZELER et al. $^{49}$ (1998) relataram que a utilização combinada de membrana de colágeno com hidroxiapatita aumentou significativamente o contato osso-implante quando comparado com a membrana de colágeno sozinha, ou ao defeito, sem a membrana, em macacos. Estes resultados foram confirmados em humanos por ZITZMANN et al. ${ }^{136}(1997)$.

Na calvária de ratos, BOHNING et al. ${ }^{7}$ (1999) relataram que não houve nenhuma diferença entre os defeitos críticos recobertos com uma membrana GUIDOR (compósito) e os defeitos controle sem membrana analisados no período 3, 5 e 7 semanas.

KOSTOPOULOS; KARRING ${ }^{61}$, no ano de 2000, observaram em defeitos críticos na calvária de ratos recobertos com membrana de e-PTFE protegendo o defeito no aspecto cerebral e galeano, a ocorrência da regeneração óssea completa e em mais de $80 \%$ dos espécimes houve a regeneração da sutura sagital.

DUPOIRIEUX et al. $^{37}$ (2001) realizaram um estudo comparativo de 3 membranas: PTFE, de poliglactina e de colágeno oriunda da casca de ovo de aves, em defeitos críticos trans-ósseo de cada lado da calvária de ratos. O defeito teste foi recoberto por uma membrana na parte cerebral do defeito e outra na parte da gálea. Relataram que, para os defeitos recobertos com a membrana de colágeno, houve pouca ou nenhuma osteopromoção e regeneração parcial em apenas um animal dentre 10 casos. Concluíram, neste estudo, que, apenas a barreira de PTFE 
proporcionou resultados favoráveis e sugeriram que a estrutura da membrana é, no mínimo, importante assim como a sua composição.

STAL et al. ${ }^{118}$ (2001) fizeram um estudo na calvária de coelhos com uma membrana absorvível de compósitos (LACTSORB). Relataram que não houve qualquer reação inflamatória com células gigantes tipo corpo estranho e que o defeito coberto, tanto interna como externamente, apresentou resultados mais expressivos que o defeito coberto com apenas uma membrana. Nos dois grupos formou-se uma camada de osso cortical interna e externa e, entre elas, osso medular com tecido adiposo típico. Concluíram que a osteopromoção com membranas absorvíveis é uma terapia alternativa para diminuir defeitos ósseos, após a realização de cirurgias craniofaciais e neurocirurgias, na abóbada craniana, na população pediátrica, em especial nas crianças mais velhas, uma vez que existe a necessidade de uma segunda cirurgia, para fechar estes defeitos residuais da primeira cirurgia.

MARDAS; KOSTOPOULOS; KARRING ${ }^{68}$ (2002) estudaram o impacto da barreira de PTFE e da matriz óssea desmineralizada alogênica na regeneração óssea e da sutura craniana em ratos. Nos defeitos sem tratamento, com 4 meses, houve cicatrização com formação de tecido conjuntivo fibroso na parte medial do defeito, e pequenas porções de novo osso na periferia do defeito. Nos defeitos tratados com osso desmineralizado, alguns casos regeneraram completamente com tecido ósseo ou parcialmente com osso e tecido conjuntivo. Nos casos de regeneração completa com tecido ósseo, foram observadas partículas de osso desmineralizado dando um aspecto compacto ao novo osso gerado. A combinação de membrana e osso desmineralizado promoveram a regeneração completa, mas apenas os defeitos tratados com duas membranas, uma na parte interna e outra na parte externa, regeneraram todo o defeito 
tratado e com a formação de uma estrutura similar à sutura sagital. O contorno da área regenerada nem sempre seguiu o contorno original graças ao colapso da membrana para dentro do defeito. A área regenerada consistia de osso lamelar contendo lacunas com osteócitos e vasos sanguíneos. No tecido similar a sutura, encontraram uma zona de osteoblastos adjacentes ao novo osso formado seguido por uma zona de tecido conjuntivo exibindo alta vascularização. Havia na parte medial da sutura tecido conjuntivo com muitos fibroblastos e fibras orientadas horizontalmente interdigitando entre si, lembrando uma sutura sagital normal.

Atualmente, o princípio da Regeneração Tecidual Guiada e a Osteopromoção baseia-se na utilização de duas classes de barreiras: as absorvíveis e as não absorvíveis. A indicação de que classe de membrana deve ser utilizada, está diretamente ligada ao tipo de defeito escolhido, à relação custo-benefício e a disponibilidade ou interesse do paciente em fazer a cirurgia de reentrada para a remoção da membrana não-absorvível.

As barreiras, quando empregadas na RTG e osteopromoção, devem seguir os seguintes critérios (WANG; MACNEIL ${ }^{127}$, 1998) : a) biocompatibilidade; b) possuir permeabilidade permitindo a difusão de plasma e nutrientes, porém não, a passagem de células; c) atuar como um suporte físico ao tecido mole circunjacente, prevenindo o colapso deste no espaço com o coágulo sanguíneo, onde as células do tecido original da ferida possam migrar; d) proteção da singela rede vascular enquanto o coágulo sofre processo de organização; e) exclusão de células competidoras; f) prevenir a formação de uma cicatriz tecidual; e g) ser de fácil manuseio. 


\subsection{BARREIRAS NÃO ABSORVÍVEIS}

O acetato de celulose foi o primeiro biomaterial a ser utilizado como barreira na RTG. Apesar da obtenção de resultados preliminares favoráveis, este material não possuía os requisitos químicos e estruturais ideais para o uso como barreira à migração epitelial (SALONEN, PERSSON $\left.{ }^{102}, 1990\right)$.

A primeira membrana não absorvível a ser comercializada foi a de politetrafluoretileno expandido (e-PTFE - GORE-TEX). Na década de 80 e 90 muitos estudos clínicos e histológicos comprovaram a sua eficiência e delimitaram as indicações e contra-indicações do uso desta membrana.

As principais indicações na Odontologia no uso de membranas não absorvíveis na Regeneração Tecidual Guiada são descritas na Tabela 1. 
Tabela 1. Indicações e contra-indicações no uso de membranas não absorvíveis.

\begin{tabular}{|c|c|}
\hline INDICAÇÕES & CONTRA-INDICAÇÕES \\
\hline $\begin{array}{l}\text { Defeitos infra-ósseos (BECKER, } \\
\left.\text { BECKER }^{4}, 1993\right) ; \text { CORTELLINI, } \\
\left.\text { TONETTI }^{28}, 2000\right) .\end{array}$ & $\begin{array}{l}\text { Bifurcações classe II (mesial/distal) de } \\
\text { molares maxilares (PONTORIERO, } \\
\text { LINDHE }^{95}, 1995 ; \text { SANZ, } \\
\left.\text { GIOVANNOLI }^{105}, 2000\right) .\end{array}$ \\
\hline $\begin{array}{l}\text { Bifurcações mandibulares classe II } \\
\left.\text { (BECKER et al. }^{2}, 1988\right), \text { MACHTEI; } \\
\text { SCHALLHORN }^{66}, 1995 ; \text { MACHTEI et } \\
\text { al. }^{67}, 1996 ; \text { KARRING; CORTELLINI } \\
\text { 1999). }\end{array}$ & $\begin{array}{l}\text { Bifurcações classe III (PONTORIERO, } \\
\text { LINDHE }^{96}, 1995 ; \text { SANZ, } \\
\left.\text { GIOVANNOLI }^{105}, 2000\right)\end{array}$ \\
\hline $\begin{array}{l}\text { Aumento de rebordo alveolar (BUSER et } \\
\text { al. }{ }^{17}, 1999 \text { ). }\end{array}$ & $\begin{array}{l}\text { Bifurcações de pré-molares (GRAY, } \\
\left.\text { HANCOCK }^{41}, 1998\right) .\end{array}$ \\
\hline $\begin{array}{l}\text { Recessões } \text { gengivais } \text { (CORTELLINI; }^{2} \\
\text { CLAUSER; PINI PRATO }{ }^{27}, \quad 1993 ; \\
\text { TINTI; VINCENZI; } \text { COCCHETTO }^{124} \text {, } \\
\text { 1993). }\end{array}$ & $\begin{array}{l}\text { Perda óssea horizontal (CORTELLINI; } \\
\left.\text { TONETTI }^{28}, 2000\right) .\end{array}$ \\
\hline Sulco palatogengival & $\begin{array}{l}\text { Defeitos infra-ósseos de uma parede } \\
\text { (WANG; CAROLL }{ }^{128}, 2001 \text { ). }\end{array}$ \\
\hline
\end{tabular}

Em relação à Osteopromoção, as indicações estão apoiadas em estudos clínicos e histológicos. Dentre as principais indicações pode-se citar (WANG; CAROLL ${ }^{128}$, 2001): a) correção de deiscências e fenestrações ósseas em implantes; b) implantes imediatos; c) tratamento das seqüelas da periimplantite; d) alvéolos pósextração; e) deficiências locais no rebordo alveolar (horizontal ou vertical limitada), podendo, ou não, ser associado a posterior colocação de implantes (BUSER et al. ${ }^{17}$, 1999); f) defeitos ósseos associados à falha de implantes; g) lesões ósseas residuais; e h) reparo de perfurações na membrana sinusal.

A barreira de e-PTFE possui diversos formatos direcionados para determinado tipo de defeito, além disso, pode-se encontrar esta membrana com 
reforço de titânio utilizada especialmente no aumento de rebordo alveolar. Apesar dos ótimos resultados obtidos com a membrana de e-PTFE, esta possui algumas desvantagens: a) cirurgia de reentrada para a remoção da membrana (LEKOVIC et al. $^{62}$, 1998); b) exposição da membrana no pós-operatório pode comprometer o processo regenerativo (JOVANOVIC; SPIEKERMANN; RICHTER ${ }^{52}$, 1992; MURPHY $^{77}$, 1995; WANG, CAROLL ${ }^{128}$, 2001); c) colonização bacteriana, após a exposição, vai comprometer ainda mais a regeneração da área (NOWZARI, SLOTS $^{80}$, 1995; LEKOVIC et al. ${ }^{62}$, 1998); e d) na remoção da membrana, após 6 meses, o novo osso formado pode reagir à exposição através de reabsorção $\left(\right.$ MURPHY $\left.^{77}, 1995\right)$.

\subsection{BARREIRAS ABSORVÍVEÍS}

As investigações sobre materiais absorvíveis para a confecção de membranas têm como principal objetivo eliminar a cirurgia de reentrada, a qual é um procedimento necessário com barreiras a base de materiais não absorvíveis.

As vantagens de um material absorvível em relação ao não absorvível são (WANG, MACNEIL $\left.{ }^{127}, 1998\right)$ :

1. Materiais biologicamente absorvíveis têm o potencial de: a) resistir ou prevenir a colonização bacteriana; b) aumentar a cobertura ou proteção tecidual e reduzir a exposição da barreira; e c) ter uma maior integração com o tecido hospedeiro;

2. A eliminação da segunda cirurgia para a remoção da barreira permite: a) reduzir o tempo operatório e conseqüentemente reduzir os 
custos; b) reduzir a morbidade do paciente; c) aumentar a aceitação geral do paciente para procedimentos de RTG e Osteopromoção; e d) reduzir os riscos da perda de inserção obtidos pela regeneração devido à cirurgia de reentrada.

As propriedades desejáveis de um material absorvível citadas são (WANG, MACNEIL $\left.^{127}, 1998\right)$ :

1. Atóxica e não antigênica;

2. propriedades de manuseio: a) maleabilidade e resistência; b) preservar e manter espaço; c) adaptabilidade; d) personalizável para situações únicas;

3. aderência;

4. promover a cobertura tecidual e reduzir a freqüência de exposição da barreira;

5. promover a inserção do retalho na cirurgia, reduzindo a incidência de formação de bolsa entre o retalho e a barreira;

6. resistir à germinação e contaminação bacteriana;

7. promover proliferação e migração seletiva dentro do defeito: a) promover preenchimento celular natural ou induzido do defeito por células progenitoras; b) a velocidade de absorção deve permitir a formação do(s) tecido(s) a ser(em) regenerado(s).

As membranas mais relatadas, na literatura, constituem-se de polímeros de ácido polilático e acido poliglicólico e o colágeno, descritos a seguir. 


\subsubsection{Membrana de Ácido Polilático e Ácido Poliglicólico}

A barreira constituída de polímeros é sintetizada a partir da copolimerização de diferentes formas de ácido polilático (PLA) e ácido poliglicólico (PGA), ou uma mistura de ambos. A degradação desta barreira ocorre devido à hidrólise de ligações éster, processo que requer cerca de 30 a 60 dias, dependendo da composição polimérica do material. Devido à quantidade imensa de formulações e variações, há dificuldade na definição de conclusões gerais sobre o seu uso.

Estudos, em modelos animais e clínicos, sustentam que barreiras à base de polímeros de PLA e/ou PGA fornecem resultados comparáveis à membrana de ePTFE (MCGINNIS et al. ${ }^{72}$, 1998; BOHNING et al. ${ }^{7}$ 1999; CORTELLINI TONETTI $^{28}$, 2000; SANZ, GIOVANNOLI ${ }^{105}$, 2000; DUPOIRIEUX et al. ${ }^{37}$, 2001; STAL et al. ${ }^{118}$, 2001) nas técnicas de RTG e Osteopromoção.

\subsubsection{Membranas de Colágeno}

O colágeno tem sido usado para a fabricação de produtos biomédicos devido às suas boas propriedades biológicas e físicas, e também pela ampla disponibilidade. Representa 1/3 de todas as proteínas do corpo. Até o ano de 1995, 19 tipos de colágeno (BROWN, TIMPL ${ }^{11}$, 1995) haviam sido identificados, sendo o colágeno tipo I o mais abundante, cerca de $90 \%$ de todo colágeno do corpo. Atua como principal elemento do tecido conjuntivo, tendo a função de dar suporte estrutural para outros tecidos do corpo. Estruturas como tendões, osso, pele e tecidos periodontais têm grande quantidade de colágeno tipo I. 
As propriedades inerentes ao colágeno são (WANG; CAROLL $\left.{ }^{128}, 2001\right)$ :

a) hemostasia: tem a habilidade de estimular a adesão plaquetária e aumentar a ligação de fibrina, que facilita a formação inicial do coágulo sanguíneo, levando a uma melhor cicatrização e aumentando a regeneração da lesão (WANG et al. ${ }^{126}$, 1978; SABLEMAN ${ }^{100}$, 1985);

b) quimiotaxia: para fibroblastos (POSTLETHWAITE; SEYER; KANG ${ }^{97}$, 1978) do ligamento periodontal (YAFFE; EHRLICH; HOSHAN ${ }^{132}$, 1984) e tecido gengival neutrófilos (CHANG; HOUCK ${ }^{23}$, 1970);

c) fácil manejo: graças à facilidade de manipulação e adaptação, propicia uma das características ideais de material para a RTG, principalmente quando empregada em superfícies radiculares;

d) boa tolerância (MARINUCCI et al. ${ }^{69}, 2001$ ); e: devido à baixa imunogenicidade (TIMPL ${ }^{123}$, 1982; COOPERMAN, MICHAELI ${ }^{26}$, 1984; SABLEMAN ${ }^{100}$, 1985; JOHNS et al. ${ }^{51}$ 1992; SOO; RAHBAR; MOY $^{117}$, 1993; SCHLEGEL et al. ${ }^{108}$, 1997);

e) bioabsorção: por ação de colagenases produzidas por macrófagos e leucócitos polimorfonucleares (CHVAPIL $\left.{ }^{24}, 1981\right)$, o colágeno vai incorporar-se ao retalho, funcionando como um suporte à nova inserção do tecido conjuntivo (COOPERMAN; MICHAELI ${ }^{26}$, 1984), podendo resultar num aumento do tecido e/ou espessura do retalho e proteger o tecido regenerado e impedir futura perda deste tecido;

f) interação com outros tipos celulares, durante a remodelação tecidual e na cicatrização da ferida (KLEINMAN; KLEBE; MARTIN ${ }^{58}$, 1981; GRINNELL $^{42}$, 1982). 
Além das propriedades inerentes ao colágeno, citadas anteriormente, ele possui propriedades que o tornam um biomaterial útil à confecção de uma barreira que são (WANG, MACNEIL $\left.{ }^{127}, 1998\right)$ :

a) Semipermeável, permitindo a passagem de nutrientes e trocas gasosas;

b) suporta a proliferação celular, via estrutura reticular, e domínios para ligação celular;

c) facilita a precoce estabilização e maturação da ferida;

d) promove a migração celular; tem o potencial de promover o fechamento primário, ou reduzir a exposição da barreira;

e) naturalmente absorvível, podendo aumentar o volume tecidual;

g) biocompatível (LOCCI et al. ${ }^{65}$, 1997).

As membranas, em estudo, à base de colágeno, que estão atualmente disponíveis no comércio encontram-se dispostas na Tabela 2 (BUNYARATAVEJ; $\left.\mathrm{WANG}^{14}, 2001\right)$. 
Tabela 2. Dados de membranas disponíveis no mercado.

\begin{tabular}{|c|c|c|c|c|c|}
\hline NoME & FABRICANTE & ORIGEM & $\begin{array}{l}\text { MÉTODO DE } \\
\text { LIGAÇÃO } \\
\text { CRUZADA }\end{array}$ & $\begin{array}{c}\text { PRINCIPAL } \\
\text { COMPONENTE }\end{array}$ & $\begin{array}{c}\text { TAXA DE } \\
\text { REABSORÇÃO * }\end{array}$ \\
\hline BioMend & Sulzer Calcitek, Carlsbad, CA & $\begin{array}{l}\text { Tendão } \\
\text { bovino }\end{array}$ & Formaldeído & $\begin{array}{l}\text { 100\% colágeno } \\
\text { tipo I }\end{array}$ & 6-8 semanas \\
\hline BioMend-Extend & Sulzer Calcitek, Carlsbad, CA & $\begin{array}{l}\text { Tendão } \\
\text { bovino }\end{array}$ & Formaldeído & $\begin{array}{l}\text { 100\% colágeno } \\
\text { tipo I }\end{array}$ & 18 semanas \\
\hline Periogen & Collagen Inc,. Palo Alto, CA & $\begin{array}{l}\text { Derme } \\
\text { bovina }\end{array}$ & Glutaraldeído & $\begin{array}{c}\text { Colágeno tipo I e } \\
\text { III }\end{array}$ & 4-8 semanas \\
\hline Paroguide & Coletica, Lion, França & $\begin{array}{l}\text { Pele de } \\
\text { bezerro }\end{array}$ & Difenilfosforilação & $\begin{array}{l}\text { 96\% colágeno tipo } \\
\text { I e } 4 \% \text { sulfato de } \\
\text { condroitina }\end{array}$ & 4-8 semanas \\
\hline Biostite & Coletica, Lion, França & $\begin{array}{l}\text { Pele de } \\
\text { bezerro }\end{array}$ & Difenilfosforilação & $\begin{array}{l}\text { hidroxiapatita, } \\
\text { 9,5\% colágeno tipo } \\
\text { I, 2,5\% de sulfato } \\
\text { de condroitina }\end{array}$ & 4-8 semanas \\
\hline Bioguide & Geistlich, Wolhusen, Suécia & $\begin{array}{l}\text { Derme de } \\
\text { porco }\end{array}$ & Nenhum & $\begin{array}{l}\text { Colágeno tipo I e } \\
\text { III }\end{array}$ & 24 semanas \\
\hline Tissue Guide & Koken Co., Tóquio, Japão & $\begin{array}{l}\text { Derme } \\
\text { bovina + } \\
\text { tendão }\end{array}$ & $\begin{array}{l}\text { Hexametilenediiso } \\
\text {-cinato }\end{array}$ & $\begin{array}{l}\text { Atelocolágeno + } \\
\text { colágeno de tendão }\end{array}$ & 4-8 semanas \\
\hline BioBar & $\begin{array}{l}\text { Colbar Research \& Dev. Ltd., } \\
\text { Ramat- Hasharon, Israel }\end{array}$ & $\begin{array}{l}\text { Tendão } \\
\text { bovino }\end{array}$ & Sem informação & $\begin{array}{l}\text { 100\% colágeno } \\
\text { tipo I }\end{array}$ & 6-8 semanas ${ }^{*}$ \\
\hline
\end{tabular}

${ }^{*}$ Dados fornecidos pelos fabricantes 
O colágeno, usado na medicina e odontologia, provém de várias estruturas, principalmente de animais e algumas, humanas, onde se incluem a pele, o tendão, os intestinos de boi e carneiro, a derme de porco, a pele e o pericárdio de bezerro. Os procedimentos de isolamento e purificação envolvem a digestão enzimática do colágeno solúvel, ou a extração química de colágeno fibrilar de tecido colagênico, seguida de processamento para a obtenção de géis, esponjas, filamentos, membranas, dependendo da aplicação. O processamento tem a função de rearranjar as fibras colágenas, de forma a diminuir a absorção de água, solubilidade, suscetibilidade a degradação enzimática e imunogenicidade e aumentar a força de tensão e o tempo de biodegradação (PACHENCE $\left.{ }^{88}, 1996\right)$.

Deste modo, a membrana tratada terá maior resistência à absorção por degradação enzimática, e sua integridade estrutural será mantida por mais tempo, para que permita a fixação e proteção inicial do coágulo, e a proliferação de células específicas para a regeneração, que, por conseqüência vai maximizar o processo de regeneração na área da ferida (PITARU et al. ${ }^{93}$, 1988).

O rearranjamento das fibrilas colágenas é feito através de técnicas de ligação cruzada, que pode ser obtido de diversas maneiras (PITARU et al. ${ }^{93}, 1988$ ): a) luz ultravioleta; b) dexametilenodiisocianato; c)glutaraldeído + irradiação ultravioleta; e d) difenilfosforilização.

A manutenção da integridade estrutural da membrana, durante o período inicial do reparo da ferida, é um pré-requisito importante na RTG e Osteopromoção para a manutenção do espaço, e conseqüente repovoamento da área por células originárias do(s) tecido(s) do defeito. A integridade estrutural depende diretamente da taxa de degradação do colágeno, que é influenciada pela origem do colágeno 
empregado. A avaliação da taxa de degradação de vários tipos de colágeno tais como: fascia lata, fascia temporalis e dura-máter humanas e de origem bovina foi estudada por UNSAL et al. ${ }^{125}$ (1997) no subcutâneo dorsal de ratos. As membranas reabsorvidas mais rapidamente foram as do colágeno tipo I de origem bovina e a fascia lata.

OWENS, YUKNA ${ }^{87}$, em 2001, observaram a reabsorção de 3 membranas de colágeno (BIOGUIDE - bovina, ALLODERM - suína e ALLODERM - humana) no palato de cachorros. Relataram que a reabsorção completa aconteceu dentro de 4 meses, variando a taxa de reabsorção dentre os tipos estudados, sem nenhum sinal de inflamação.

Um pré-requisito de uma membrana não absorvível é a sua manutenção no local por 4 a 6 semanas antes de ser removida para não influir nos processos moleculares e celulares envolvidos com a regeneração. Conseqüentemente, as membranas de colágeno teriam que permanecer íntegras, durante esse tempo, para não prejudicarem o processo regenerativo, que pode ser obtido com as técnicas de ligação cruzada que aumentam o tempo de permanência da membrana.

Membranas à base de colágeno, com ligações cruzadas, obtidas de tendão da cauda de ratos, foram utilizadas no tratamento de defeitos criados cirurgicamente em cachorros. PITARU et al. ${ }^{93}$ (1988) observaram a regeneração parcial de novo osso, ligamento periodontal e cemento na metade apical, e inserção tecidual na parte coronal. Nos sítios tratados apenas com a raspagem em campo aberto, observou-se epitélio juncional longo e uma ínfima formação de osso. O tempo de absorção da membrana foi de 4 semanas. Acreditam os autores que a regeneração parcial foi em 
razão da exposição precoce da membrana, favorecendo a sua degradação com mais rapidez.

As diferenças, na velocidade de degradação em alguns estudos, são devidas aos métodos e meios utilizados, tais como: o tipo de sítio de implantação do material analisado (intramuscular ou subcutâneo versus intra-oral), o tipo de ambiente (fechado ou aberto) e se o colágeno sofreu processamento para ligação cruzada. Desta forma, é possível explicar as diferenças relatadas por PAUL et al. ${ }^{92}$ (1992) que examinaram a degradação do colágeno de origem bovina sem ligação cruzada, em defeitos de bifurcações classe II, em humanos; e PITARU et al. ${ }^{93}$ (1988) que implantaram colágeno sem ligação cruzada no subcutâneo e região intramuscular de cachorros. Outro fator que deve ser levado em consideração é que PAUL et al. ${ }^{92}$ (1992) intencionalmente expuseram a parte coronal da membrana, permitindo a colonização bacteriana. Há relatos de que algumas bactérias são capazes de produzir colagenase (Porphyromonas gingivalis, Bacteriodes melaninogenicus), resultando na degradação antecipada da membrana e influindo nos dados finais (MAYRAND, GRENIER $^{71}$, 1985; HEATH et al. $\left.{ }^{44}, 1987\right)$.

A taxa de ligação cruzada empregada parece influenciar nos resultados da Regeneração Tecidual Guiada e Osteopromoção. MINABE et al. $^{76}$ (1989) compararam membranas de colágeno com e sem ligação cruzada, demonstrando que com ligação cruzada, eles obtiveram resultados mais expressivos em termos de biocompatibilidade e inibindo a proliferação do epitélio em direção à ferida. Observaram resíduos da membrana de colágeno tratada com ligação cruzada com 14 dias, enquanto que as não tratadas desapareceram no intervalo de 5 a 7 dias após a implantação. Os autores relataram a rápida proliferação epitelial do $3^{\circ}$ ao $5^{\circ}$ dia, que 
se estendeu até o $14^{\circ}$ dia no grupo teste com colágeno sem ligação cruzada. Enquanto que a taxa de proliferação do epitélio aumentou muito pouco até o $5^{\circ}$ dia, com nenhum crescimento subseqüente, no grupo teste com colágeno tratado com a técnica de ligação cruzada. KODAMA et al. ${ }^{60}$ (1989) quando avaliaram o efeito da taxa de ligação cruzada, na membrana de colágeno em ratos, obtiveram resultados semelhantes ao de MINABE ${ }^{76}$. BUNYARATAVEJ; WANG ${ }^{14}$, em 2001, postularam que o período em que a membrana de colágeno permanece intacta é suficiente para impedir a migração apical do epitélio, durante a fase inicial da cicatrização do defeito periodontal, desde que o tempo crítico para a proliferação epitelial ocorra dentro dos primeiros 14 dias. Corroborando estes estudos, NUMABE et al. ${ }^{81}$ (1993), através de auto-radiografia com ${ }^{3} \mathrm{H}$-timidina, estudaram o processo cicatricial de feridas periodontais em ratos com e sem membrana de colágeno, observando que no grupo teste, células marcadas com ${ }^{3} \mathrm{H}$-timidina estavam nas camadas basal e espinhosa do novo epitélio sulcular, comparado a uma camada única de células marcadas com ${ }^{3} \mathrm{H}-$ timidina sobre a superfície radicular no grupo não tratado com membrana. Não houve extensão apical do epitélio abaixo da junção cemento-esmalte no grupo com a membrana de colágeno mesmo com a sua reabsorção completa no $14^{\circ}$ dia. A membrana de colágeno diminuiu a atividade mitótica da camada basal, resultando no empilhamento das células em divisão adjacente à membrana, inibindo assim, a migração apical do epitélio, favorecendo a aceleração da reinserção conjuntiva e mostrando a capacidade de barreira do colágeno.

BRUNEL et al. ${ }^{12}$ (1996) relataram que, em defeitos em calvárias de ratos, houve um aumento de mais de 4 vezes na formação de tecido ósseo quando da utilização de barreiras com várias taxas de ligação cruzada comparada com 
membranas sem ligação cruzada. Contudo não houve diferença estatística na regeneração óssea nos sítios tratados com as membranas de colágeno com diferentes taxas de ligação cruzada. Sendo assim, os autores concluíram que, uma barreira que apresente longo período de reabsorção, nem sempre proporciona maior regeneração periodontal ou óssea.

Comparando membranas de colágeno com alta e baixa taxa de ligação cruzada, e barreira de politetrafluoretileno em defeitos periodontais circunferenciais, CRIGGER et al. ${ }^{29}$ (1996) relataram que o maior ganho de inserção foi quando da utilização de colágeno com baixa taxa de ligação cruzada e absorção rápida, seguida de barreira de PTFE, e por último, a membrana de colágeno com alta taxa de ligação cruzada e absorção lenta. O baixo ganho de inserção da membrana com alta taxa de ligação cruzada foi por causa da não integração desta com os tecidos circunjacentes onde clinicamente, os autores observaram uma alta taxa de exposição desta membrana e alto índice de recessão gengival onde foi empregada.

Barreiras de colágeno tipo I originadas de pericárdio de bezerros e ligação cruzada com difenilfosforilação proporcionam reação inflamatória significante, sendo reabsorvidas em 2 semanas (MILLER et al. ${ }^{75}$, 1996). Clinicamente, relatos sugerem que esta membrana é efetiva na regeneração tecidual guiada (BENQUÉ et al. $^{5}$, 1997; PARODI; SANTARELLI; CARUSI ${ }^{91}$, 1998). Em modelo animal, o resultado foi contrário aos relatos clínicos, os autores concluíram que mesmo com uma baixa taxa de absorção, obtida através de ligação cruzada, houve pouca ou nenhuma regeneração com a membrana de pericárdio. Já membranas, à base de politetrafluoretileno e de colágeno de pericárdio com alta taxa de absorção (baixa taxa de ligação cruzada), proporcionaram resultados semelhantes de regeneração. 
No uso de barreiras, à base de colágeno proveniente de material bovino, uma preocupação seria a transmissão da encefalopatia espongiforme bovina, mas um painel da US Food and Drug Administration determinou que os materiais à base de colágeno são seguros para o uso, permitindo a aprovação de produtos derivados de colágeno.

O colágeno obtido da dura-máter de cadáveres apresenta uma rede irregular de fibras colágenas e tem sido estudado como barreira na RTG e osteopromoção. Relatos clínicos sugerem que a dura-máter tem um potencial limitado para a regeneração periodontal, corroborado com observações histológicas de biópsias humanas que sugeriram uma baixa integração tecidual (2 semanas), capacidade de inibir a migração apical de tecido epitelial e baixa resposta inflamatória (GARRETT; MARTIN; EGELBERG ${ }^{39}$, 1990; YUKNA ${ }^{134}$, 1992). O uso de dura-máter oriunda de cadáveres pode representar um risco em adquirir a doença de Creutzfeldt-Jakob, não somente para o receptador (MARTINEZ-LAGE et al. $^{70}$, 1994), mas também ao operador (WEBER et al. ${ }^{129}$, 1993). O risco de transmissão é muito baixo, e se houver o processamento e a esterilização corretos, a probabilidade de contágio é muito pequena (NATIONAL INSTITUTE OF NEUROLOGICAL DISORDERS AND STROKE $\left.{ }^{79}\right)$.

Membranas preparadas de osso cortical, com processamento equivalente aos enxertos de osso desmineralizado liofilizado, foram utilizadas em defeitos de bifurcação em conjunto com um enxerto particulado de osso desmineralizado liofilizado e comparado com a membrana não absorvível (e-PTFE). A despeito de existirem poucas informações sobre os aspectos microscópicos desse processo, os autores verificaram que a regeneração foi semelhante para os dois tipos de 
membrana, apesar de considerarem a membrana preparada de osso cortical de difícil manuseio (SCOTT et al. ${ }^{112}$, 1997).

Além da técnica de ligação cruzada, sulfato de heparina e fibronectina têm sido conjugadas à membrana de colágeno na tentativa de aumentar o efeito inibitório na migração epitelial. Um desses estudos comparou a extensão das superfícies radiculares repovoadas por tecido conjuntivo em sítios tratados com apenas a membrana de colágeno e as tratadas com fibronectina e sulfato de heparina. Nos sítios com sulfato de heparina, fibronectina e membrana de colágeno, houve um repovoamento de $30 \%$ a mais nas superfícies radiculares do que no grupo que foi tratado apenas com a membrana de colágeno (PITARU et al. $\left.^{94}, 1991\right)$.

Na Regeneração Tecidual Guiada, a membrana de colágeno tem sido testada clinicamente e em modelos animais, desde a década de 80, em defeitos infra-ósseos (CORTELlini; $\quad$ TONETTI $^{28}$, 2000; BUNYARATAVEJ; WANG ${ }^{14}, \quad$ 2001). BUNYARATAVEJ; WANG ${ }^{14}$ (2001) relataram que, na maioria dos estudos comparativos com membrana de colágeno e debridamento em campo aberto, o grupo, com membrana, mostrou uma redução de profundidade de sondagem, ganho clínico de inserção, preenchimento ósseo significativo em relação ao debridamento feito com cirurgia a retalho.

TANNER et al. ${ }^{121}$ (1988), ao contrário, relataram que não perceberam nenhuma diferença no ganho de inserção clínica, quando comparado à membrana de colágeno com o debridamento com retalho. Provavelmente este resultado obtido foi influenciado pelo número de pacientes tratados, apenas 4, e, além disso, os resultados clínicos foram alcançados em apenas 3 meses pós-tratamento. 
A Regeneração Óssea Guiada mostrou ter sucesso em uma variedade de experimentos em modelos animais. No entanto, pouco se encontra na literatura sobre os mecanismos fundamentais básicos por trás deste conceito. Tem-se declarado que a neoformação óssea se desenvolve por meio do periósteo e de células derivadas da medula óssea que apresentam um potencial osteogênico (BUSER; DAHLIN; SCHENK $\left.^{16}, 1994\right)$.

O efeito da colocação de barreiras mecânicas, na fase inicial de cicatrização da ferida, necessita ser melhor entendido. Tem-se especulado que tal procedimento facilita a seleção das células com potencial osteogênico da população celular dos canais haversianos e de Volkmann e, principalmente, da medula óssea e do endósteo. Neste caso o periósteo é excluído porque está readaptado na superfície externa da membrana (BUSER; DAHLIN; SCHENK ${ }^{16}$, 1994).

Na Odontologia, especificamente na área de Implantodontia, a osteopromoção tem sido empregada no aumento de tecido ósseo para deficiências do rebordo ou inadequada altura/espessura do tecido ósseo no rebordo alveolar. O material utilizado, na regeneração óssea guiada, deve preencher os seguintes requisitos: estabilização e proteção do coágulo, criação e manutenção de espaço e a habilidade de excluir células competidoras do tecido original. A membrana de colágeno, como foi visto anteriormente, preenche todos estes requisitos e por isso tem sido usada como barreira na Osteopromoção. Apesar de nenhum estudo ter definido o tempo necessário para barreiras empregadas na Regeneração Tecidual Guiada, sabe-se que a migração das células ósseas e do ligamento periodontal em procedimentos de RTG atingem o pico máximo entre o segundo e o sétimo dia após a cirurgia, diminuindo a sua atividade mitótica a níveis quase normais ao final da 
terceira semana MINABE et al. $^{76}$ (1989). Entende-se, então, que as células necessárias ao processo regenerativo chegam ao sítio por volta da terceira à quarta semana e como a membrana de colágeno se mantém íntegra, durante este tempo, as barreiras à base de colágeno são suficientes para permitir o repovoamento seletivo de células do defeito em questão.

Estudos em modelos animais e em humanos têm sido amplamente relatados na literatura com sucesso na ROG (COLANGELO et al. ${ }^{25}$, 1993; SEVOR et al. ${ }^{114}$, 1993; PARODI et al. ${ }^{90}$, 1996; DONGIEUX et al. ${ }^{36}$, 1998). Estudos comprovaram que o uso de enxertos ósseos para a criação e manutenção de espaço tende a melhorar os resultados na ROG (ZITZMANN et al. ${ }^{136}$, 1997; HÜRZELER et al. ${ }^{49}$, 1998; BENQUÉ et al. ${ }^{6}$, 1999); HOCKERS et al. ${ }^{46}$, 1999; BRUNEL et al. $^{13}$, 2001; ZITZMANN et al. ${ }^{137}$, 2001).

Estes relatos destacaram uma dificuldade quando da utilização de membranas não absorvíveis, graças à alta incidência de deiscências, exposição da membrana, e/ou remoção prematura da membrana. Isto causa um impacto negativo na quantidade de osso regenerado pela ROG. SIMION et al. ${ }^{116}$ (1994) observaram que barreira de PTFE, quando exposta, proporcionou um ganho bem menor de tecido ósseo quando comparadas com sítios onde a membrana não foi exposta $(41,6 \%$ contra 96,6\%). Por causa destes fatores, em relação ao processo de reparo, os autores mencionados observaram que a membrana de colágeno é superior às não absorvíveis.

Sabe-se que, a matriz óssea de colágeno estruturada, funciona como um ótimo substrato para o recrutamento e ancoragem de células progenitoras, e conseqüentemente na sua proliferação e diferenciação em osteoblastos, podendo servir como proteção para as proteínas morfogenéticas ósseas contra enzimas 
proteolíticas não específicas, características estas que podem ser uma vantagem adicional para a sua aplicação na terapia periodontal e na regeneração óssea (RIPAMONTI; REDDI $\left.{ }^{99}, 1994\right)$.

Então da cortical óssea humana, podem ser obtidas membranas com requisitos biológicos ótimos (SILVERSTEIN; KRAFT; WAND ${ }^{115}$, 1992; CALLAN $^{19}$, 1993; YAMAOKA et al. ${ }^{133}$, 1996), mas o uso deste tipo de membrana é pouco acessível por seu elevado custo e pela dificuldade de obtenção de osso viável em quantidade suficiente.

O relato clínico de FUGAZZOTTO ${ }^{38}$ (1995) utilizando lâminas de osso com espessuras de 100 a $300 \mu \mathrm{m}$ para o aumento de rebordo, em conjunto com a colocação de implantes, proporcionou uma regeneração óssea significativa e sem complicações. O tecido duro, em foco, esteve em função por mais de 32 meses sem qualquer sinal clínico de fracasso.

O uso de lâminas ósseas alógenas comparadas com a membrana de e-PTFE foi avaliado clinicamente por YAMAOKA et al. ${ }^{133}$ (1996) que não observaram diferença entre os dois materiais, na avaliação dos parâmetros clínicos, e nenhum deles mostrou-se melhor.

SCOTT et al. ${ }^{112}$ (1997), em estudo clínico para tratamento de bifurcações classe II mandibulares, compararam membranas de e-PTFE e $\mathrm{LAMBONE}^{\S 1}$. O DFDBA (aloenxerto de osso desmineralizado liofilizado) foi implantado em todos os defeitos e recoberto por um dos dois tipos de membrana. Mensurações clínicas (recessão gengival, profundidade de sondagem, nível de inserção, dimensão dos defeitos) foram realizadas antes e após o procedimento. Não houve diferença

\footnotetext{
${ }^{\S}$ Laminar bone. LifeNet. Inc., Virginia Beach. VA.
} 
estatística entre a membrana de e-PTFE e do LAMBONE. Ambas proporcionaram aumento no preenchimento ósseo vertical e horizontal. Os autores sugeriram que estes dois materiais podem ser equivalentes, quando usados em conjunto com DFDBA, sendo que a LAMBONE não precisa de segundo estágio clínico para a sua remoção.

KASSOLIS; BOWERS ${ }^{57}$ (1999) avaliaram a viabilidade de regeneração óssea supracrestal em pacientes com aloenxertos de osso desmineralizado liofilizado. na forma de partículas, usando como barreiras lâminas e tirantes da cortical de osso (ossos longos) desmineralizado. Concluíram que as lâminas e tirantes de cortical de osso desmineralizado, em várias espessuras, proporcionaram sucesso na regeneração supracrestal dos defeitos horizontais quando combinados com partículas de osso desmineralizado.

Recentemente, foi introduzida, no mercado brasileiro, uma membrana biológica liofilizada de cortical óssea bovina $\left(\mathrm{Gen}-\mathrm{derm}^{\circledR}\right)$, que se constitue, basicamente, de fibras colágenas ósseas, cuja utilização na clínica odontológica, nos casos de lesões ósseas periodontais, ou associadas aos implantes metálicos ósseointegrados tem sido considerada um sucesso . Apesar deste relativo sucesso, na área clínica, faltam ainda informações básicas sobre esta membrana, para que haja uma melhor indicação no tratamento de diferentes tipos de lesões teciduais, como por exemplo, o seu tempo de permanência estruturalmente funcional sobre a área de defeito, assim como os mecanismos biológicos locais que levam à sua total reabsorção pelo organismo e ao estímulo a osteogênese.

Um dos principais modelos utilizados para estudar a Osteopromoção, em animais, é o defeito de tamanho crítico. Conceitualmente seria o menor defeito ósseo 
num osso característico e espécie de animal que não irá reparar espontaneamente durante a vida do animal. (SCHIMTZ; HOLLINGER ${ }^{110}$, 1986).

O tecido ósseo possui características de rigidez e resistência, mas com alta capacidade de regeneração espontânea quando lesionado. Dependendo da dimensão da lesão ocorre a sua regeneração óssea espontânea formando novo tecido ósseo e culminando com o restabelecimento integral dos seus aspectos morfológicos e funcionais (TEN CATE $\left.{ }^{122}, 1994\right)$.

Quando a lesão óssea exceder uma certa dimensão, conceituada como “tamanho crítico”, a sua capacidade regenerativa não conseguirá fechar o defeito como um todo, após tratamento terapêutico convencional, resultando em um defeito ósseo perene. A não formação de novo tecido ósseo, nesta região, é devido à rápida invasão e preenchimento da área por células altamente proliferantes de origem não óssea vindas de tecidos conjuntivos circunjacentes (SCHIMTZ; HOLLINGER ${ }^{110}$, 1986).

Os estudos em modelos animais produzem informações importantes sobre diversas substâncias e métodos utilizados para estimular a formação óssea. Porém, a extrapolação dos resultados obtidos em animais, para os humanos, deve ser feita com cuidado, pois normalmente esses animais possuem um potencial regenerativo maior do que os humanos (BOSCH; MELSEN; VARGERVIK ${ }^{8}$, 1998). 


\section{Proposição}




\section{PROPOSIÇÃO}

O objetivo geral deste trabalho é analisar as caracteristicas microestruturais da membrana de osso cortical bovino desmineralizada através da microscopia de varredura, e, histológica e radiograficamente, analisar o potencial osteopromotor da membrana de osso cortical bovino desmineralizada em defeito crítico no crânio de cobaias.

Especificamente pretende - se:

- Avaliar a possibilidade da utilização do defeito crítico em crânio de cobaias como modelo experimental para o estudo de reparo ósseo;

- determinar o numero de poros / $\mathrm{mm}^{2}$ e o diâmetro médio destes poros da membrana de osso cortical bovino desmineralizada;

- descrever as caracteristicas das imagens radiográficas durante o reparo do defeito crítico no grupo controle e experimental;

- padrão de fechamento do defeito através da quantificação de área radiolúcida (Arluc);

- analisar estatisticamente a área radiolúcida versus o tempo (períodos experimentais).

- descrever os elementos celulares e a osteogênese durante o reparo do defeito crítico no crânio de cobaias. 


\section{Material e Métodos}




\section{MATERIAL E MÉTODOS}

As membranas (Gen-derm ${ }^{\circledR}$, registro no MS 103.455.00007) foram doadas pela Baumer S.A., fabricante da membrana de osso cortical bovino desmineralizada e liofilizada (Figura 1).

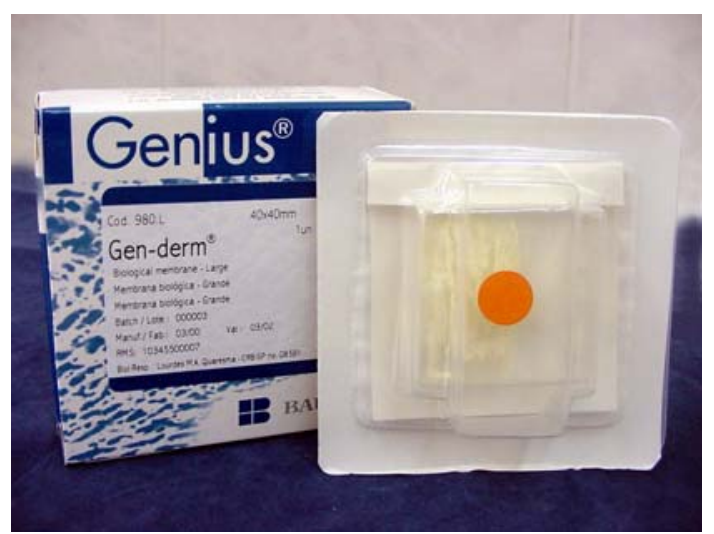

Figura 1: Embalagem e membrana Gen-Derm.

\subsection{ANÁLISE MICROESTRUTURAL DA MEMBRANA}

A análise microestrutural da membrana de cortical óssea bovina liofilizada foi realizada no Núcleo de Apoio à Pesquisa em Microscopia Eletrônica Aplicada à Pesquisa Agropecuária (NAP/MEPA) - ESALQ-USP, administrado pelo Prof. Elliot Watanabe Kitajima. Para tanto, foram obtidos fragmentos de $5 \mathrm{~mm}^{2}$ de uma amostra composta por 3 membranas de cortical óssea bovina liofilizada, armazenadas em embalagens estéreis originais. Os fragmentos foram dispostos horizontal e verticalmente no porta espécime “stub” e levados ao metalizador “sputtering” (MED 010 da Balzers), onde foi realizada a deposição de fina camada de ouro (100-200 Å). 
As amostras foram analisadas em um microscópio de varredura Zeiss DMS 910A. As imagens foram capturadas pelo software DITI (Carl Zeiss) em aumentos variados e armazenadas no formato "Bitmap do Windows” ( bmp).

\subsection{PREPARO DO ESPAÇADOR}

É um bloco de osso alogênico desmineralizado inativado medindo 3x3x3 mm cuja função é a de manter as membranas no local apropriado (Figura 2) e servir como suporte, até que o coágulo se organize, e haja tempo suficiente para a sua substituição por tecido ósseo primário proveniente de células ósseas da margem do defeito.

O espaçador para ser utilizado, em cada defeito cirúrgico, foi obtido de ossos parietais de 3 animais doadores (Cavia porcellus). Após serem coletadas as peças, foi lavado vigorosamente cada osso, e foi resfriado a uma temperatura de $18^{\circ} \mathrm{C}$. Em seguida, as peças foram processadas, segundo a técnica de Urist, Mikulski e Boyd (1975) para a obtenção da matriz óssea desmineralizada inativada (sem potencial osteoindutor). O protocolo seguido foi:

a) Descalcificação em solução de ácido clorídrico a 0,6M (6ml da solução/peça), com controle radiográfico, a cada 2 horas, até a desmineralização completa;

b) inativação do potencial osteoindutor da matriz óssea desmineralizada, em solução de cloreto de guanidina 4M para retirada das BMPs, com trocas periódicas, e monitoramento por leitura espectrofotométrica (280 nm) de alíquotas da solução antes de cada troca; 
c) neutralização em solução fisiológica estéril (cloreto de sódio a 0,9\%), após mais ou menos 8 horas do início da descalcificação;

d) remoção dos restos de medula e sangue, com o auxílio de uma agulha hipodérmica, seguida de banho de água;

e) fragmentação em hastes de aproximadamente $3 \mathrm{~mm}$ de diâmetro (para serem usadas como espaçador);

f) armazenagem em solução de etanol, à $70 \%$.

\subsection{PREPARO DOS ANIMAIS E PROCEDIMENTOS CIRÚRGICOS}

\subsubsection{Obtenção dos Animais}

Foram utilizadas, neste estudo, 42 cobaias (Cavia porcellus), machos e adultas (5 meses de idade e peso médio de 600g), fornecidas pelo Biotério Central da Faculdade de Odontologia de Bauru, USP. Todos os animais, divididos em 2 grupos (Tabela 3), foram alimentados com ração granulada da marca Purina para coelhos, capim, verduras e água à vontade durante todo o experimento.

Tabela 3: Grupos experimentais avaliados e respectivos períodos de sacrifício.

\begin{tabular}{ccc}
\hline Grupos & Material & Períodos de EutANÁsia \\
\hline Controle & $\begin{array}{c}\text { Espaçador de colágeno alogênico } \\
\text { inativado }\end{array}$ & 0 hora $^{*}, 1,3,6$ e 9 meses \\
Teste & Espaçador e dupla membrana & 1, 3, 6 e 9 meses \\
\hline
\end{tabular}

\footnotetext{
Apenas para análise radiográfica.
} 


\subsubsection{Procedimentos Cirúrgicos}

A Figura 2 apresenta um esboço do modelo experimental utilizado, onde o defeito ósseo é preenchido por duas membranas, o espaçador e o coágulo. Durante os procedimentos cirúrgicos, os animais submetidos à anestesia geral intraoperitoneal (Ketalar injetável, Parke-Davis - Achë Laboratórios Farmacêuticos S.A) relaxante muscular e sedativo de uso animal (Rompun, Bayer-S.A) foram tricotomizados na região frontoparietal da cabeça do animal, com auxílio de tesoura e lâmina de barbear e assepsia vigorosa com iodofor alcoólico (Figura 3 a-b). Com bisturi n¹0, foi realizada uma incisão em formato de meia-lua, no tegumento que reveste a calota craniana na região fronto-parietal (Figura 3 c). Com auxílio de um descolador de Molt e cinzel de Oshsenbein $\mathrm{n}^{\circ} 1$, o retalho foi levantado para posterior expondo amplamente a cortical óssea da região (Figura 3 d). A seguir, com a trefina cirúrgica de 10 mm de diâmetro (externo), irrigação abundante e contínua com solução fisiológica, realizou-se na região frontoparietal uma perfuração transpassando toda a espessura da díploe, expondo a dura-máter, no fundo do defeito, (Figura 3 e-f) onde foram colocadas duas membranas de cortical óssea bovina desmineralizada (Gen$\operatorname{derm}^{\circledR}$ ), uma em cima da dura-máter, fechando a abertura epidural, e outra na abertura ectodural, nos grupos experimentais (Figura 2, Figura 3 g-l). Entre elas foi colocado o espaçador de 3x3x3 mm de osso alógeno desmineralizado e inativado, a fim de evitar o colapso das membranas para dentro do defeito e manter a espessura da região em reparo. O grupo controle teve o defeito preenchido apenas com coágulo e o espaçador de osso alógeno desmineralizado e inativado. Os retalhos, a seguir, foram recolocados em sua posição e suturados (Figura $\mathbf{3} \mathbf{~ m}$ ) com linha de seda preta 
$\mathrm{n}^{\circ}$ 3-0 (Ethicon, Johnson \& Johnson). Todos os materiais de enxerto foram esterilizados previamente por radiação gama (25 Kgy).

Os animais foram mantidos em gaiolas separadas, por um período de 20 dias, e depois, reunidos em grupos de 5 animais e foram mantidos no Biotério Central da FOB-USP.

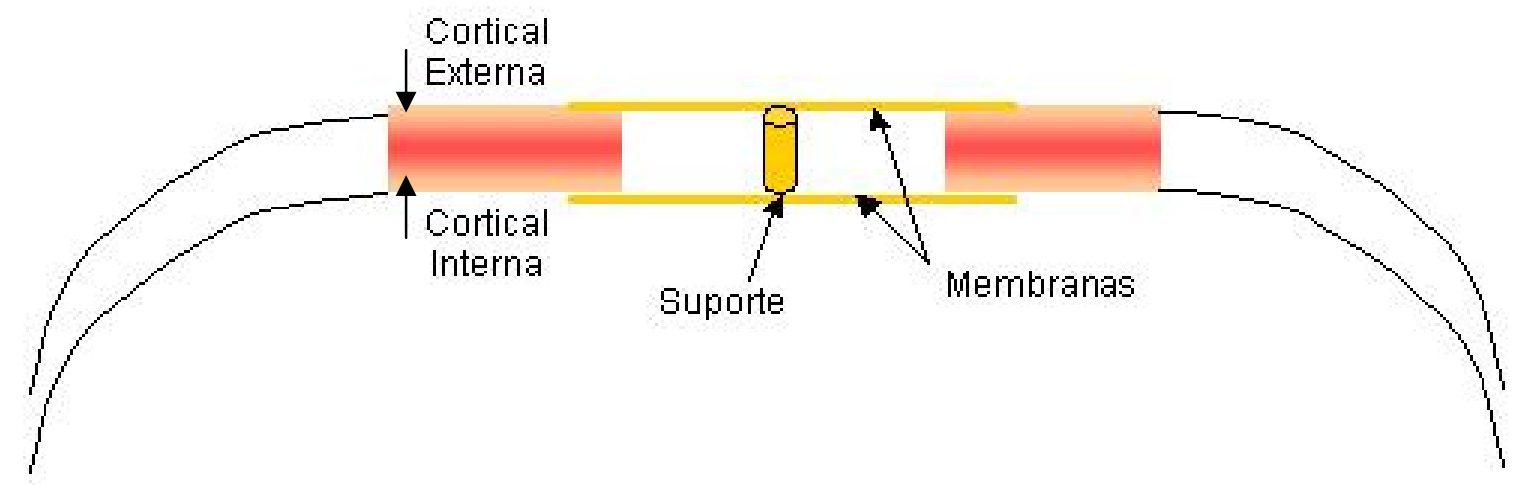

Figura 2: Esquema do procedimento para confecção do defeito ósseo na calota craniana de cobaia. 

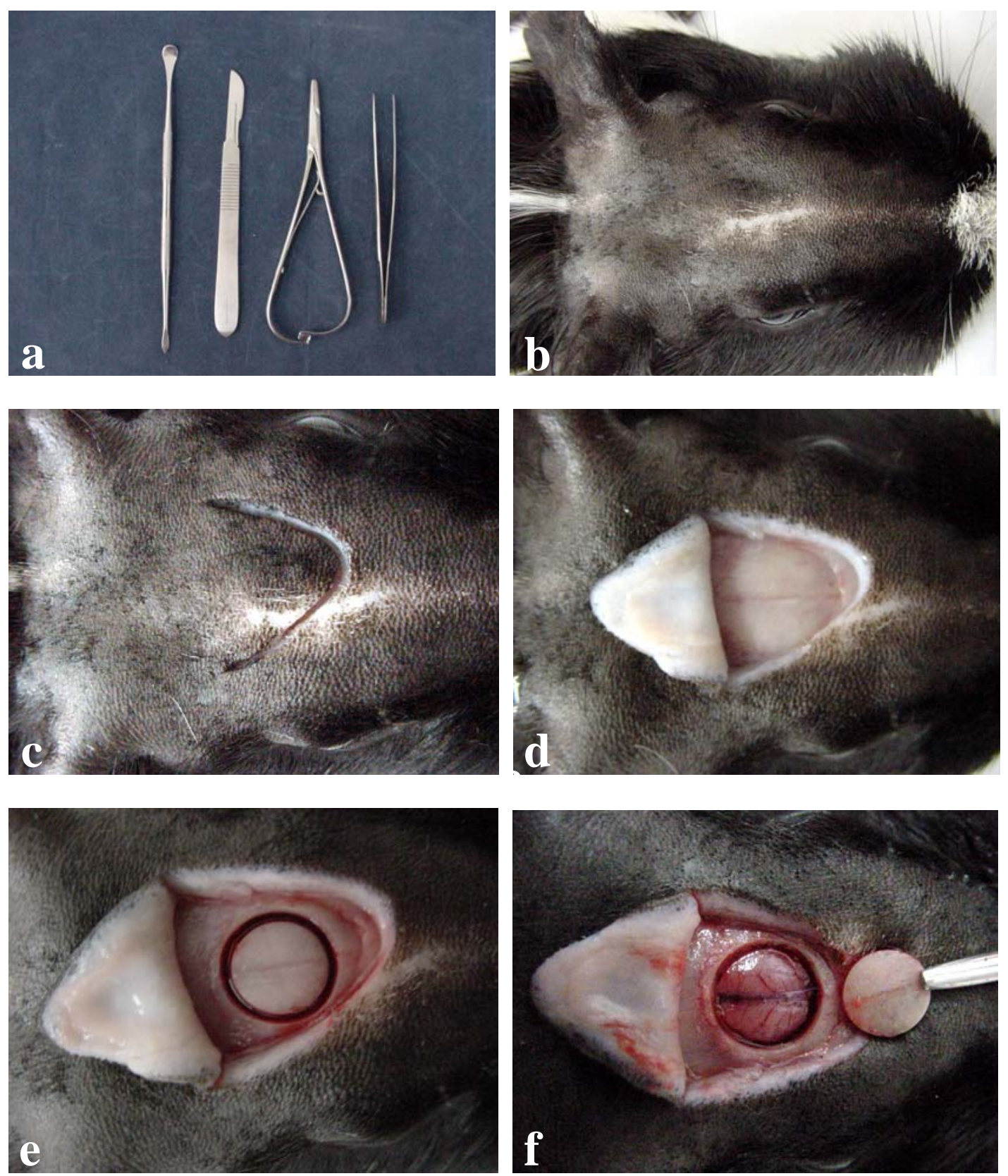

Figura 3 a-f: Procedimentos cirúrgicos: a) instrumentais utilizados; b) isolamento da área cirúrgica e assepsia da região onde foi realizada a tricotomia; c) incisão realizada em meialua na região fronto-parietal; d) levantamento do retalho + periósteo com exposição da superfície do crânio; e) defeito delimitado e realizado com a trefina; f) retirada do bloco ósseo de dentro do defeito através de um descolador Molt com a exposição da dura-máter. 

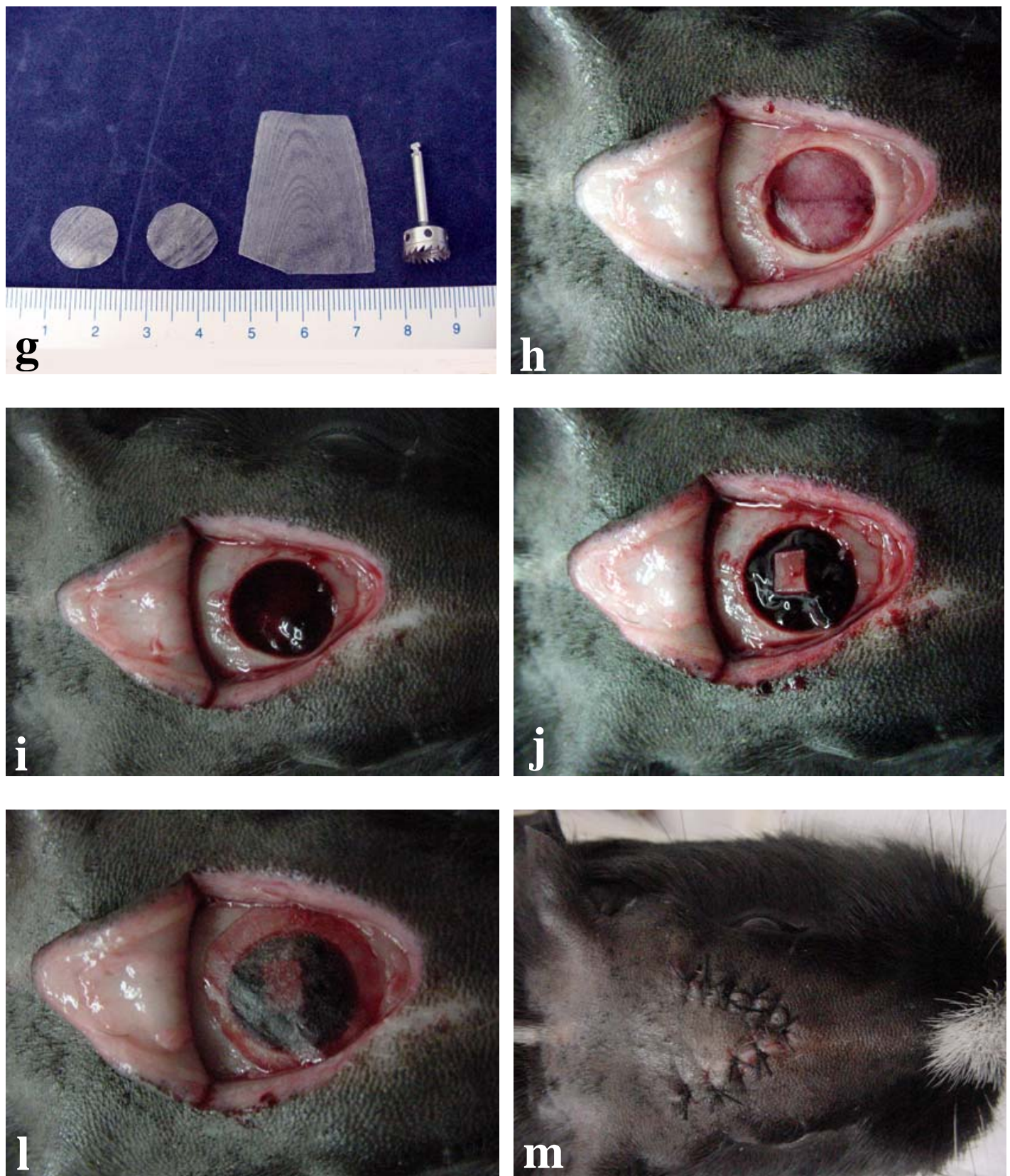

Figura 3 g-m: Procedimentos cirúrgicos: g); comparação do tamanho das membranas recortadas e da trefina utilizada; $\mathbf{h}$ ) colocação da membrana sobre a dura-máter e abaixo da cortical interna; i) membrana + coágulo; j) colocação do suporte de osso alógeno desmineralizado e desproteinizado de $3 \times 3 \mathrm{~mm}$ sobre a primeira membrana; l) implantação da segunda membrana sobre a cortical externa e o suporte; m) sutura do retalho. 


\subsection{OBTENÇÃO DAS BIÓPSIAS E PREPARO HISTOTÉCNICO}

Os animais foram sacrificados ao término dos períodos de 0 hora (grupo controle), 1, 3, 6 e 9 meses (grupo controle e teste) após as cirurgias com dose excessiva de anestésico. Em seguida foram coletadas as calotas cranianas com a pele sobreposta.

Todas as coletas foram realizadas entre das 8 às 11 horas da manhã, sendo, em seguida, submetidas ao processo de fixação em formol $10 \%$ tamponado $^{2}$ durante uma semana.

\subsection{PROCEDIMENTO HISTOTÉCNICO}

Após a coleta das peças e a obtenção das radiografias, procedeu-se a sua desmineralização, em solução de citrato de sódio e ácido fórmico, em partes iguais, segundo técnica de Morse modificada (Morse, 1945) ${ }^{*}$, e houve trocas desta solução realizada de 5 em 5 dias até a completa desmineralização.

Em seguida, as peças foram submetidas ao seguinte procedimento histotécnico:

a) Lavagem em água destilada por 24 horas;

b) banho em etanol $70 \%$ até o dia seguinte;

\footnotetext{
* Formol 10\% Tamponado

Formoldeído 40\% $10 \mathrm{ml}$

Tampão Fosfato de Sódio*, pH 7,0 $90 \mathrm{ml}$

* Tampão fosfato de sódio:

Monofosfato de sódio hidratado $\left(\mathrm{NaH}_{2} \mathrm{PO}_{4} \cdot \mathrm{H}_{2} \mathrm{O}\right) \quad 4,02 \mathrm{~g}$

Difosfato de sódio hidratado $\left(\mathrm{NaHPO}_{4} \cdot 12 \mathrm{H}_{2} \mathrm{O}\right) \quad 16,37 \mathrm{~g}$

Água destilada q.s.p. $\quad 1000 \mathrm{ml}^{2}$
} 
c) início do processo de desidratação em etanol a 80\% por 1 hora;

d) banho de uma hora em etanol a $90 \%$;

e) banho de uma hora em etanol a $95 \%$;

f) dois banhos de uma hora em etanol a 100\%;

g) banho de etanol a $100 \%$ durante 24 horas;

h) início do processo de diafanização xilol histológico (Merck) por 30 minutos;

i) banho de uma hora em xilol;

j) banho em Histosec (parafina+resina sintética, Merck) liquefeita em estufa a $60^{\circ} \mathrm{C}$ por uma hora;

k) banho em Histotec liquefeita em estufa a $60^{\circ} \mathrm{C}$ por vinte horas;

l) inclusão em Histotec liquefeita;

m) cortes semi-seriados de $5 \mu \mathrm{m}$ de espessura, no sentido laterolateral (micrótomo Jung-Leica RM2045) e corados pela técnica da Hematoxilina- Eosina (HE, Luna, 1968).

\subsection{ANÁLISE MICROSCÓPICA}

As lâminas obtidas de cortes histológicos foram examinadas num microscópio binocular Axioskop 2 (Carl Zeiss). Na análise microscópica foram observadas a ocorrência dos seguintes eventos:

a) Presença do coágulo sangüíneo e infiltrado inflamatório;

b) intensidade da angiogênese;

c) presença de tecido de granulação; 
d) reabsorção da membrana de cortical óssea bovina;

e) reorganização do periósteo;

f) formação de tecido ósseo.

As fotografias foram obtidas, a partir dos cortes histológicos, num sistema fotográfico, composto de um microscópio Axioskop (Zeiss), câmera fotográfica e software MC200 chip. O aumento final da fotografia foi obtido a partir do aumento da objetiva $\mathrm{x}$ aumento da projetora $(10 \mathrm{x}) \mathrm{x}$ aumento da câmera fotográfica para 35mm (0,32x) x aumento da revelação (4,26x).

\subsection{ANÁLISE MORFOMÉTRICA DAS IMAGENS RADIOGRÁFICAS}

Após a fixação das peças, as calotas cranianas foram radiografadas utilizando placas ópticas expostas segundo os parâmetros: 70 kVp, 10 mAs, distância foco-filme de $40 \mathrm{~cm}$ e tempo de exposição de 0,26s. As radiografias digitalizadas foram analisadas pelo sistema software Kontron KS300 (Kontron Eletronic GMBM), calculando-se a densitometria óssea de cada defeito em reparo e correlacionando-a com as respectivas características microscópicas.

A área radiolúcida do defeito (Arluc), em cada período experimental, foi determinada a partir de imagens radiográficas transferidas para o sistema de análise de imagem digitalizada. Para tanto, foi montado, no sistema, um programa designado “macro cobaia” para realização automática das medidas. (Figura 4 a). O modo de obtenção das medidas está detalhado a seguir. A área inicial da lesão (Ai) no grupo 0h e a área da lesão em que não houve formação de tecido ósseo (A) nos demais 
tempos foram determinados (Figura 4 a-b). A área de lesão preenchida por tecido ósseo neoformado (Arop) para cada animal foi calculada pela relação Arop $=\mathrm{Ai}-$ Arluc. Como o sistema de análise de imagem fornece a área em pixel ${ }^{2}$, durante os procedimentos cirúrgicos, foram obtidos com um paquímetro as medidas (em mm) dos diâmetros sagital e medial do defeito criada por cada trefina no grupo de 0 hora. De posse do diâmetro médio, foi calculada a área inicial do defeito em $\mathrm{mm}^{2}$ (Ai), usando a área da fórmula do circulo, $\mathrm{Ai}=\pi \mathrm{r}^{2}$, onde $\mathrm{r}=$ raio médio. Conhecendo-se a área inicial do defeito em $\mathrm{mm}^{2}$ e a área da lesão em pixel $^{2}$ obtida através do KS300, foi calculado, por uma regra de três, o valor médio em $\mathrm{mm}^{2}$ para cada pixel $^{2}$.Os dados obtidos para o grupo controle e experimentais foram confrontados entre si, através de uma análise descritiva e análise de regressão linear com correção de Bonferroni. 


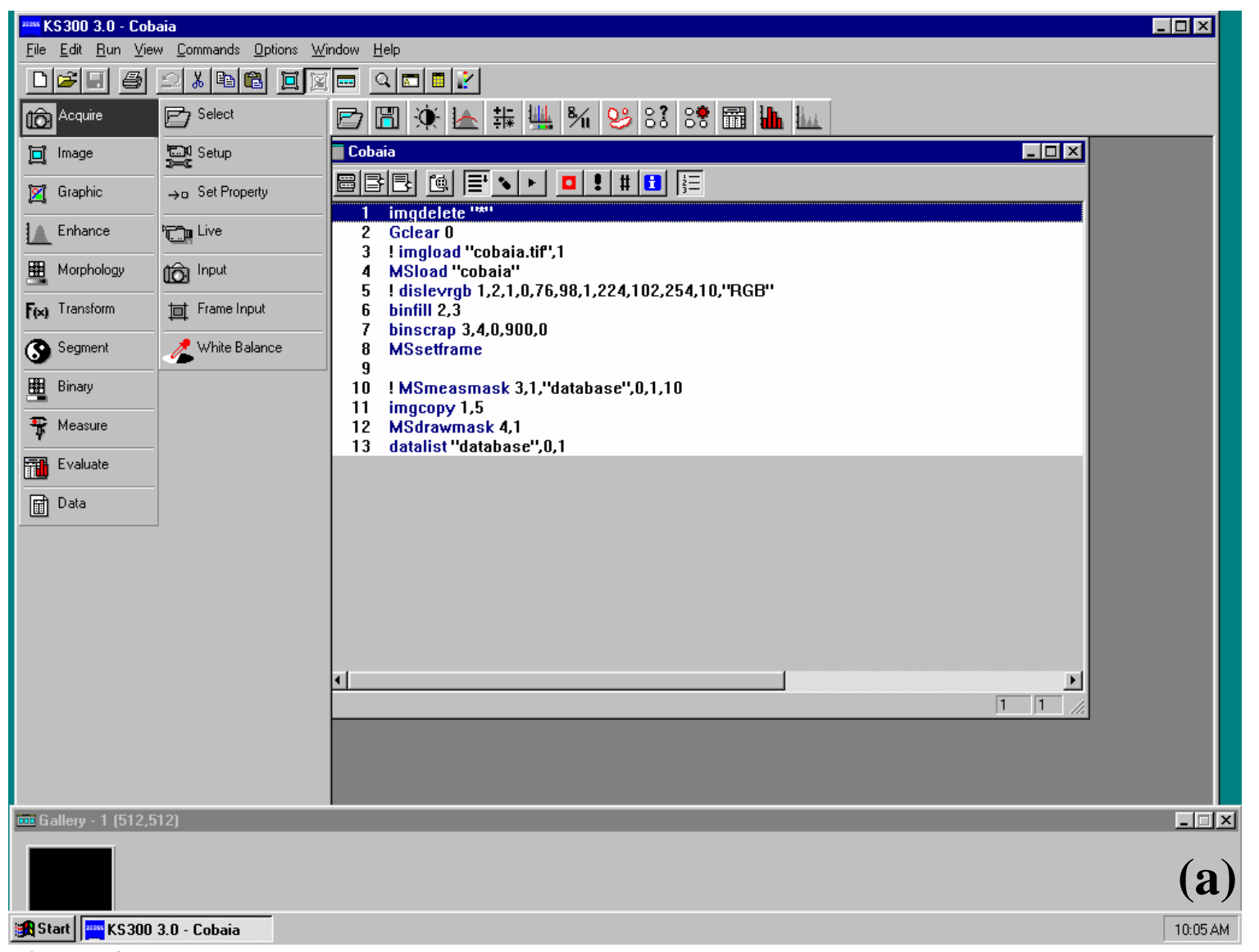

Figura 4 a: Tela principal do Programa KS300 Carl Zeiss apresentando a programação "macro" devidamente montada da área do defeito. 

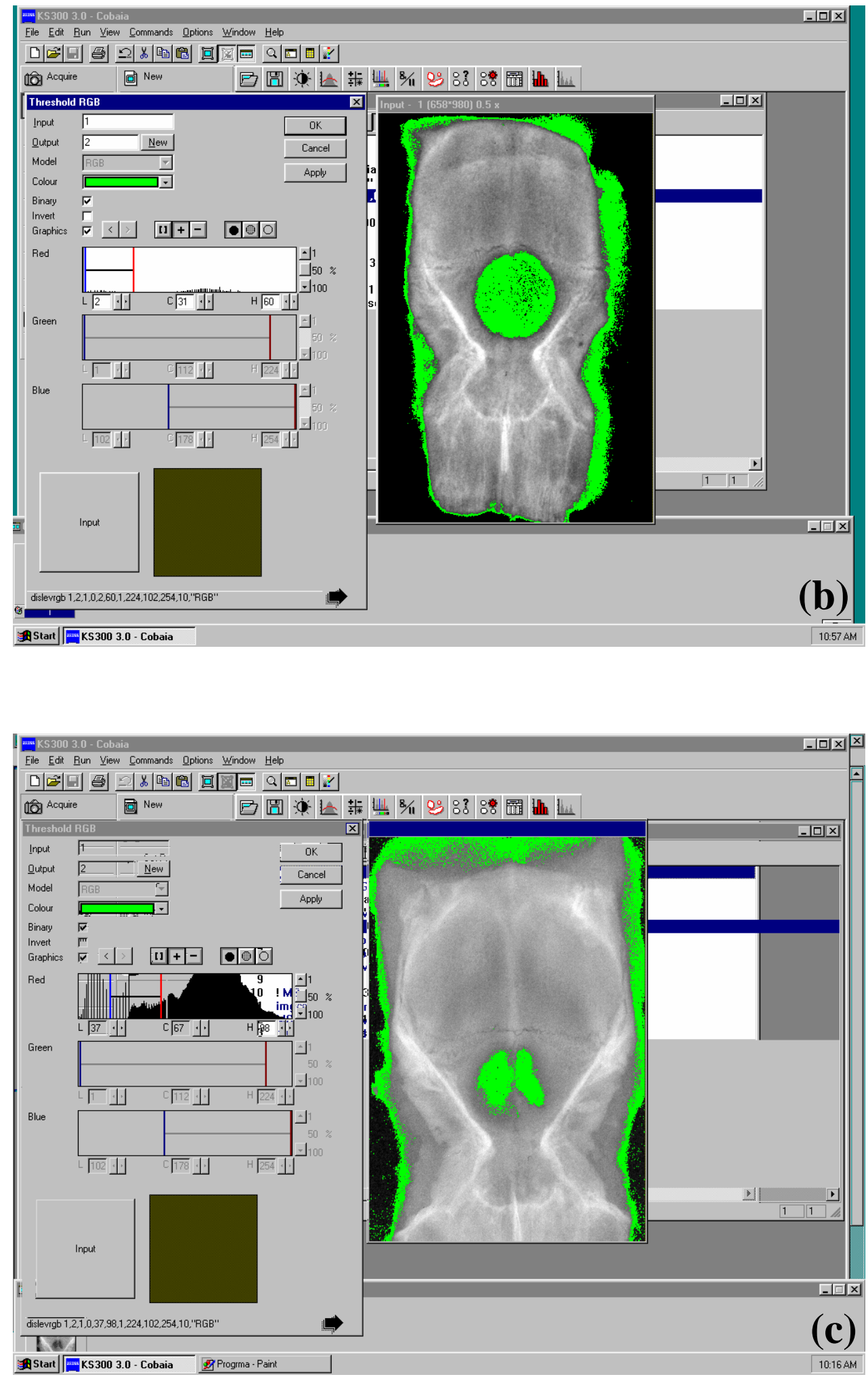

Figura 4. b,c: b) Programação "macro cobaia” no KS300 Carl Zeiss no modo interativo para o isolamento da área radiolúcida. c) animal do período de 6 meses. 

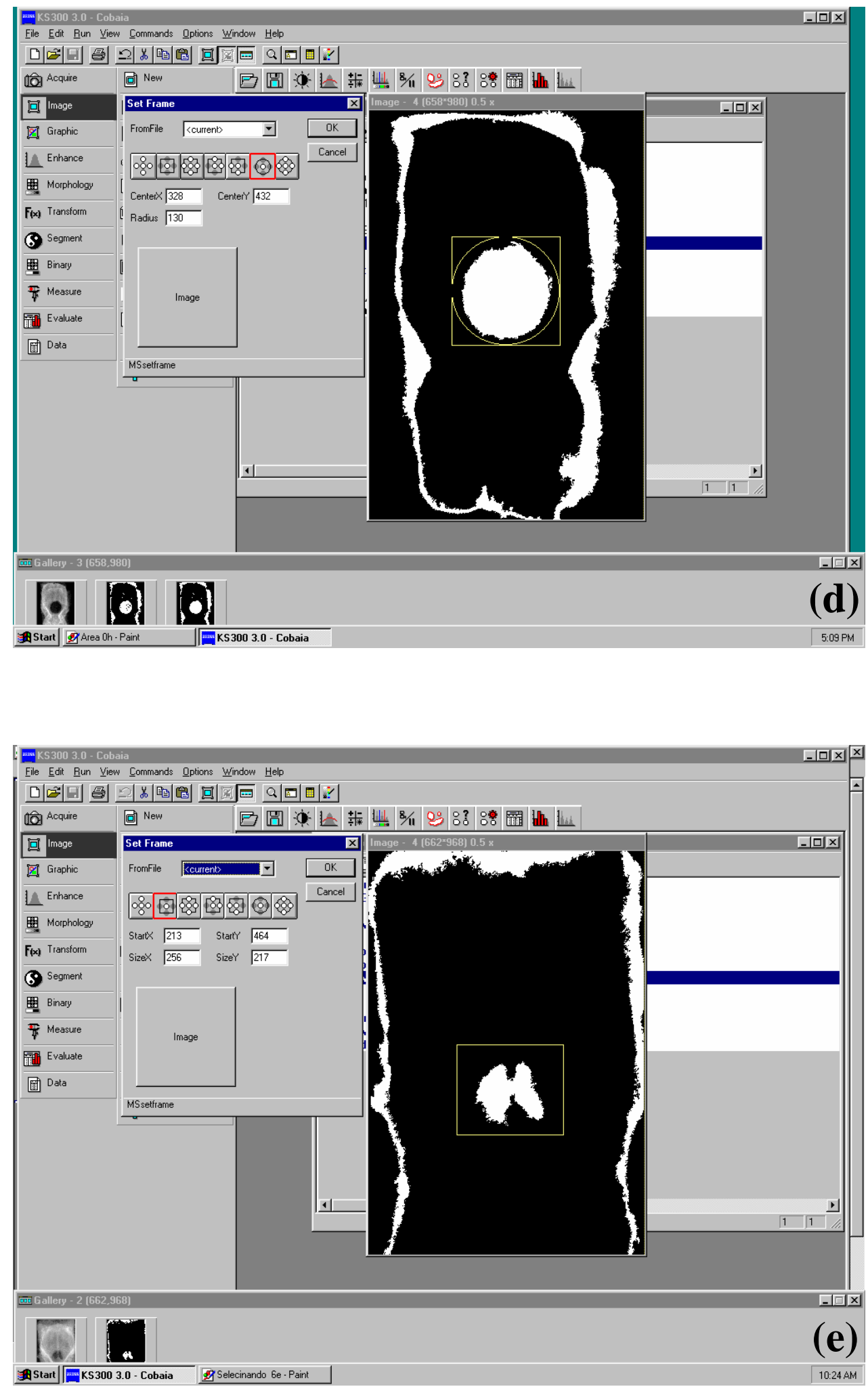

Figura 4 d,e: $\quad$ d) Programação “macro cobaia” no KS300 Carl Zeiss durante a aplicação da máscara para isolamento da área a ser quantificada. e) animal do período de 6 meses. 

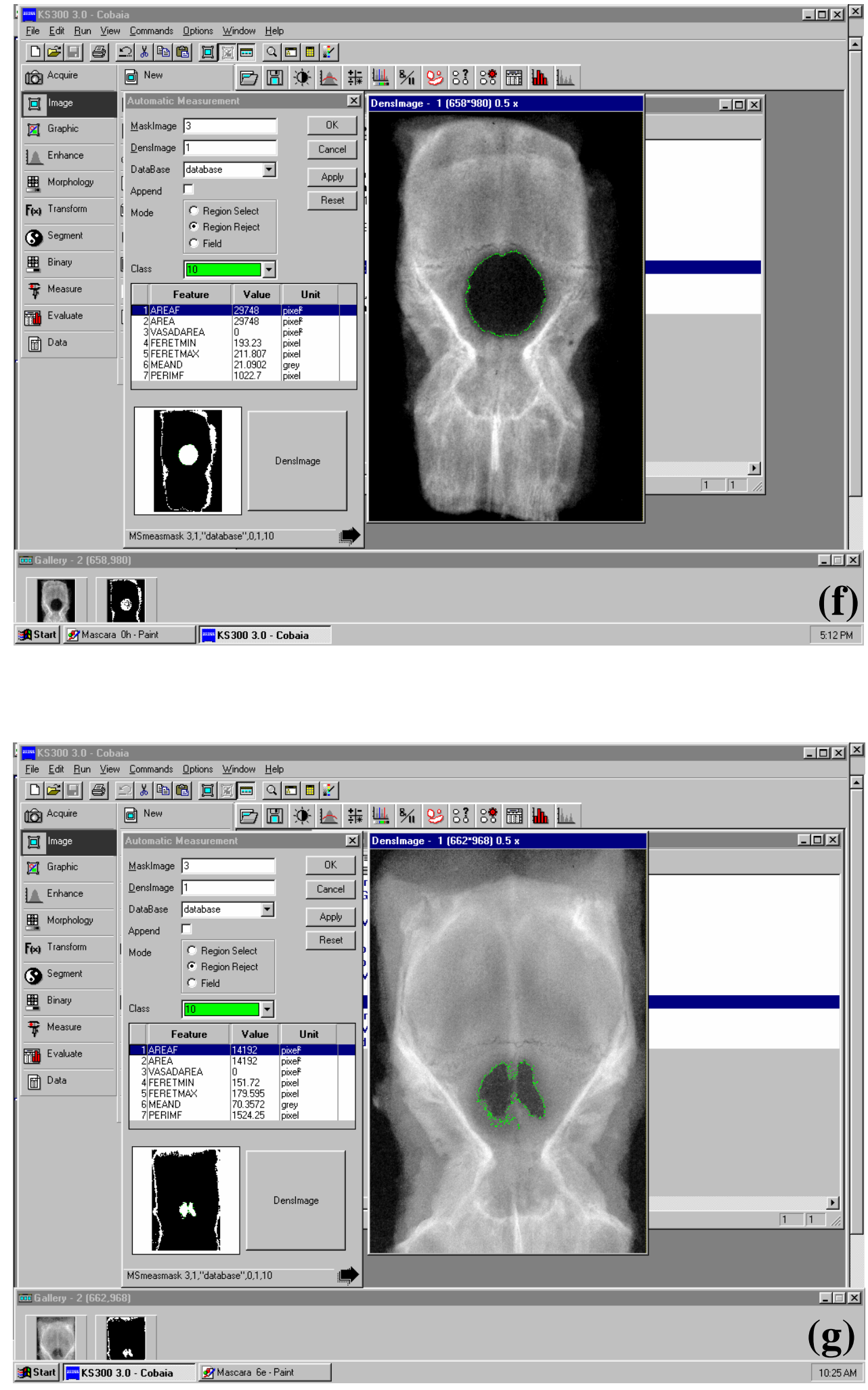

Figura 4.f,g: f) Determinação da área radiolúcida em pixels ${ }^{2}$ na Programação "macro cobaia” no KS300 Carl Zeiss. g) animal do período de 6 meses. 


\subsection{ANÁLISE ESTATÍSTICA}

Optou-se por duas análises, uma descritiva e uma análise inferencial, utilizando-se a regressão linear múltipla com correção de Bonferroni, usando-se duas variáveis grupo e tempo, utilizando-se os resultados obtidos pela morfometria das radiografias dos grupos controle e experimental nos períodos de 1, 3, 6 e 9 meses. 
5. Resultados 


\section{RESULTADOS}

\subsection{ANÁLISE MICROESTRUTURAL DA MEMBRANA}

As análises das fotomicrografias eletrônicas de varredura (Figuras. 5a-d) mostraram que: a) os poros da membrana apresentaram-se homogeneamente distribuídos; b) os poros pequenos exibiram diâmetro médio de 9,98 $\mu \mathrm{m}$, enquanto que os poros grandes, referentes aos canais de Haver e Volkmann, apresentaram diâmetro médio de 61,98 $\mu \mathrm{m}$; c) os poros referentes aos canais de Havers exibiram inúmeros canais conectivos, os canais de Volkmann; d) o número de poros grandes e pequenos foi de $12,5 \mathrm{~mm}^{2}$ e $3,1 \mathrm{~mm}^{2}$ respectivamente.
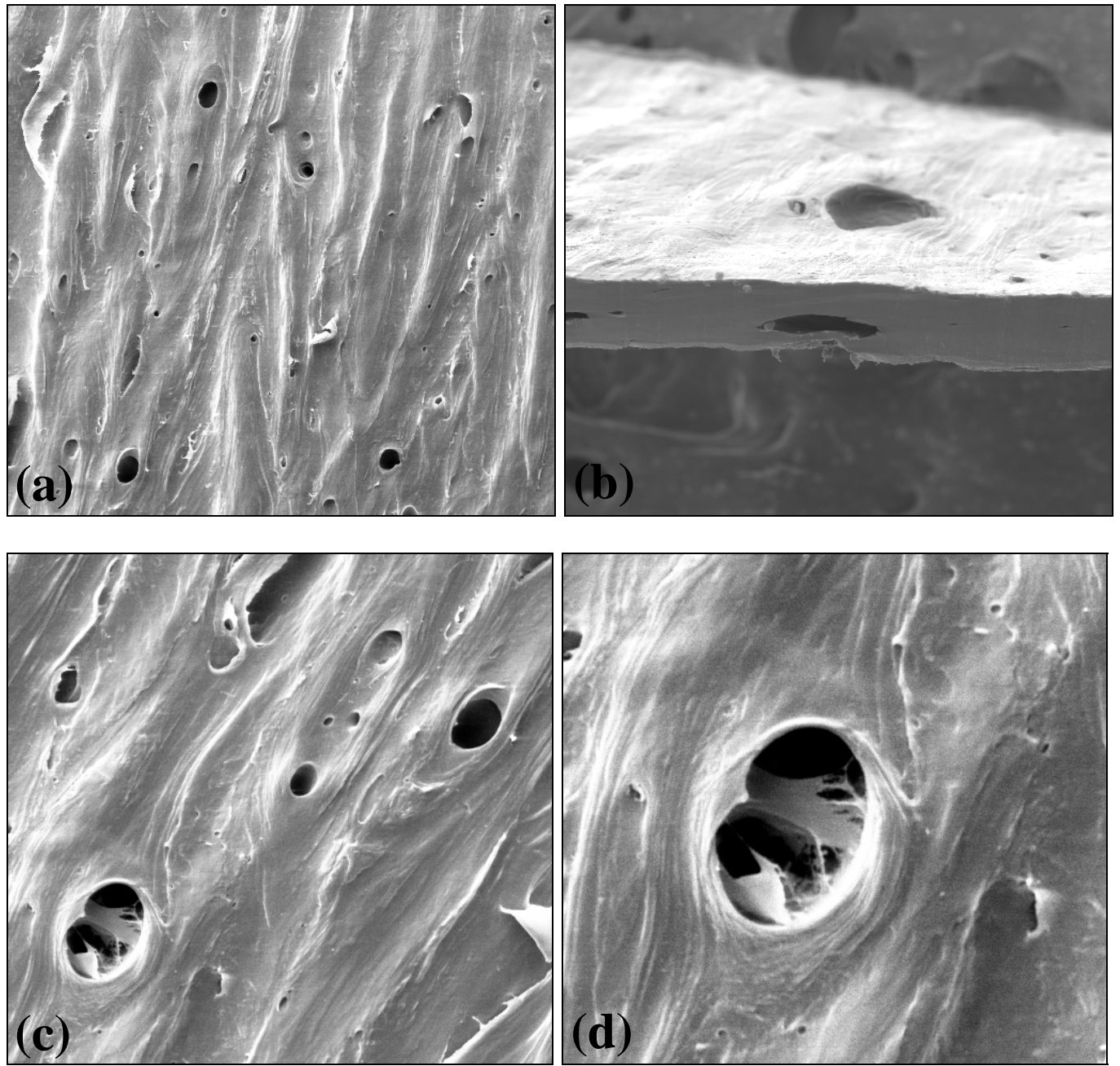

Figura 5: Microscopia eletrônica de varredura - detalhes dos poros da membrana de cortical óssea bovina liofilizada. 


\subsection{ANÁLISE MORFOMÉTRICA DAS IMAGENS RADIOGRÁFICAS}

As imagens radiográficas obtidas para os animais dos grupos 0 hora, controle e experimental estão apresentadas nas figuras 6-10 e a área total do defeito em $\mathrm{mm}^{2}$ no anexo 1.
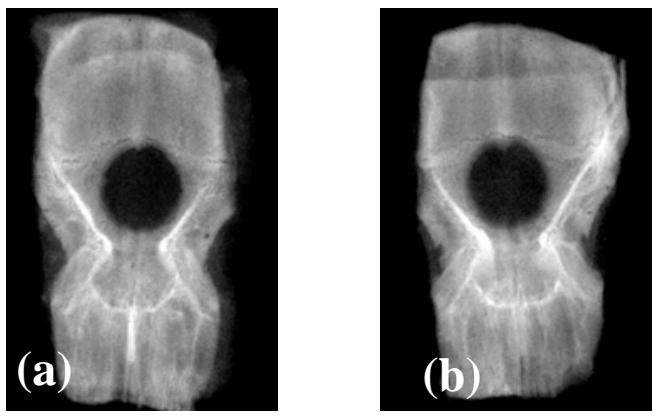

Figura 6. Imagens radiográficas dos crânios dos animais no período de 0 hora pós-cirúrgico (imediatamente após a cirurgia).
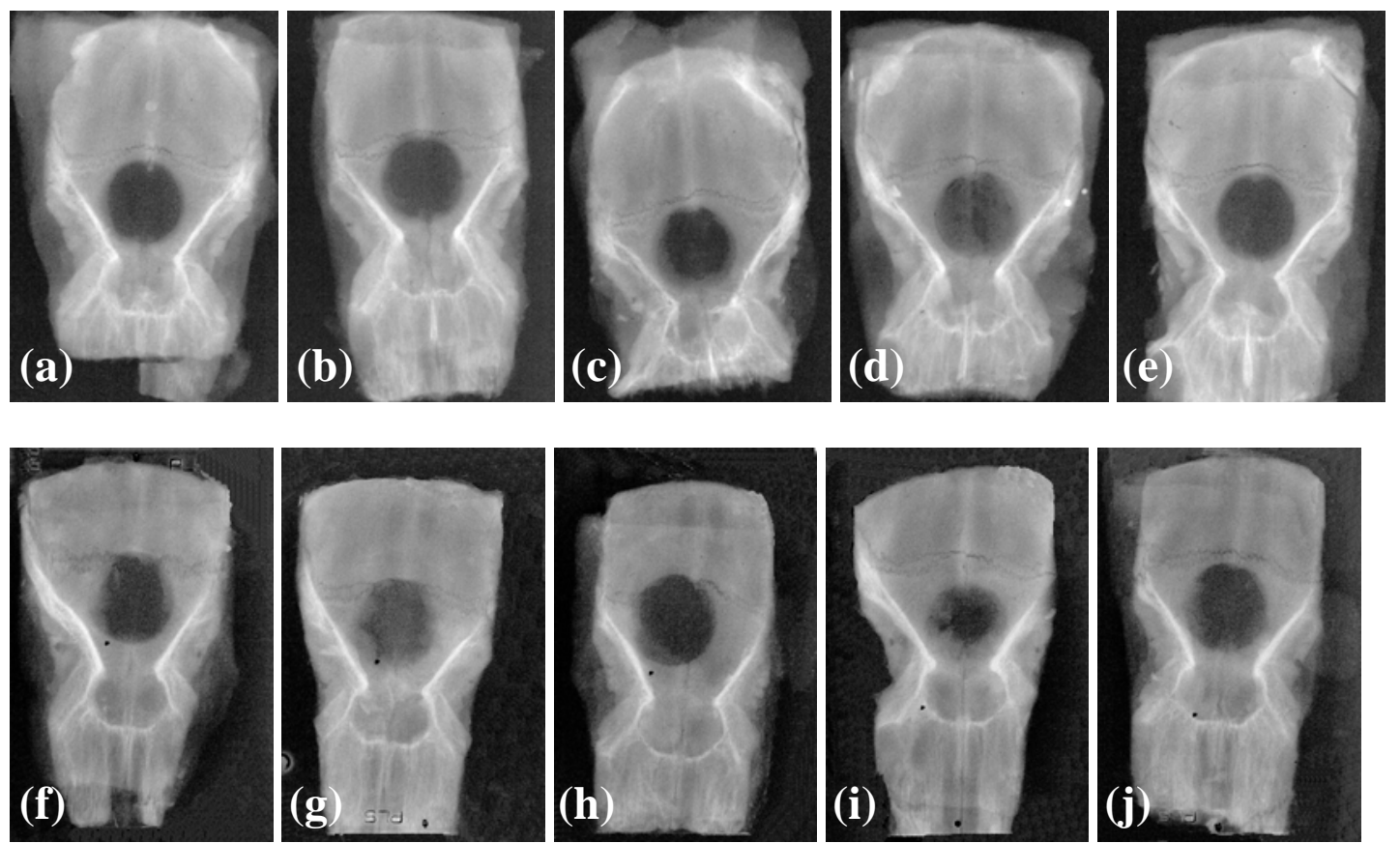

Figura 7. Imagens radiográficas da calvária dos animais do período de 1 mês: grupo controle (a-e) e grupo experimental (f-j). 

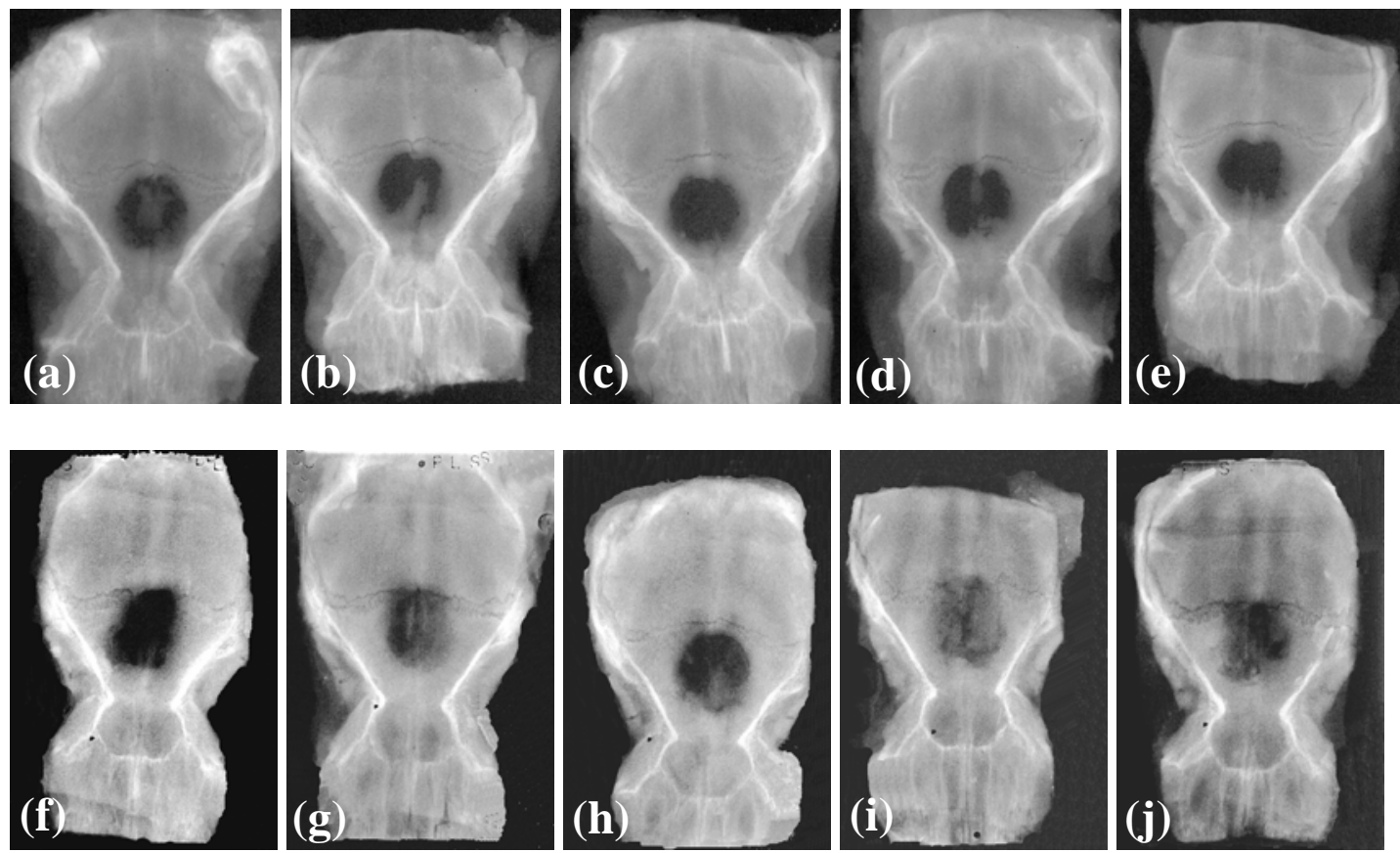

Figura 8. Imagens radiográficas da calvária dos animais do período de 3 meses: grupo controle (a-e) e grupo experimental (f-j).
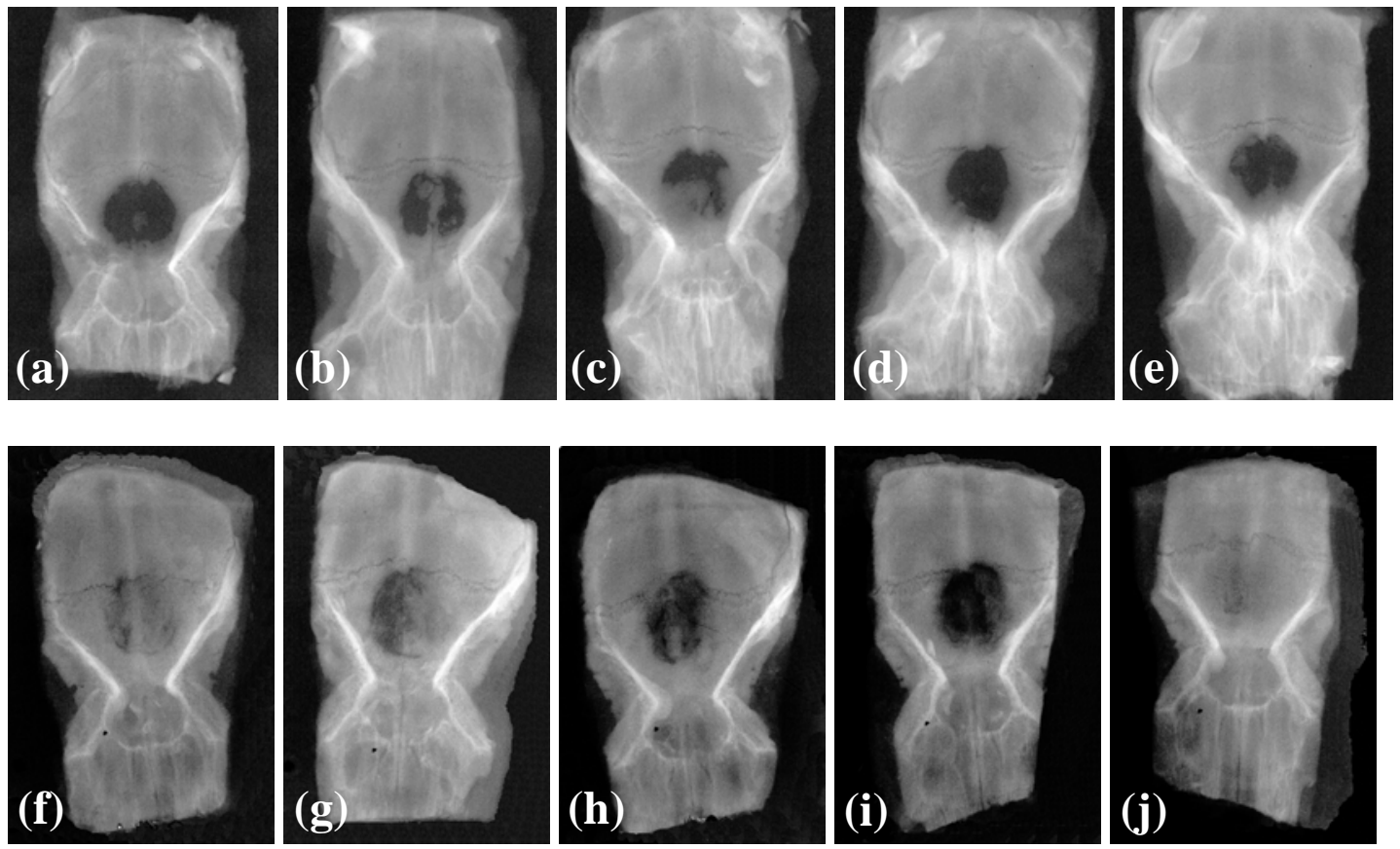

Figura 9. Imagens radiográficas da calvária dos animais do período de 6 meses: grupo controle (a-e) e grupo experimental (f-j). 


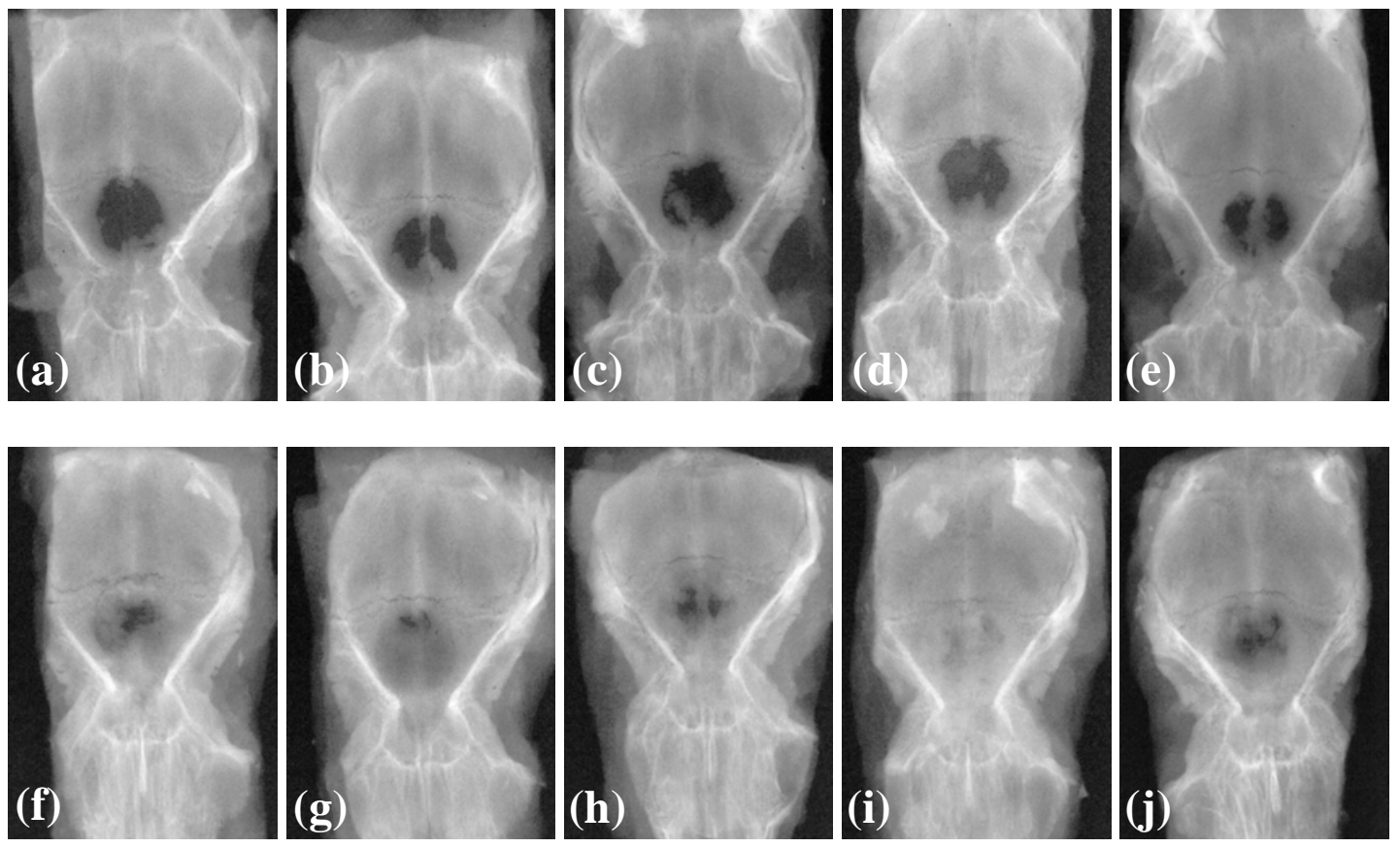

Figura 10. Imagens radiográficas da calvária dos animais do período de 9 meses: grupo controle (a-e) e grupo experimental (f-j).

No grupo controle e experimental de 1 mês, observou-se que houve aumento de radiopacidade sugestiva de formação óssea pelas bordas do defeito representado por uma área radiodensa localizada principalmente nas regiões posterior e lateral do defeito. O processo de reparo foi similar em todos os espécimes, havendo num caso, área radiodensa maior que nos outros (Figura 7i).

No período de 3 meses, a radiopacidade das bordas aumentou tanto no grupo controle como no experimental. Em alguns casos havia uma área radiodensa na região central do defeito (controle - Figura 8a,b). Em três espécimes do grupo experimental (Figura 8g, i, j), a área radiodensa compatível com uma formação óssea foi maior dos que nos outros espécimes.

A radiopacidade compatível com uma formação óssea pelas bordas posterior e lateral continuou no grupo controle de 6 meses, havendo como no período de 1 mês uma área radiodensa compatível com tecido ósseo (Figura 9b,c). Um dos espécimes 
apresentou uma formação óssea maior em relação aos outros elementos do grupo controle (Figura 9c). No grupo experimental, um defeito apresentou-se totalmente preenchido por uma área radiodensa compatível com tecido ósseo (Figura 9j); outro, quase que totalmente preenchido (Figura 9f), e os espécimes restantes parcialmente preenchidos por uma área radiodensa em quantidade semelhante.

A formação óssea, no período de 9 meses, mostrou-se totalmente diferente nos grupos controle e experimental. No grupo controle, a área radiolúcida pareceu aumentar, comparada ao grupo controle de 6 meses. A área radiodensa compatível com formação óssea ocorreu principalmente nas bordas posterior e lateral, havendo dois espécimes com uma área radiodensa compatível com tecido ósseo na região central. Já no grupo experimental, houve uma semelhança nos resultados obtidos, o fechamento quase total de todos os defeitos (área radiodensa preenchendo quase que totalmente o defeito).

\subsection{ANÁLISE ESTATÍSTICA}

\subsubsection{RESUMO}

\subsubsection{DESCRIÇÃO DAS VARIÁVEIS}

As variáveis utilizadas na análise foram Grupo e Tempo. 


\subsubsection{ANÁLISE DESCRITIVA}

A análise descritiva sugere que o grupo controle se comporta de maneira diferente do grupo experimental. Como podemos perceber pela tabela e pelo gráfico a seguir, notamos que para o grupo experimental a média de área radiolúcida (arluc) decresce com o tempo; ao contrário disso, para o grupo controle a média de arluc parece apresentar uma relação quadrática com o tempo, basta observar a queda da média de arluc até o sexto mês, sendo que depois constatamos o aumento da média do grupo do sexto mês para o grupo de 9 meses (Tabela 4 e figura 11). 
Tabela 4. Medidas descritivas da variável arluc $\left(\mathrm{mm}^{2}\right)$

\begin{tabular}{cccccc}
\hline GRUPO & $\begin{array}{c}\text { TEMPO } \\
\text { (MESES) }\end{array}$ & N & MÉdiA & MEDIANA & $\begin{array}{c}\text { DESVIO } \\
\text { PADRÃo }\end{array}$ \\
\hline Padrão & $0 \mathrm{H}$ & 2 & 66,3 & 66,3 & 0,2 \\
\hline \multirow{3}{*}{ Controle } & 1 & 5 & 52,2 & 51,7 & 7,1 \\
& 3 & 5 & 40,7 & 42,2 & 11,9 \\
& 6 & 5 & 29,6 & 32,7 & 14,0 \\
& 9 & 5 & 36,2 & 37,1 & 7,3 \\
& Total & 20 & 39,6 & 42,0 & 12,8 \\
\hline \multirow{3}{*}{ Experimental } & 1 & 5 & 45,3 & 47,8 & 16,4 \\
& 3 & 5 & 26,6 & 22,4 & 11,3 \\
& 6 & 5 & 12,0 & 12,8 & 9,5 \\
& 9 & 5 & 2,5 & 2,2 & 1,7 \\
& Total & 20 & 21,6 & 19,5 & 19,4 \\
\hline \multirow{2}{*}{ Total } & 0 & 2 & 66,3 & 66,3 & 0,2 \\
& 1 & 10 & 48,7 & 49,7 & 12,4 \\
& 3 & 10 & 33,7 & 37,5 & 13,2 \\
& 6 & 10 & 20,8 & 21,1 & 14,6 \\
& 9 & 10 & 19,3 & 15,5 & 18,4 \\
& Total & 42 & 32,3 & 35,3 & 19,8 \\
\hline
\end{tabular}

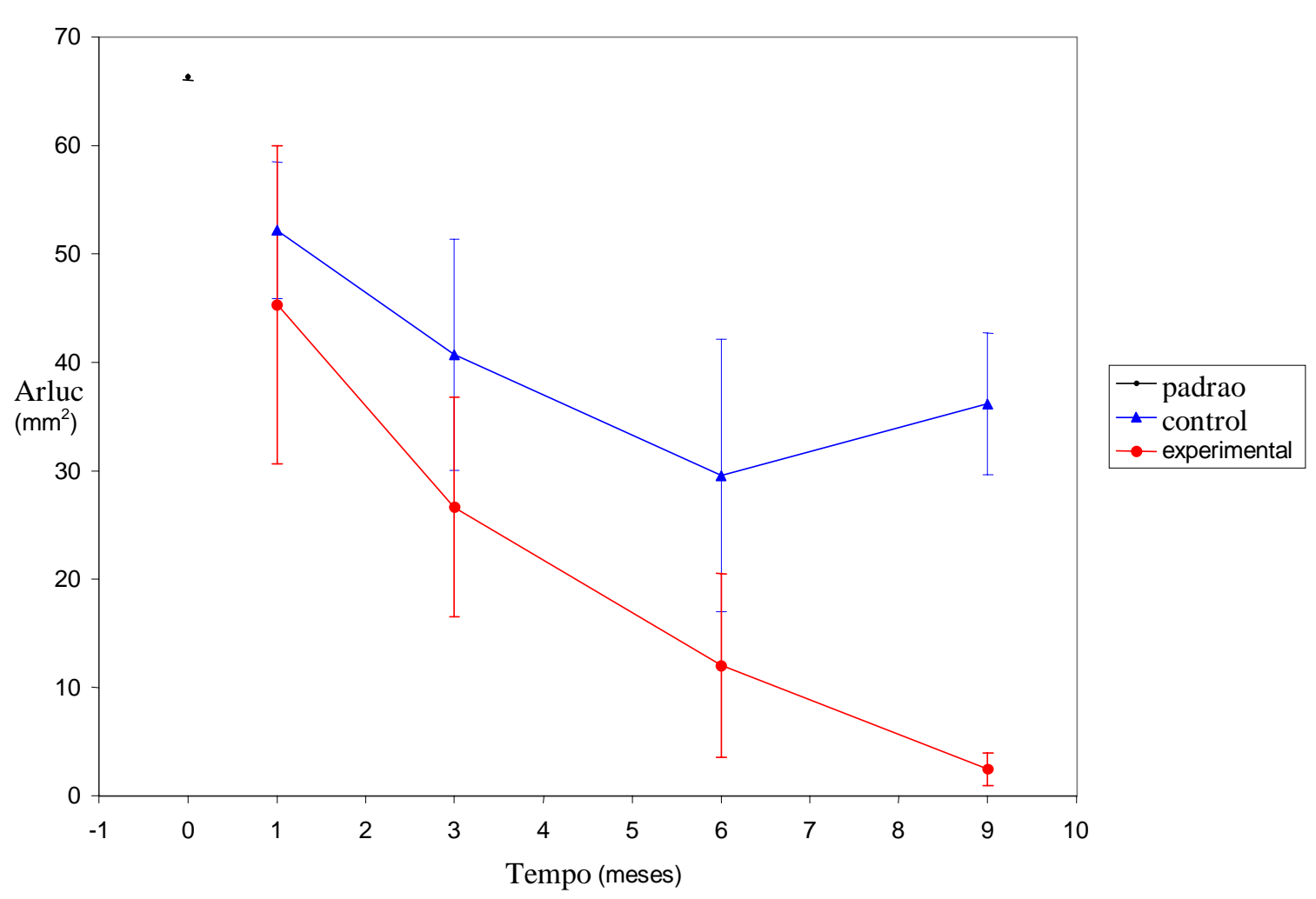

Figura 11. Perfis médios com intervalo de confiança de 95\% das médias 
Comparando os perfis médios dos grupos controle e experimental, notamos uma diferença evidente apenas na último mês. Outro fato que chama a atenção é a menor variabilidade apresentada pelos indivíduos do grupo experimental de 9 meses.

\subsubsection{ANÁLISE INFERENCIAL}

Para verificar a diferença entre os grupos, utilizamos uma regressão linear múltipla com os seguintes fatores: grupo, tempo, tempo ${ }^{2}$, grupo*tempo, grupo*tempo ${ }^{2}$. Em virtude da multicolinearidade dos dados, tivemos que transformar a variável tempo, subtraindo a média dessa variável para cada indivíduo. Vamos chamar essa nova variável de TempoPad. Portanto, as variáveis Grupo e TempoPad ficaram da seguinte forma:

Tabela 5. Relação das variáveis que foram analisadas.

\begin{tabular}{cc}
\hline FATOR & VALORES \\
\hline Grupo & $0-$ Experimental \\
TempoPad & 1 - Controle \\
& $($ Tempo $-4,75)$ \\
\hline
\end{tabular}

Observe que 4,75 meses é média dos valores 1, 3, 6 e 9.

Com isso, obtivemos os seguintes resultados: 
Tabela 6. Resultados da Regressão Linear

\begin{tabular}{cccc}
\hline FATOR & COEFICIENTE & $\begin{array}{c}\text { ERRO PADRÃO } \\
\text { COEFICIENTE }\end{array}$ & P \\
\hline Intercepto & 16,93 & 3,95 & 0,00 \\
Grupo & 15,65 & 5,58 & 0,01 \\
TempoPad & $-5,48$ & 0,80 & 0,00 \\
Grupo*TempoPad & 2,98 & 1,13 & 0,01 \\
TempoPad $^{2}$ & 0,51 & 0,34 & 0,15 \\
Grupo*TempoPad $^{2}$ & 0,26 & 0,49 & 0,60 \\
\hline
\end{tabular}

Esse foi o modelo que mais se adequou aos dados. Observamos duas parábolas, portanto, nos dois grupos a variável arluc e o tempo apresentam uma relação quadrática. As curvas estimadas podem ser vistas no gráfico abaixo:

Curvas estimadas e Dados - Arluc vs Tempo

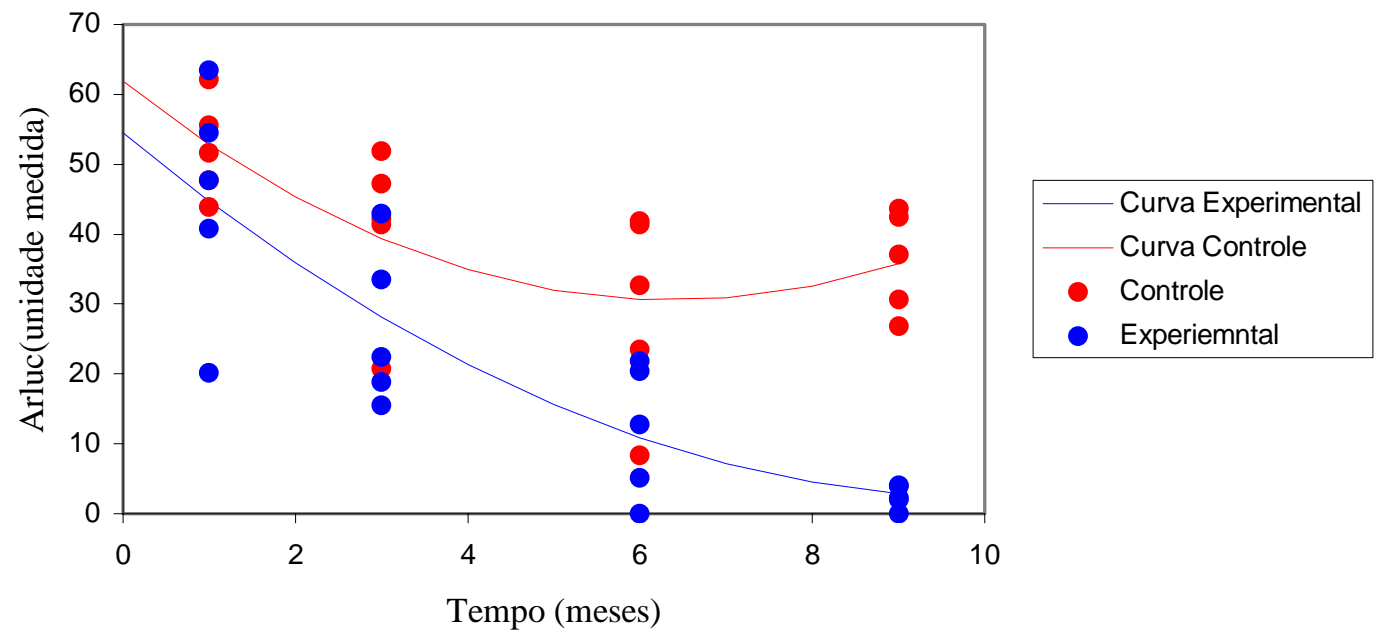

Figura 12. Gráfico mostrando as curvas estimadas e dados - Arluc versus tempo.

Através do modelo também comparamos as diferenças entre as médias e os resultados foram: 
Tabela 7. Valores da diferença média estimada e limites inferior e superior para os períodos estudados.

\begin{tabular}{ccccc}
\hline \multirow{2}{*}{ TEMPO (MESES) } & DIFERENÇA MÉdIA ESTIMADA & INTERVALO DE CONFIANÇA DE 95\% \\
\cline { 2 - 4 } & (CONTROLE - EXPERIMENTAL) & LIMITE INFERIOR LIMITE SUPERIOR \\
\hline 1 & 8,13 & $-8,47$ & 24,73 \\
3 & 11,23 & $-0,87$ & 23,34 \\
$6 *$ & 19,78 & 5,47 & 34,09 \\
$9 *$ & 32,98 & 15,71 & 50,25 \\
\hline
\end{tabular}

*Diferenças estatisticamente significantes utilizando $\alpha=0,05$ e correção de Bonferroni

Ocorreram diferenças estatisticamente significantes entre os grupos controle e experimental de 6 meses, essa diferença se acentuou entre os grupos de 9 meses como observamos pela tabela anterior.

As diferenças entre os grupos puderam ser observadas de forma mais clara a partir do sexto mês. A diferença média entre os grupos controle aumentou quando comparamos o sexto e o nono mês. Isso se deve não só à diminuição dos valores de arluc do grupo experimental, mas também, ao aumento médio que ocorreu no grupo controle.

\subsection{ANÁLISE MICROSCÓPICA}

Durante o acompanhamento pós-cirúrgico dos animais, não se notou qualquer sinal externo sugestivo de infecção na região operada. Alguns apresentaram pequeno edema, que desapareceu poucos dias depois, sem ocorrência de supuração e abertura da incisão.

O grupo experimental de 1 mês apresentou em 2 animais a membrana parcialmente íntegra tanto na superfície periostal quanto na dural (Figuras 13 e 14). A membrana da região da epidural apresentou-se envolta por tecido conjuntivo 
ricamente celularizado e vascularizado (Figura 15a, b), que também ocupava os antigos canais nutritivos (Figuras 16a, b) e as lacunas com células mononucleadas e restos sanguíneos (Figuras 16a, b). A membrana, na região da dura-máter, mostrou-se envolvida por tecido ósseo primário neoformado de arranjo trabeculado, intimamente associada a sua superfície (Figura 15b), aumentando substancialmente a espessura óssea na região (Figura 15b). Ausência de infiltrado inflamatório.

Na superfície periostal, observamos a presença de um tecido conjuntivo denso e celularizado em íntimo contato com o tecido ósseo neoformado (Figura 17a).

No interior do defeito, ocorreu intensa formação óssea, a partir da sua borda (Figura 17b) em direção à região central onde num caso ainda estava presente, o espaçador de matriz alogênica, envolto por tecido conjuntivo e com sinais de reabsorção na sua superfície externa (Figura 13) e no outro caso, todo o espaço do defeito mostrou-se preenchido por tecido ósseo entrelaçado, não sendo observados sinais do espaçador (Figura 14). Neste caso, graças à rápida formação óssea, foram observados restos do coágulo sanguíneo aprisionados no interior da matriz óssea recém sintetizada (Figura 18a b).

Entretanto em 3 animais as membranas mostraram-se total ou parcialmente reabsorvidas por células mononucleadas, com pequena neoformação óssea na superfície da borda óssea voltada a dura-máter (Figura 19), enquanto o defeito exibiu-se preenchido por espesso tecido conjuntivo rico em células e vasos sanguíneos (Figura 19) e em dois casos tendo na região central o espaçador de matriz alogênica parcialmente reabsorvida. 
O grupo controle de 1 mês apresentou pequena formação óssea pelas bordas do defeito, sendo que o espaçador estava ausente ou presente, quando presente estava em processo de reabsorção envolvido por tecido conjuntivo. O defeito foi preenchido na sua totalidade por tecido conjuntivo (Figura 20). 

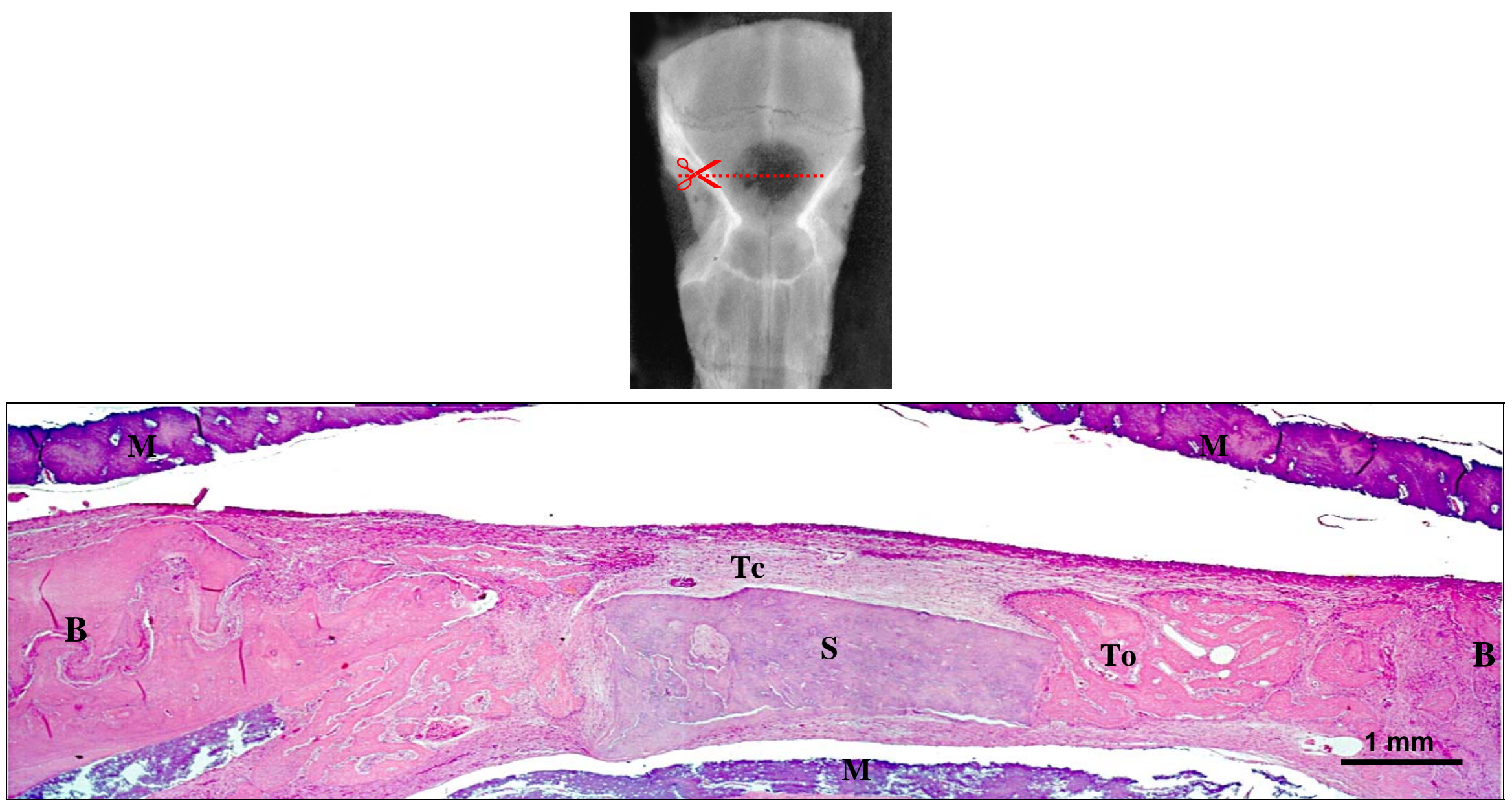

Figura 13. Vista radiográfica e histológica (Experimental 1 mês -Animal g). Observar formação de tecido ósseo (To) entre as bordas (B) e o espaçador ainda íntegro (S), que está circundado por tecido conjuntivo (Tc). Formação óssea associada à membrana (M) que reveste a dura-máter . 

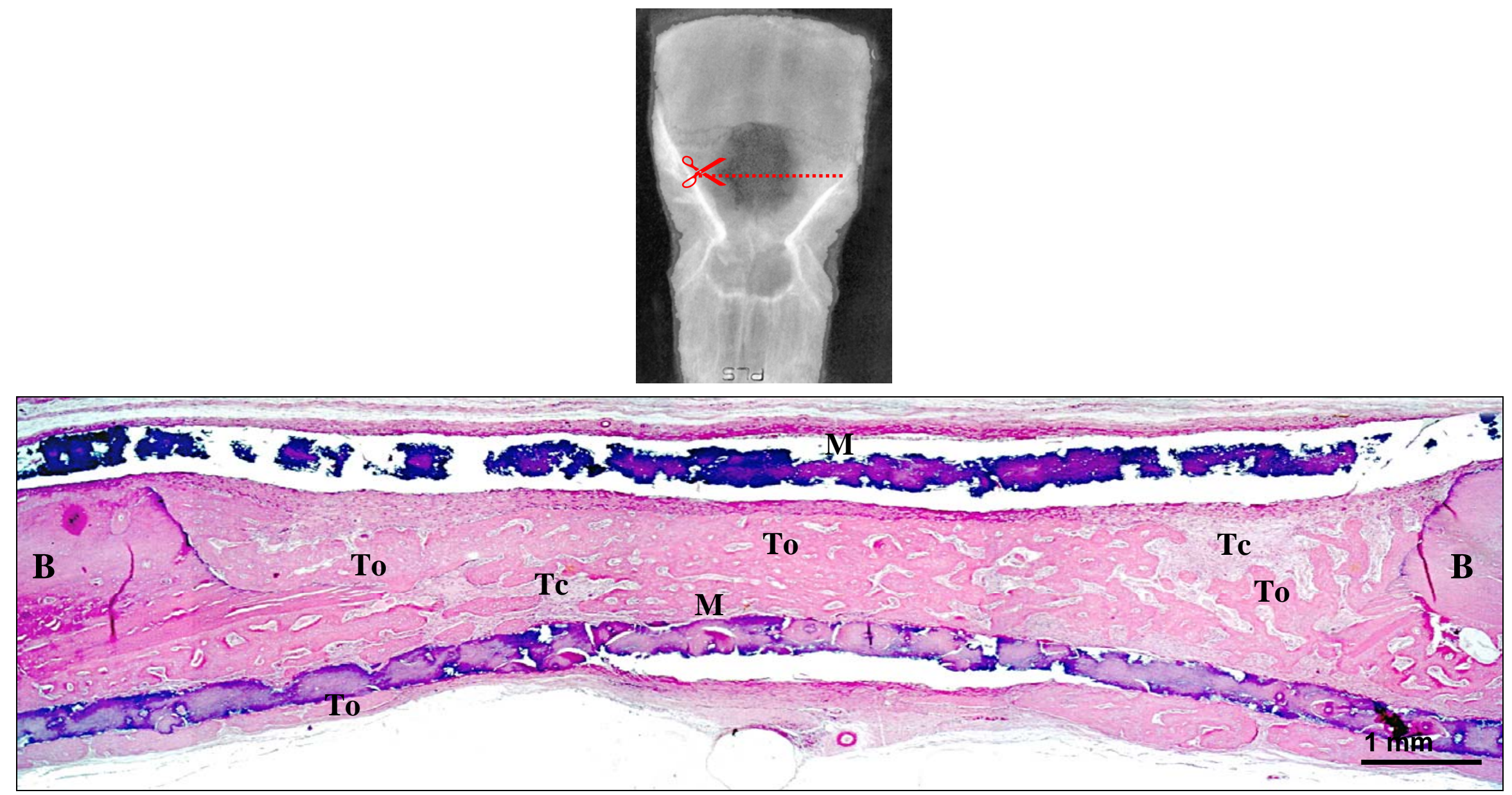

Figura 14. Vista radiográfica e histológica (Experimental 1 mês -Animal i). Observar que a membrana (M) que recobre o defeito está parcialmente reabsorvida e a que reveste a dura-máter está mais íntegra. Formação de tecido ósseo entrelaçado (To) interposto de tecido conjuntivo (Tc). Notar a formação óssea abaixo da membrana que reveste a dura-máter. 

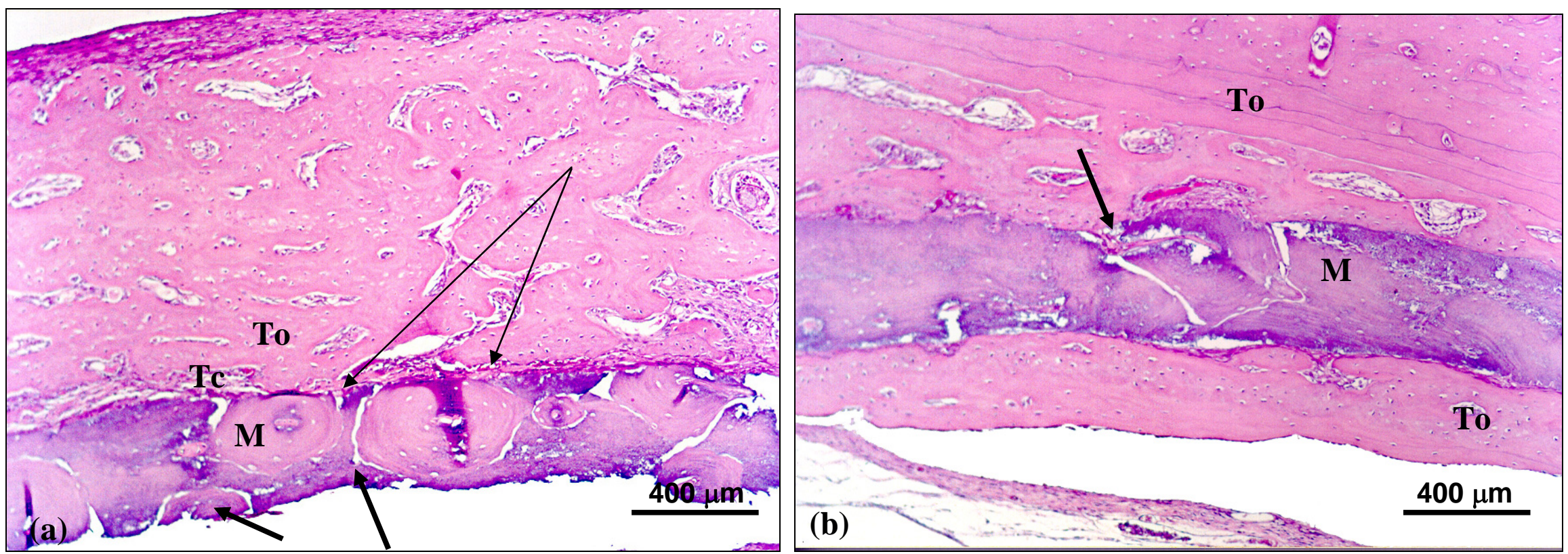

Figura15. Vista histológica (Experimental 1 mês -Animal i). a) Detalhes da membrana (M) na superfície da dura-máter em contato com o tecido ósseo (To) acima, separada por uma fina camada de tecido conjuntivo (Tc), já exibindo sinais de reabsorção na membrana, principalmente na região das lamelas ósseas secundárias (setas); e b) a membrana (M), interposta entre o tecido ósseo neoformado apresentando pequenas áreas de reabsorção (seta). 

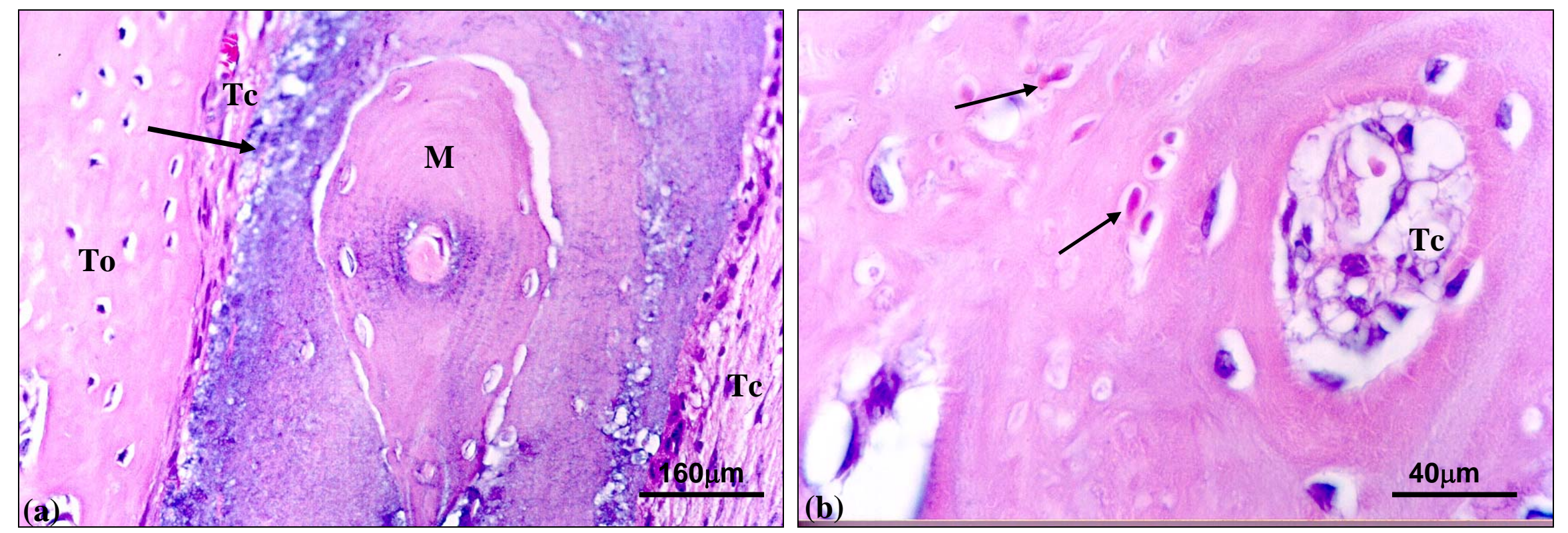

Figura 16. Vista histológica (Experimental 1 mês -Animal i). a). Detalhes da figura anterior exibindo sinais de reabsorção na superfície da membrana (seta) por células mononucleadas. Observar a presença de uma fina camada de tecido conjuntivo (Tc) separando a membrana (M) do tecido ósseo neoformado (To); b) tecido ósseo neoformado apresentando canais preenchidos por tecido conjuntivo (Tc) e hemácias (setas) aprisionado no interior da matriz. 


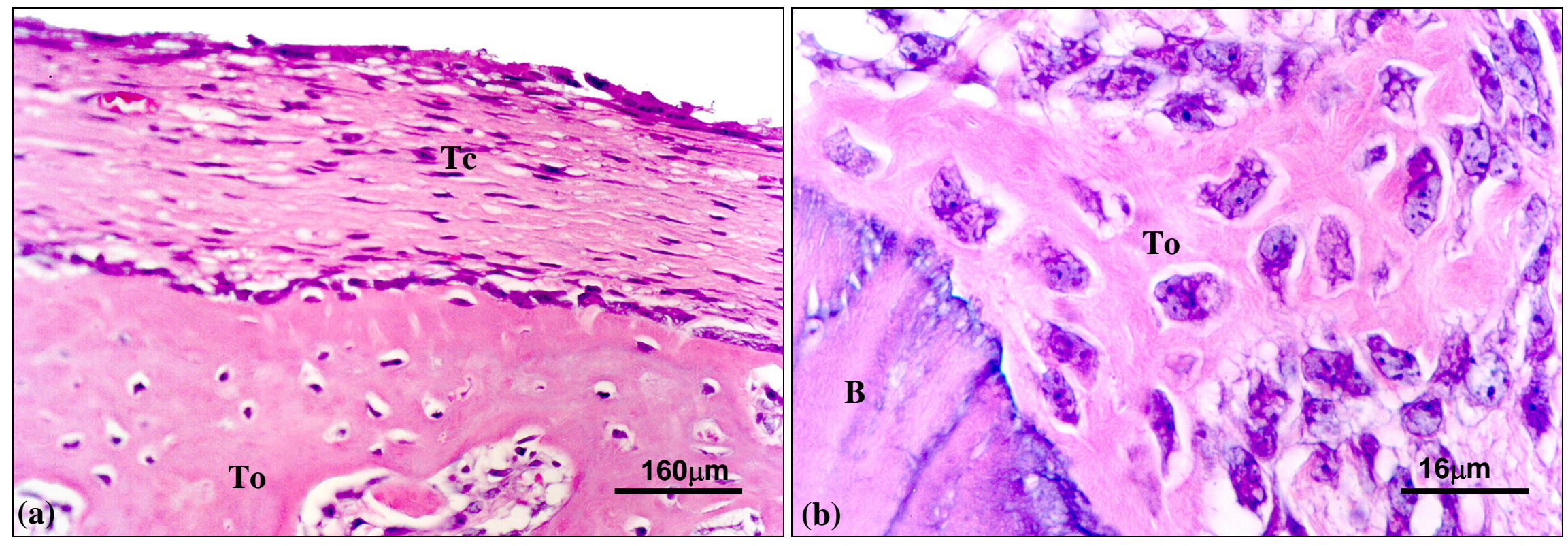

Figura 17. Vista histológica (Experimental 1 mês -Animal i). a) Detalhe da superfície periostal do defeito exibindo tecido conjuntivo (Tc) em íntimo contato com o tecido ósseo (To) neoformado já exibindo características de periósteo; e b)Detalhe da neoformação óssea (To) próximo, à borda do defeito (B). 


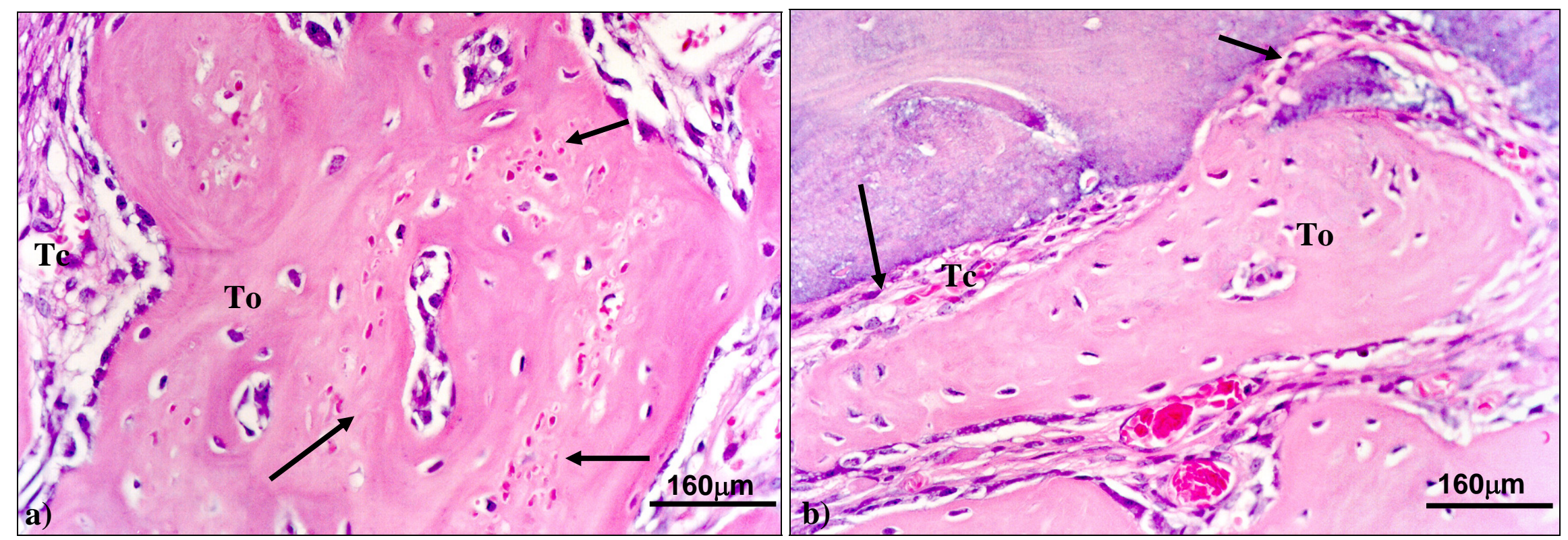

Figura 18. Vista histológica (Experimental 1 mês -Animal i). a) Detalhe do tecido ósseo neoformado (To) que preenche a área do defeito com inúmeras hemácias (setas) provenientes do coágulo sangüíneo aprisionadas no interior da matriz óssea; e b) Detalhes da figura anterior da membrana exibindo sinais de reabsorção na superfície (seta) por células mononucleadas. Observar a presença de uma fina camada de tecido conjuntivo (Tc) separando a membrana do tecido ósseo neoformado (To). 

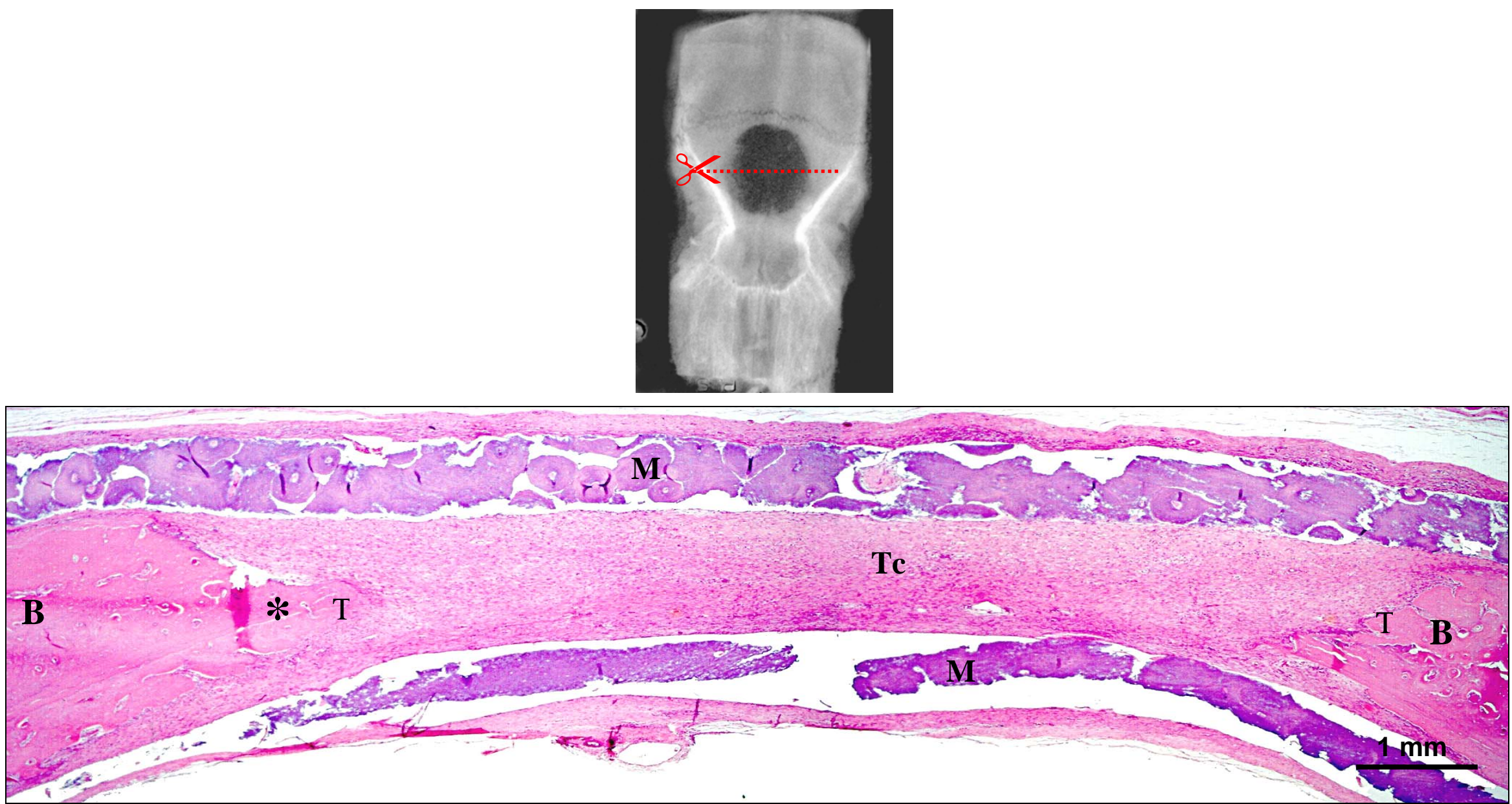

Figura 19. Vista radiográfica e histológica (Experimental 1 mês -Animal j). Observar que a área do defeito está preenchida por tecido conjuntivo (Tc) devido à rápida reabsorção do espaçador. Pequena formação óssea nas bordas do defeito (asterisco). Membrana (M) que recobre o defeito está íntegra, enquanto que a membrana que recobre a dura-máter está parcialmente reabsorvida. 

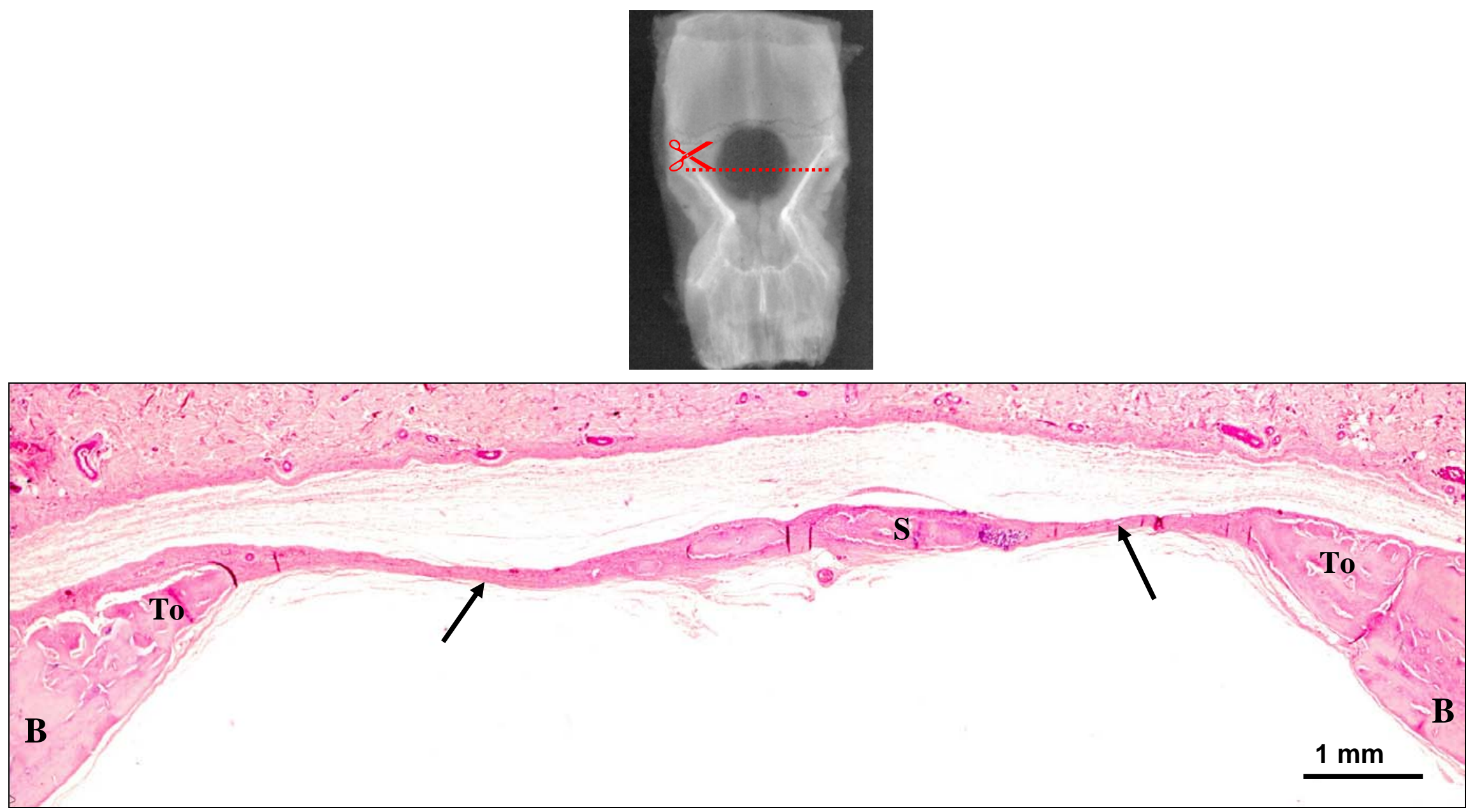

Figura 20. Vista radiográfica e histológica (Controle 1mês -Animal b). Observar que a área do defeito está preenchida por fino tecido conjuntivo fibroso (seta). Pequena formação óssea nas bordas do defeito (To).Presença de fragmentos do espaçador (S), sofrendo processo de reabsorção e envolto pelo tecido conjuntivo. 
O período de 3 meses apresentou restos da membrana, na região periostal, envoltas por tecido conjuntivo apenas em 2 animais (Figura 21). Já na região da dura-máter, os restos da membrana mostraram-se aprisionados por tecido ósseo (Figura 22a). No interior do defeito, ocorreu o preenchimento por tecido ósseo de menor espessura que a do tecido original, formando ilhas ósseas compactas isoladas por uma fina camada de tecido conjuntivo fibroso (Figura 22b). Neste período, a borda óssea apresentou-se remodelada e fusionada com o tecido ósseo que preenchia o defeito, dificultando a visualização do seu limite. A região central do defeito exibiu restos do espaçador envoltos por tecido ósseo e/ou conjuntivo fibroso (Figura 23a), sendo esta região caracterizada por uma falha ou depressão ocupada por tecido mole (Figura 23b).

Em outros dois animais (Figura 24), a membrana na região periostal mostrou-se íntegra com início do processo de reabsorção (Figura 25a, b), enquanto, na região da dura-máter, os restos de membrana encontraram-se aprisionados no interior do tecido ósseo neoformado (Figura 26a, b). Já o interior do defeito mostrou-se preenchido por tecido ósseo semelhante ao do quadro histológico descrito anteriormente, porém o tecido conjuntivo que envolve as ilhas ósseas se mostrou mais espesso, o espaçador estava mais íntegro (Figura 27) e os limites da borda óssea eram nítidos, indicando um atraso no processo de reparo em comparação com o quadro anterior. Num animal, a membrana da região periostal encontrou-se ausente.

O grupo controle de 3 meses apresentou o mesmo quadro histológico do controle de 1 mês. A formação óssea deu-se pelas bordas do defeito, sendo maior quando comparado ao controle de 1 mês. O espaçador, quando presente, se 
apresentou em processo de reabsorção e envolvido por tecido conjuntivo. O defeito foi preenchido na sua totalidade por tecido conjuntivo. Da mesma maneira que no grupo controle, de 1 mês, pôde-se discernir a borda e o tecido ósseo neoformado e também a reformulação da rede sangüínea principal na região da dura-máter (Figura 28). 

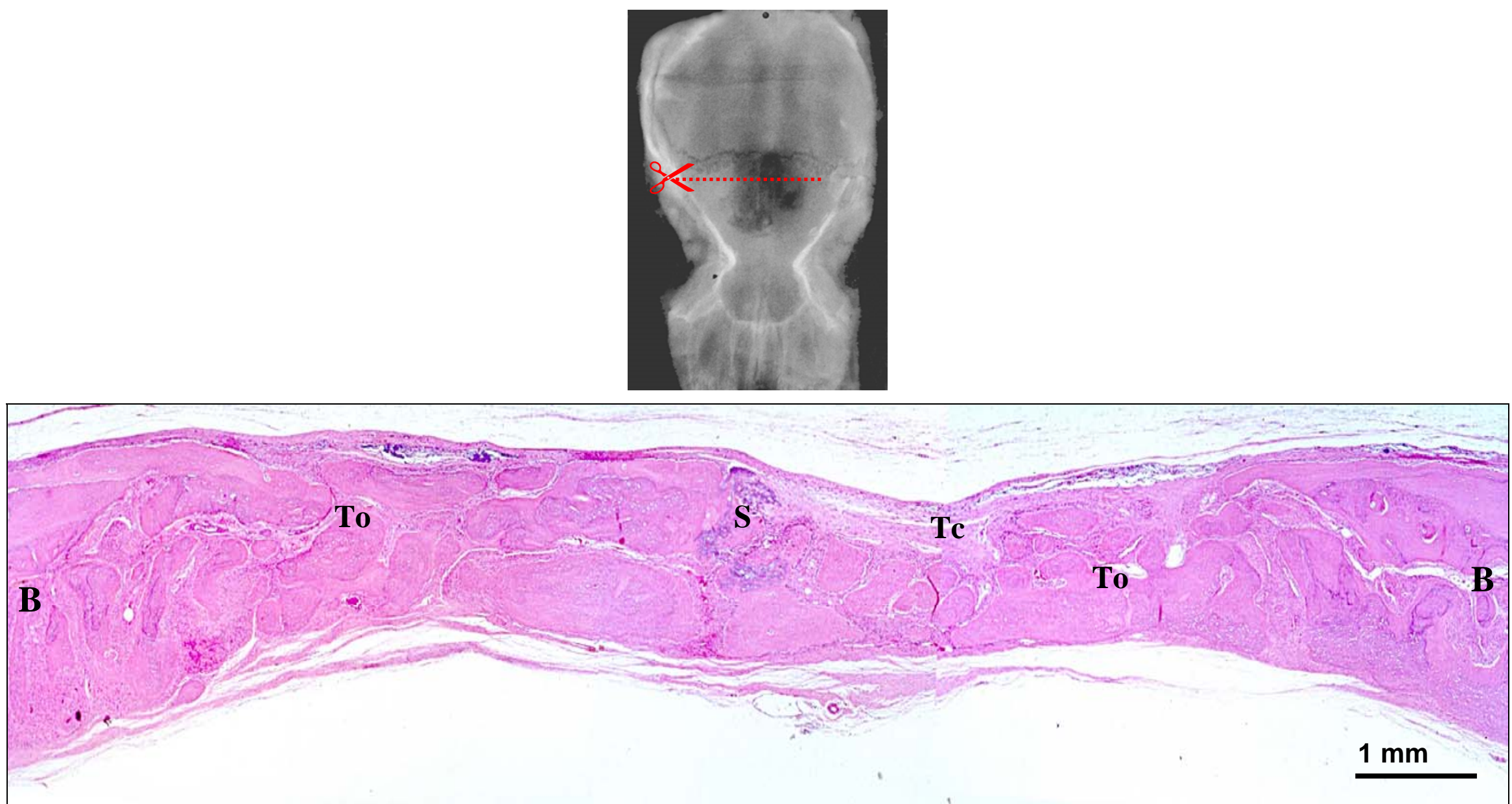

Figura 21. Vista radiográfica e histológica (Experimental 3 meses -Animal j). Observar a área do defeito preenchido por grandes ilhas de tecido ósseo de arranjo compacto (To) com a presença de restos do espaçador (S) e envolvendo as partículas filetes de tecido conjuntivo (Tc) fibroso. 

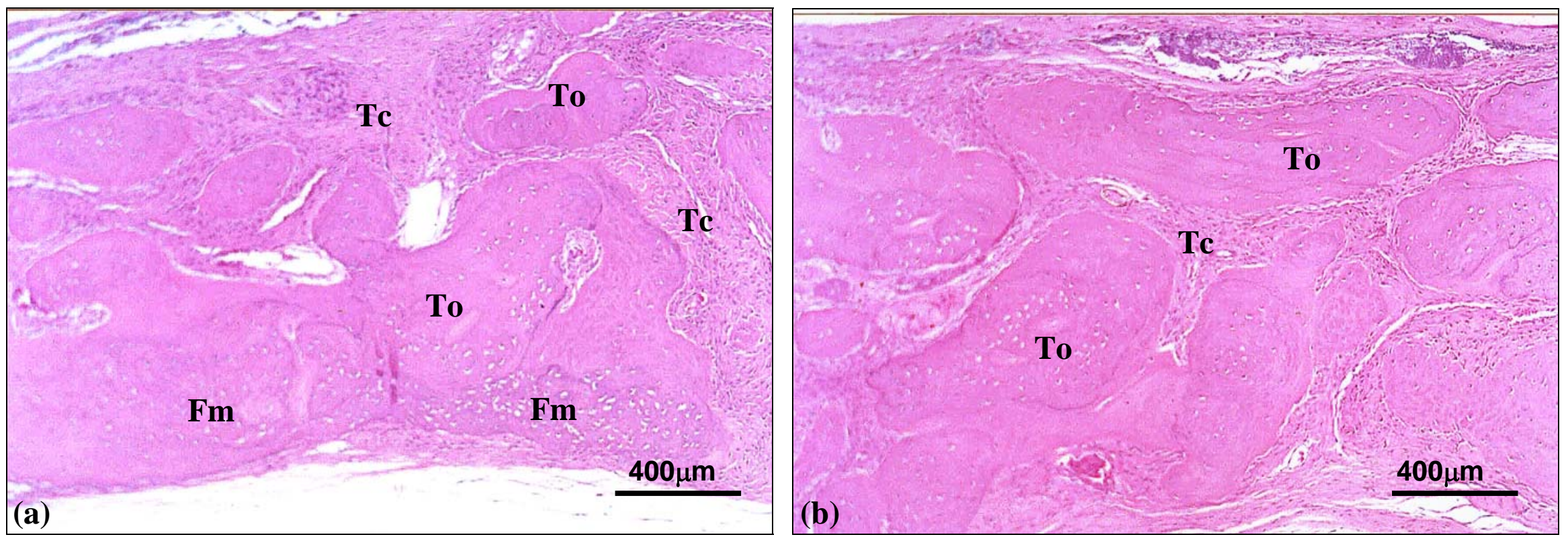

Figura 22. Vista histológica (Experimental 3 meses -Animal j). a) Observar a área do defeito preenchido por grandes ilhas de tecido ósseo de arranjo compacto (To) separadas por uma camada de tecido conjuntivo (Tc) e a presença de fragmentos da membrana da região da dura-máter (Fm) envolvidas por tecido ósseo (To) neoformado. b) Presença de ilhotas ósseas (To) no centro do defeito, separadas por um tecido conjuntivo denso (Tc). 

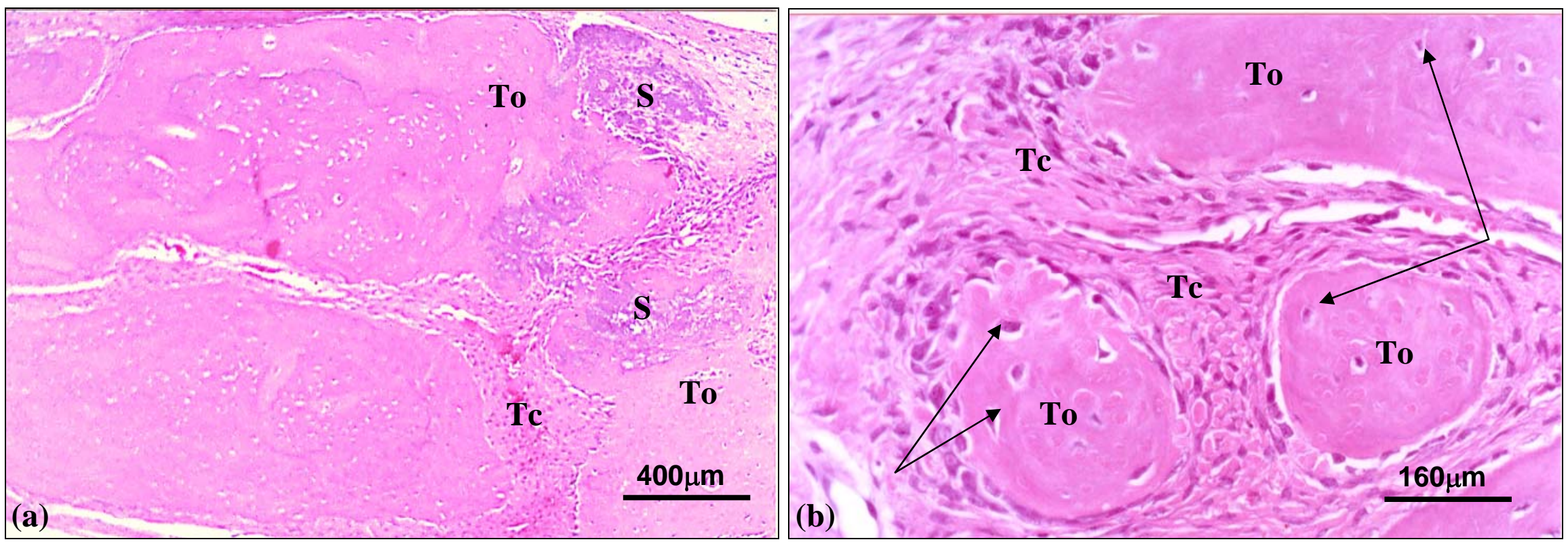

Figura 23. Vista histológica (Experimental 3 meses -Animal j). a) Observar a presença de restos do espaçador (S) envolvidos por tecido ósseo neoformado (To) e tecido conjuntivo (Tc). b) Vista num aumento maior. Tecido conjuntivo (Tc) denso, separando as ilhotas de tecido ósseo neoformado (To) e inúmeras células aprisionadas no interior da matriz neoformada (seta). 

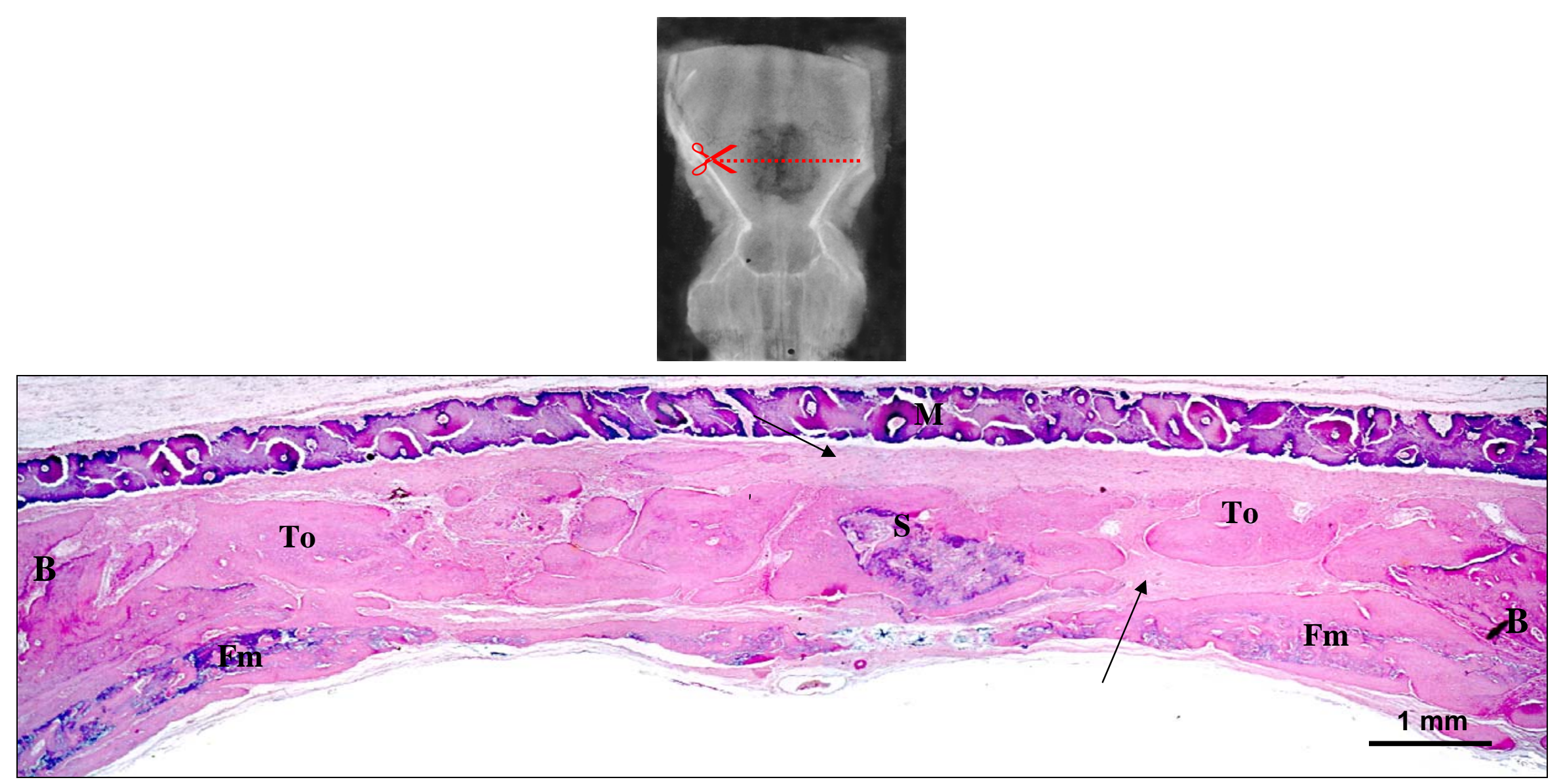

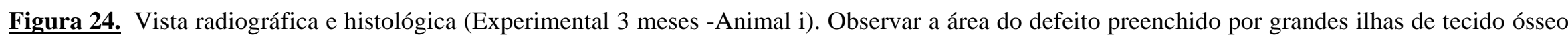
(To) com a presença de restos do espaçador (S) e envolvendo as partículas filetes de tecido conjuntivo fibroso (setas). Observar a presença da membrana acima do defeito e os fragmentos da membrana (Fm) que revestia a dura-máter associada à formação óssea. 

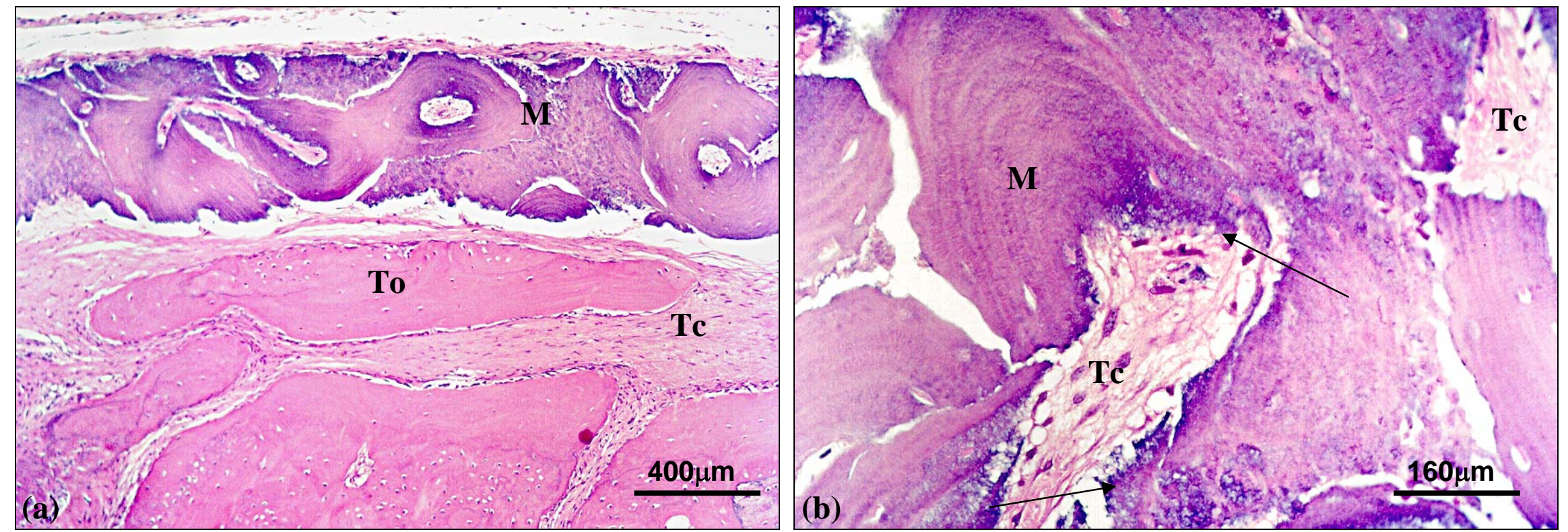

Figura 25. Vista histológica (Experimental 3 meses -Animal i). Detalhes da figura anterior: a) Membrana (M) sendo reabsorvida com a presença de formação de ilhotas de tecido ósseo (To) interposta por tecido conjuntivo denso (Tc). Observar a estrutura da membrana com seus canais harvesianos; b) Vista mais próxima da membrana com sinais de reabsorção (setas) e tecido conjuntivo (Tc) invaginado principalmente nas lamelas secundárias. 


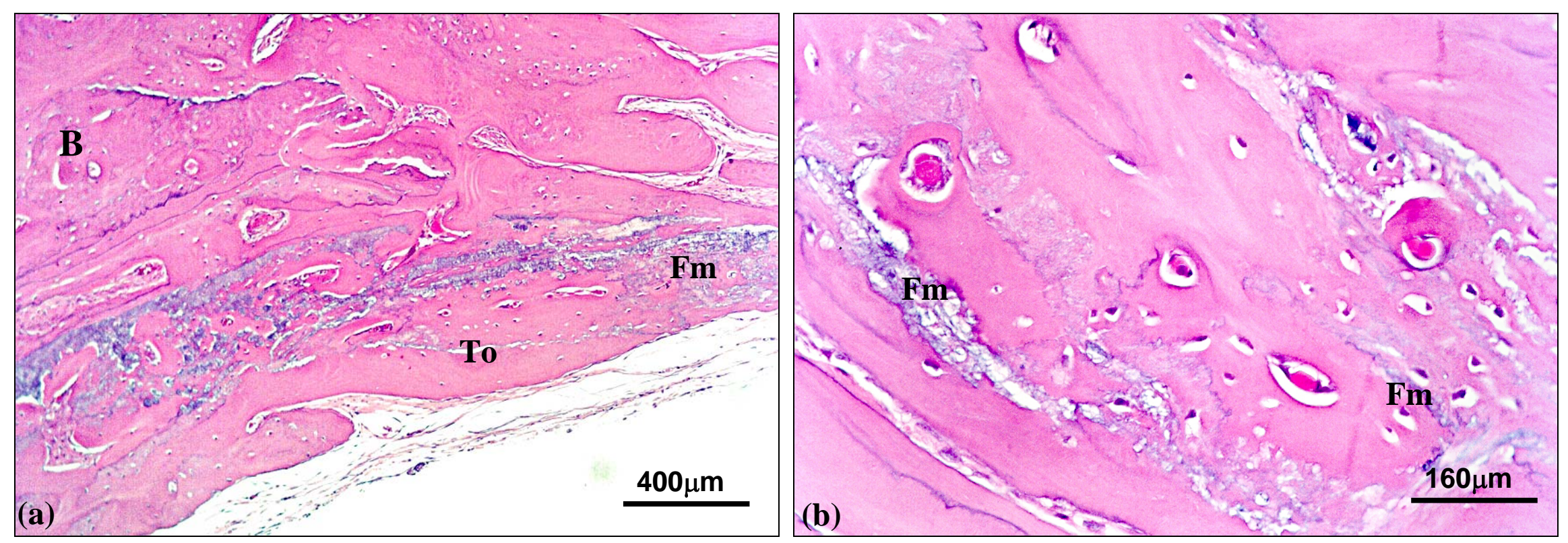

Figura 26. Vista histológica (Experimental 3 meses -Animal i). a) Presença de fragmentos da membrana (Fm) que recobria a região da dura-máter associada à formação de tecido ósseo (To); e b) Vista mais próxima exibindo osso jovem em contato com fragmentos da membrana. 


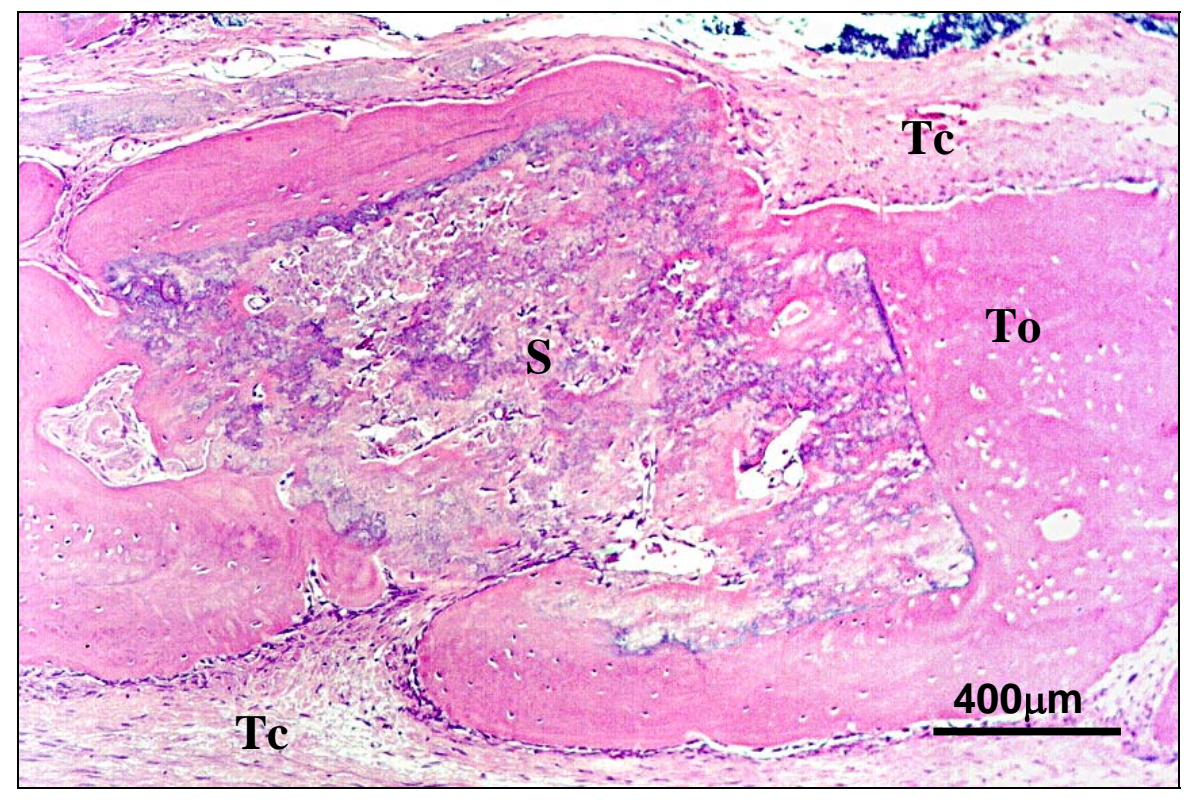

Figura 27. Vista histológica (Experimental 3 meses -Animal i). Detalhe do espaçador (S) sendo reabsorvido associado a neoformação óssea (To) circundado por tecido conjuntivo (Tc). 

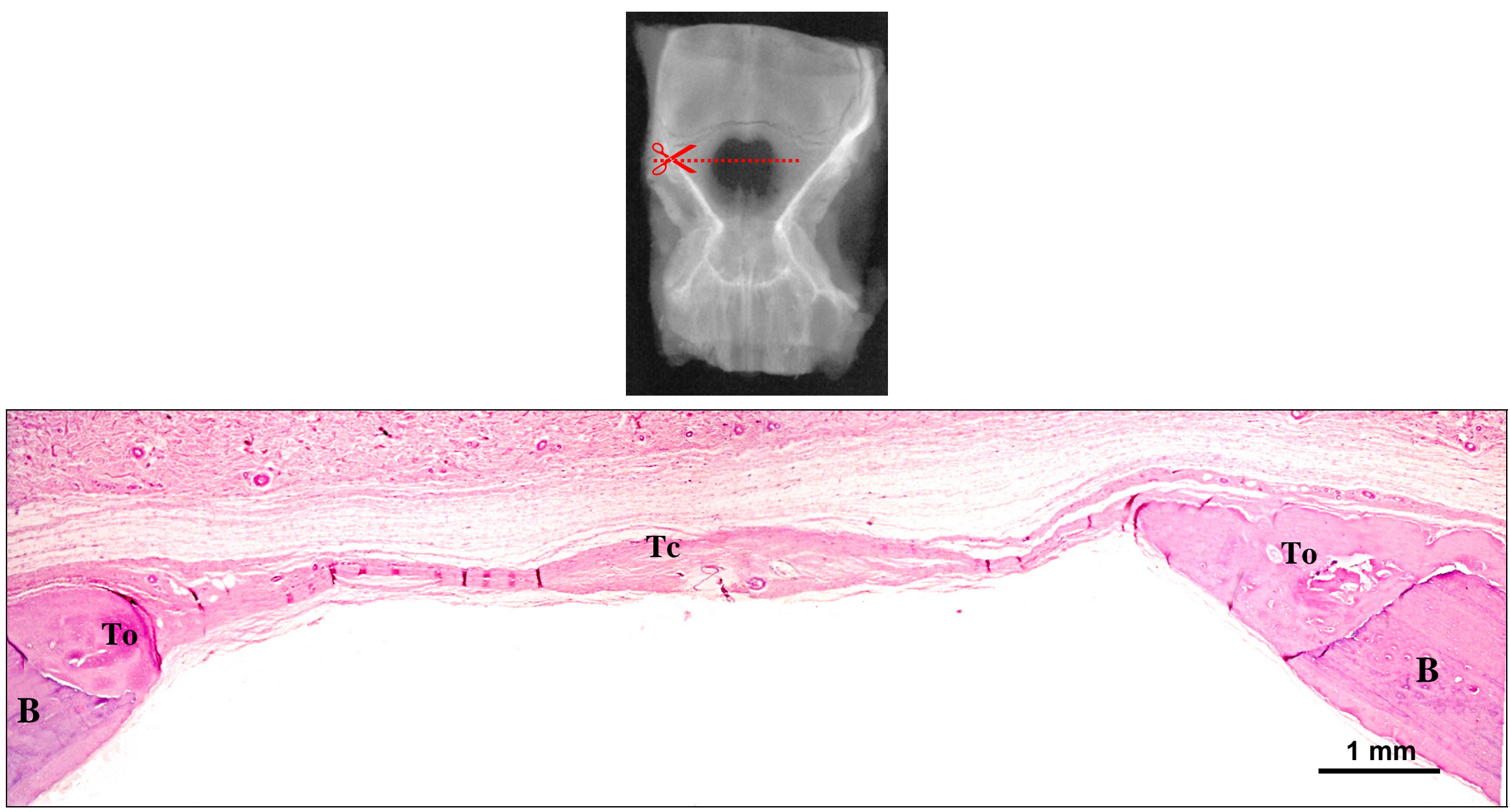

Figura 28. Vista radiográfica e histológica (Controle 3 meses -Animal e). Observar que a área do defeito está preenchida por tecido conjuntivo (Tc). Pequena formação óssea nas bordas do defeito (To). Ausência do suporte. Notar a presença da rede sangüínea logo abaixo do tecido conjuntivo. 
No período experimental de 6 meses, ocorreram dois quadros histológicos. O primeiro quadro, observado em 3 animais, mostrou que a membrana que recobria o defeito se mostrava íntegra, ou parcialmente reabsorvida por células mononucleadas (Figura 30), enquanto a membrana localizada na região da dura-máter estava totalmente ausente ou apresentava fragmentos aprisionados no interior do tecido ósseo neoformado (Figura 29). A área do defeito, num dos casos, mostrou-se preenchida por grandes ilhas de tecido ósseo de arranjo lamelar, tendo no seu interior, espaços preenchidos por tecido mielóide e restos da matriz alogênica implantada, sendo que as ilhas ósseas estavam envoltas por tecido conjuntivo fibroso (Figura 31). Nos outros dois animais, as áreas do defeito estavam preenchidas por um único bloco de tecido ósseo compacto rico em canais medulares (Figuras 31 e 32).

O segundo quadro histológico mostrou ausência da membrana localizada na superfície do periósteo, mas na região da dura-máter foram observados restos de membrana aprisionada no interior do tecido ósseo neoformado. O quadro histológico, na área do defeito, foi semelhante ao do quadro anterior.

O grupo controle apresentou as bordas do defeito bem definidas em relação ao tecido ósseo neoformado. O tecido ósseo formou-se pelas bordas como nos grupos controles anteriores, não ocluindo o defeito. Este se encontrou preenchido por tecido conjuntivo com a ausência do suporte ósseo (Figura 33). 

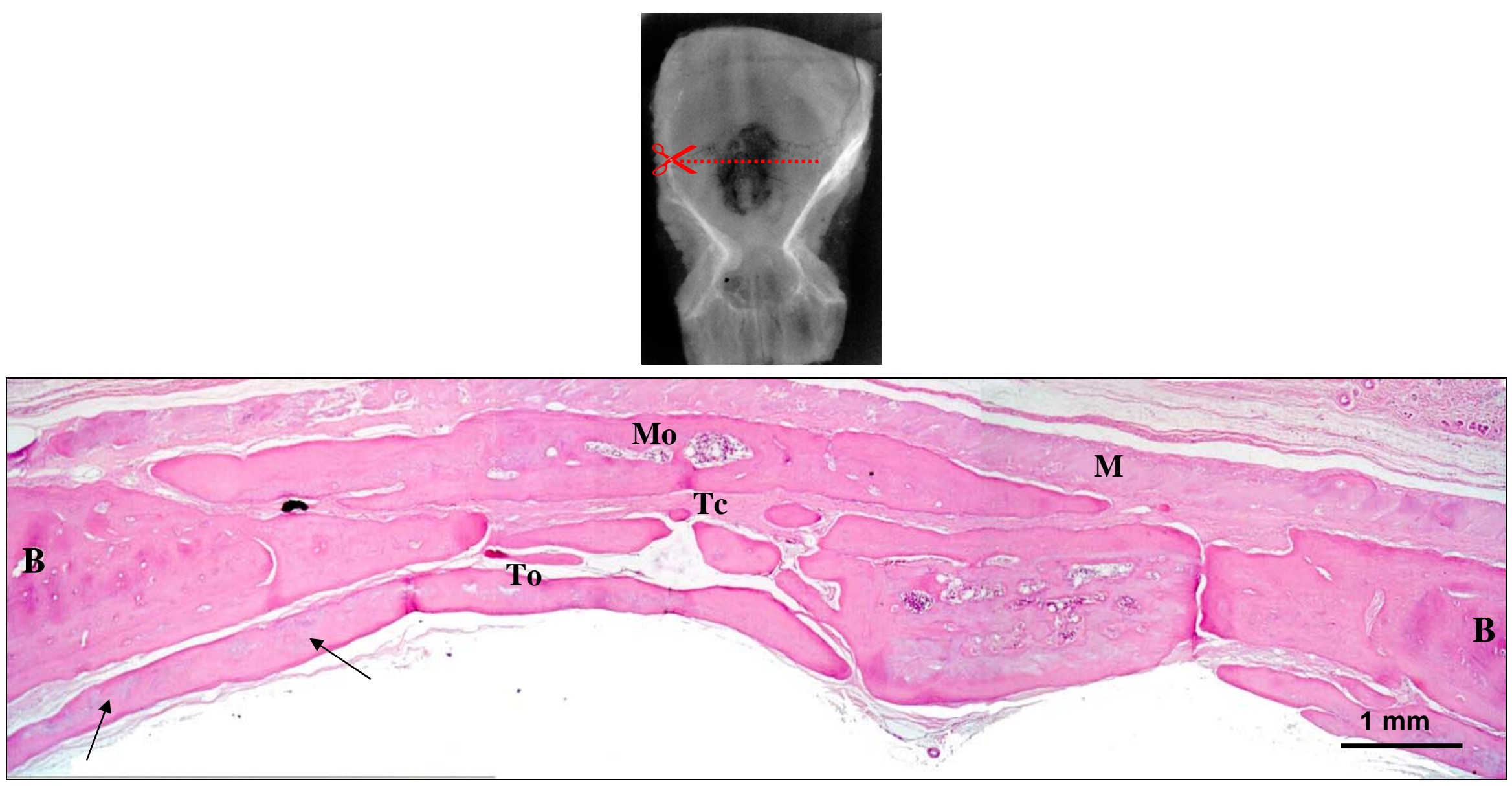

Figura 29. Vista radiográfica e histológica (Experimental 6 meses -Animal h). Observar a área do defeito preenchido por grandes ilhas de tecido ósseo (To) com áreas de medula óssea (Mo) e, envolvendo as partículas, filetes de tecido conjuntivo fibroso (Tc). Observar a presença da membrana (M) acima do defeito e formação óssea associada a restos da membrana que recobria a dura-máter (setas). 


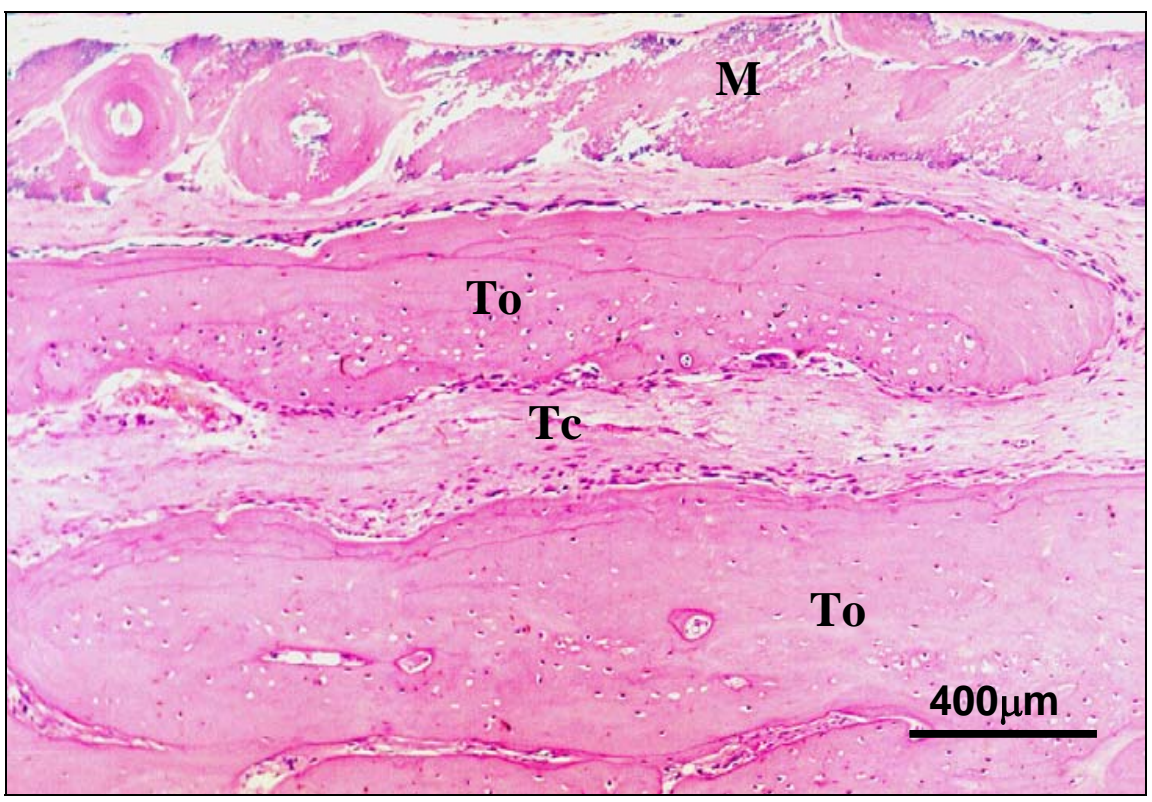

Figura 30. Vista histológica (Experimental 6 meses -Animal h). Detalhes da figura anterior: formação de tecido ósseo (To) abaixo da membrana (M) com tecido conjuntivo fibroso (Tc) ao redor. Observar o processo de reabsorção nas lamelas secundárias da membrana que recobre o tecido ósseo neoformado. 

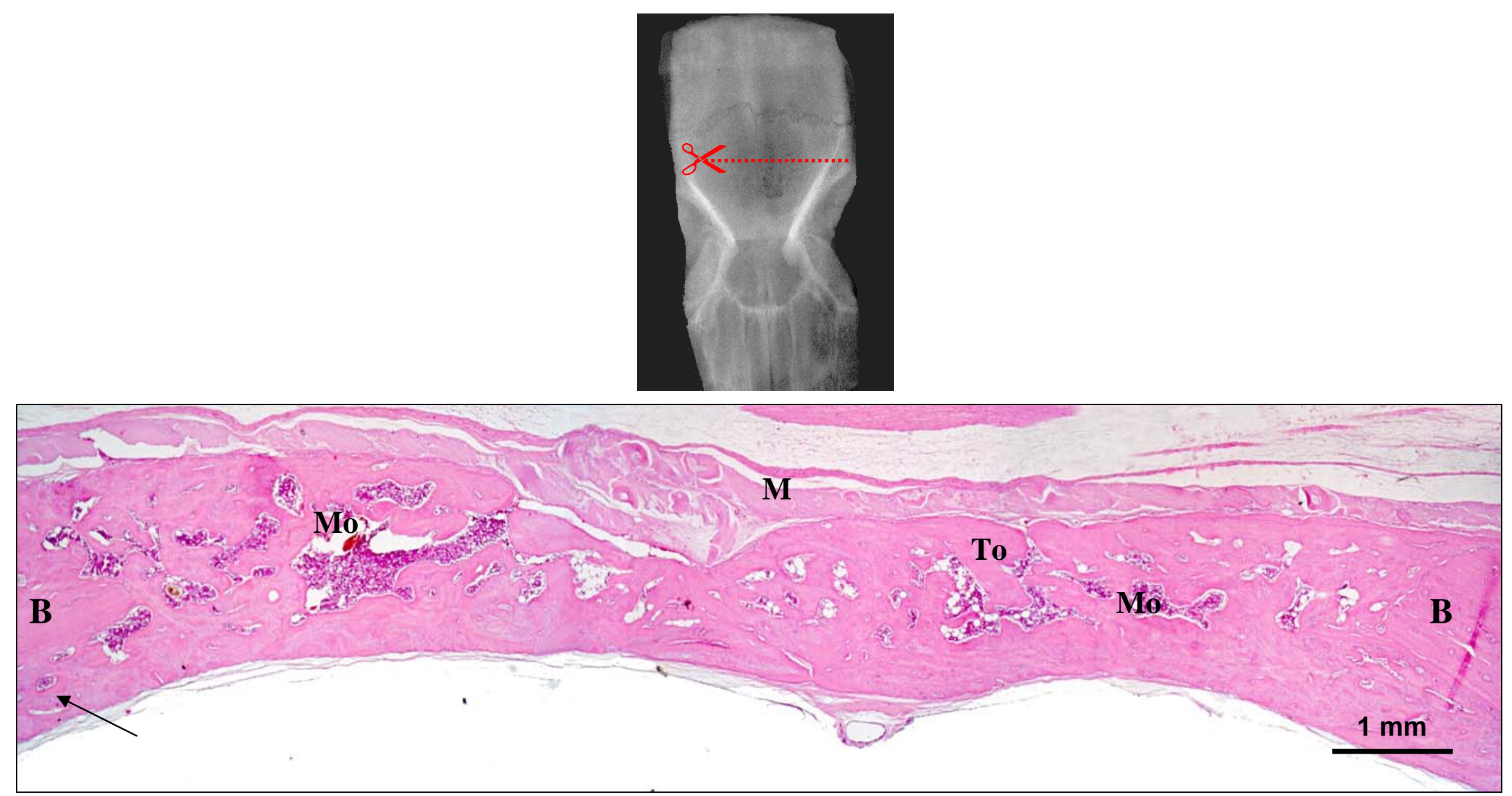

Figura 31. Vista radiográfica e histológica ( Experimental 6 meses -Animal f). Observar a área do defeito totalmente preenchido por tecido ósseo (To) de arranjo compacto, sendo que na região próxima à borda do defeito (B) já exibe em seu interior canais medulares (Mo). Presença da membrana (M) acima do defeito com uma dobra e formação óssea associada a restos da membrana que recobria a dura-máter (Seta). 


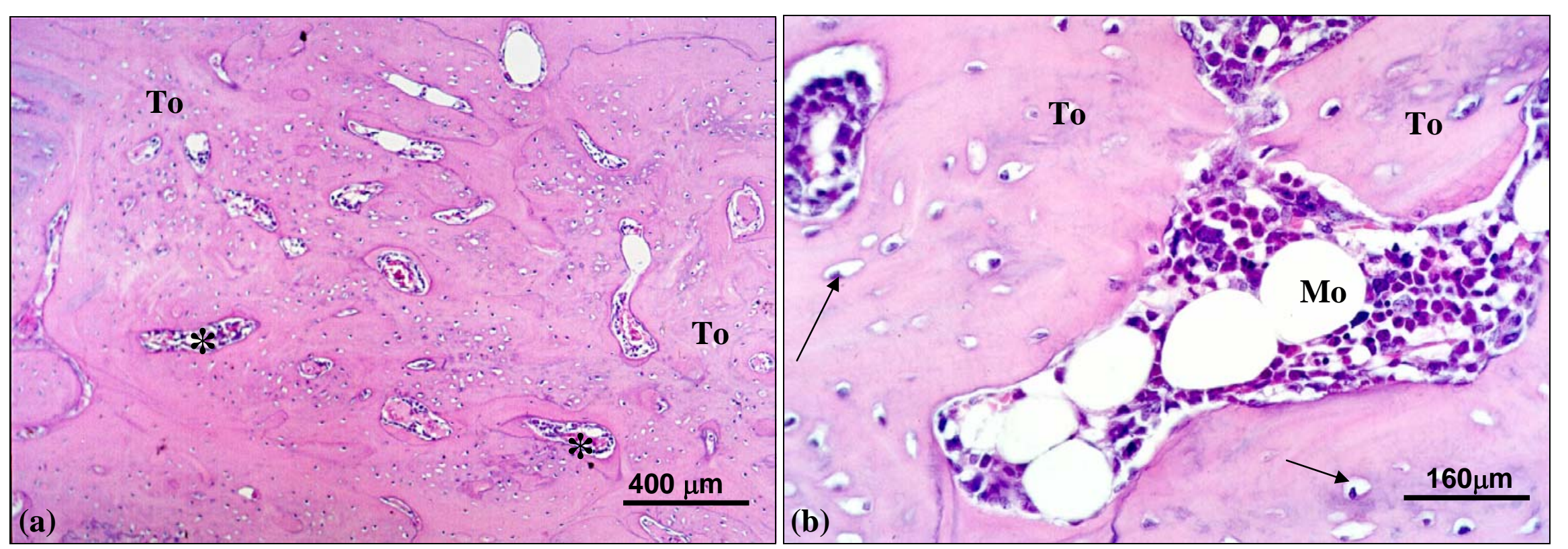

Figura 32. Vista histológica (Experimental 6 meses -Animal g). Detalhes da figura anterior: a) região apresentando tecido ósseo compacto (To) com vários canais medulares (asterisco); e b) região central exibindo tecido ósseo (To) de arranjo trabecular com canais medulares (Mo). Observar a quantidade de células ósseas já aprisionadas no interior do tecido ósseo neoformado (setas). 


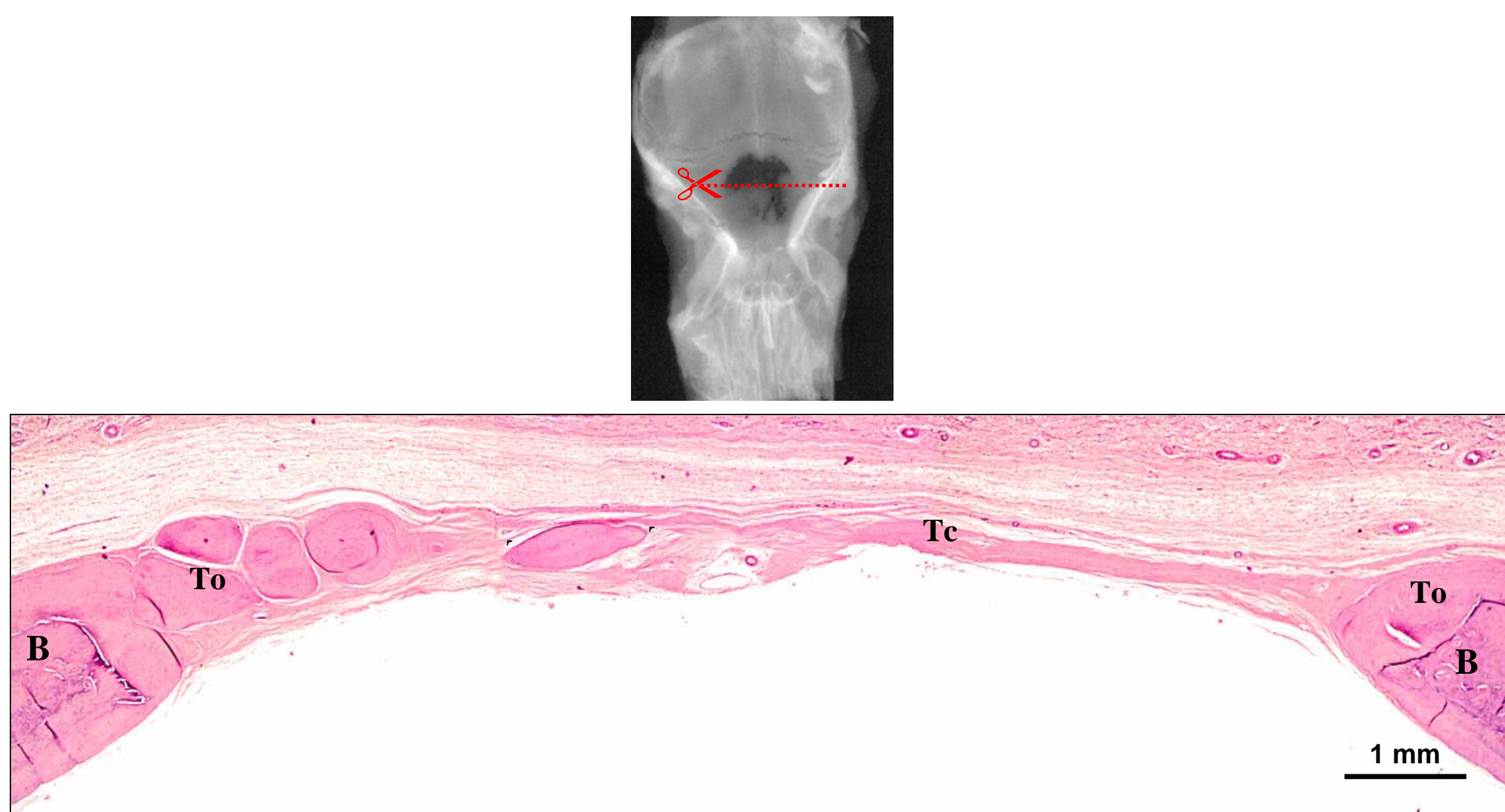

Figura 33. Vista radiográfica e histológica (Controle 6 meses -Animal c). Observar que a área do defeito está preenchida por tecido conjuntivo (Tc) Pequena formação óssea nas bordas do defeito (To). Notar que o limite do defeito está bem definido, diferenciando visualmente as bordas (B) do tecido ósseo neoformado. 
Ao final do período experimental de 9 meses, houve o completo fechamento do defeito em três casos e foram observados restos da membrana aprisionados no interior do tecido ósseo neoformado. O tecido ósseo neoformado, em dois casos, mostrou grandes formações ósseas de arranjo lamelar aumentando substancialmente a espessura óssea na região (Figuras 34 e 35). As ilhas ósseas apresentaram-se envoltas por filetes de tecido conjuntivo e exibiram canais preenchidos por tecido mielóide (Figura 36a e b). Num único caso, o defeito mostrou-se preenchido por tecido ósseo de arranjo lamelar característico da região (Figura 37). Na região das bordas do defeito, houve a presença de tecido mielóide (Figura 38a e b).

A membrana encontrou-se totalmente ausente em dois animais estando o defeito preenchido por tecido ósseo oriundo das bordas do defeito e uma região central ocupada por tecido conjuntivo fibroso (Figura 39).

No grupo controle de 9 meses, não houve muita diferença em relação aos grupos controles anteriores. Em 4 casos, presenciou-se tecido ósseo neoformado na região das bordas do defeito, sendo que o centro do defeito foi preenchido por tecido conjuntivo (Figura 40). Num caso, houve formação óssea pelas bordas e substituição do espaçador por osso neoformado (Figura 41), havendo, entre a borda e a ilhota óssea central, tecido conjuntivo (Figura 42). 

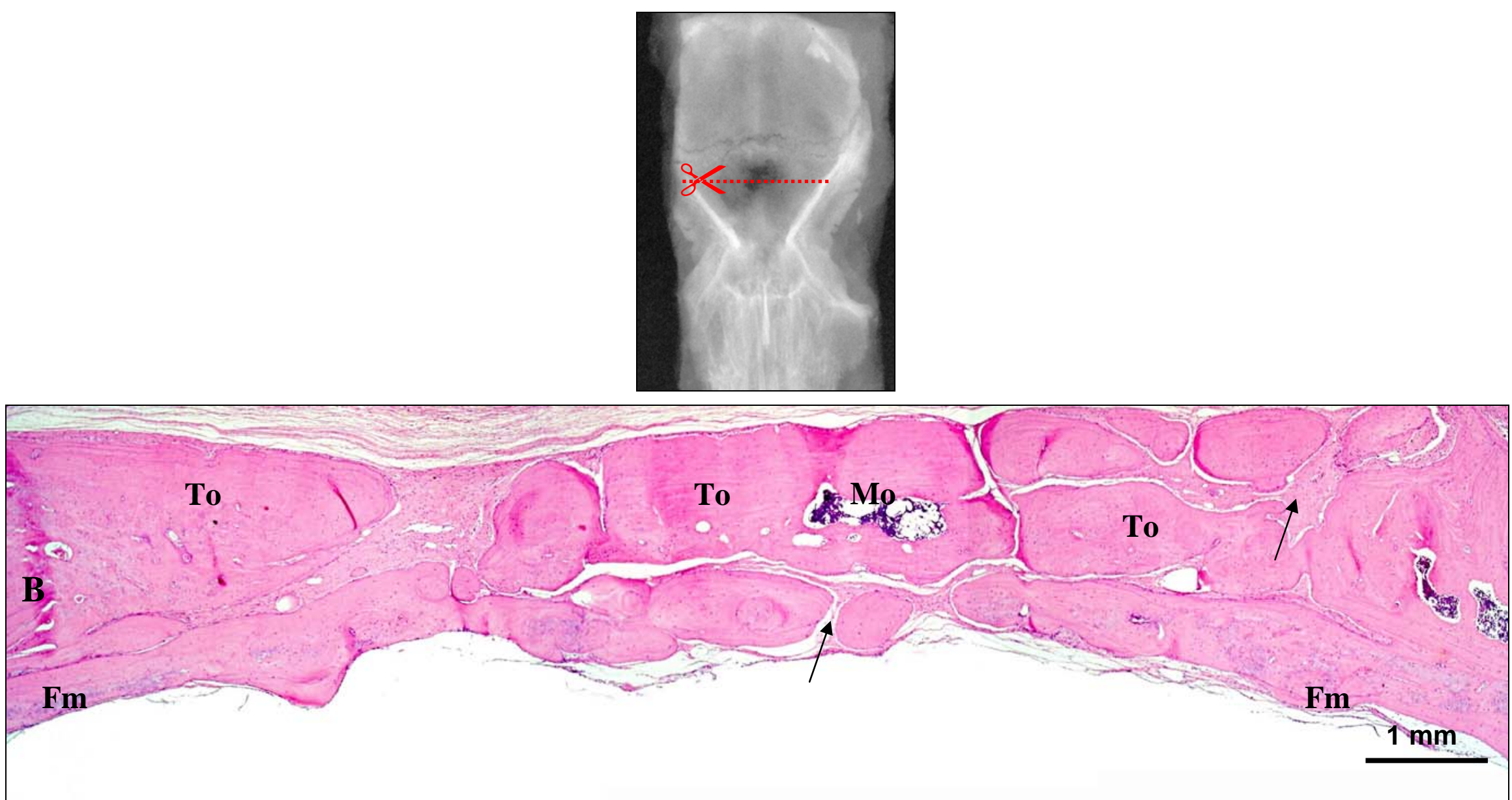

Figura 34. Vista radiográfica e histológica (Experimental 9 meses -Animal f). Observar a área do defeito preenchido por grandes ilhas de tecido ósseo (To) com áreas de medula óssea (Mo) e envolvendo as partículas filetes de tecido conjuntivo fibroso (setas). Notar a formação óssea associada aos fragmentos da membrana (Fm) na região da dura-máter, aumentando a espessura de tecido ósseo na região. 

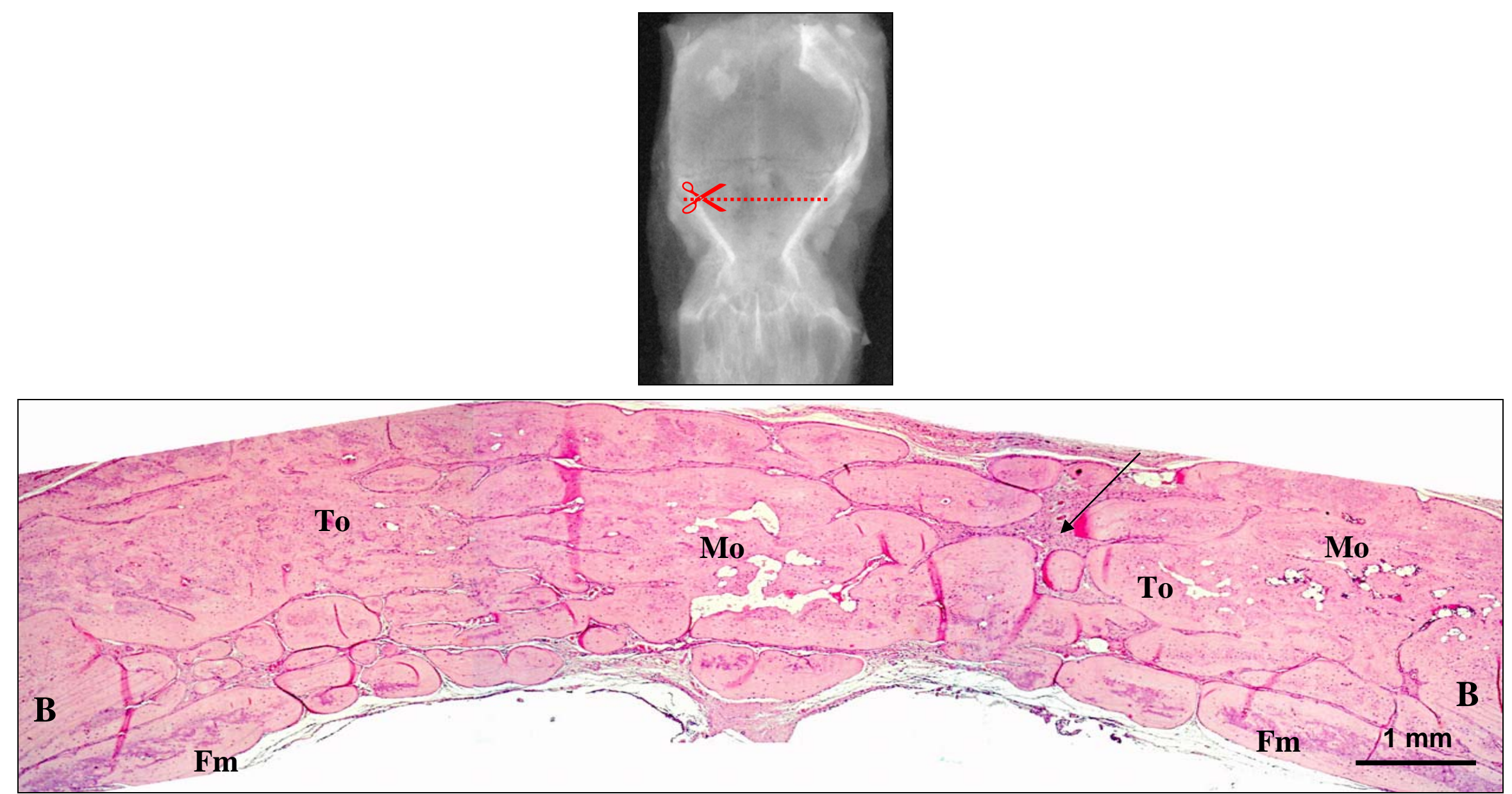

Figura 35. Vista radiográfica e histológica (Experimental 9 meses -Animal j). Observar a área do defeito preenchido por grandes ilhas de tecido ósseo (To) com áreas de medula óssea (Mo) e envolvendo as partículas filetes de tecido conjuntivo fibroso (setas). Notar o aumento do tecido ósseo neoformado, e na região da dura-máter o aumento ósseo associados aos fragmentos da membrana (Fm). 

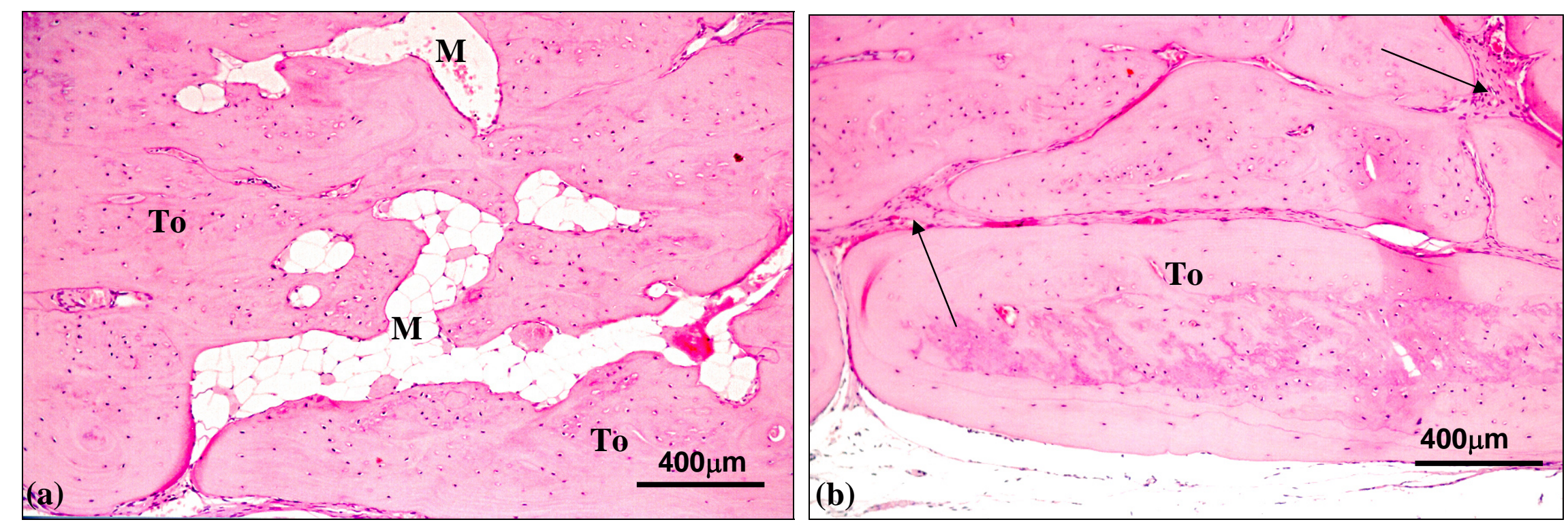

Figura 36. Vista histológica (Experimental 9 meses -Animal g). Detalhes da figura anterior: a) formação de tecido ósseo (To) e de medula óssea (M); e b) região central exibindo tecido ósseo (To) de arranjo compacto separados por pequenos filetes de tecido conjuntivo (seta). Notar a quantidade de células aprisionadas no tecido ósseo neoformado. 

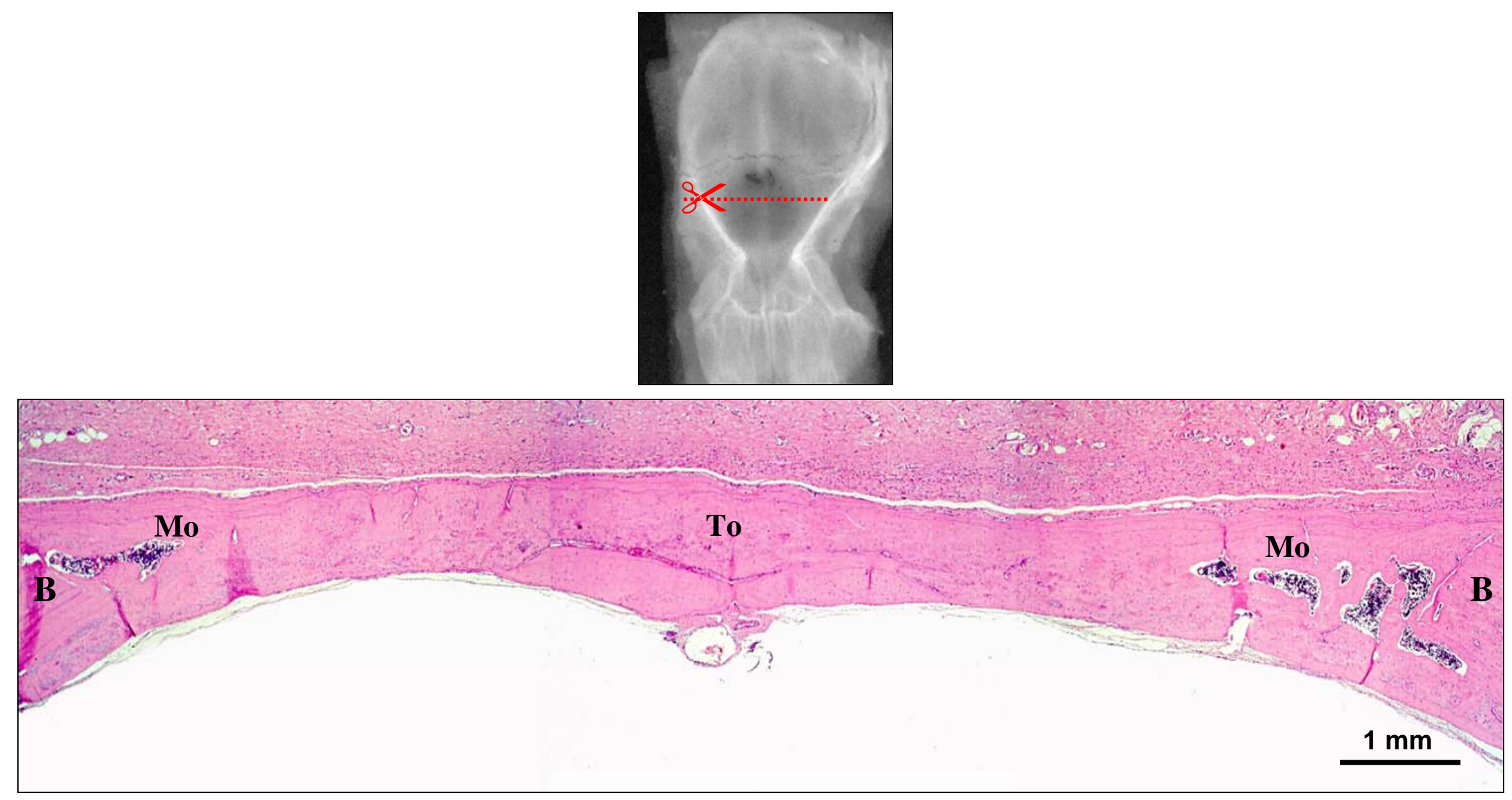

Figura 37. Vista radiográfica e histológica (Experimental 9 meses -Animal g). Observar, neste caso, a área do defeito totalmente preenchido por tecido ósseo (To) de arranjo compacto, sendo que na região próxima a borda do defeito (B) já exibe em seu interior canais medulares (Mo). 

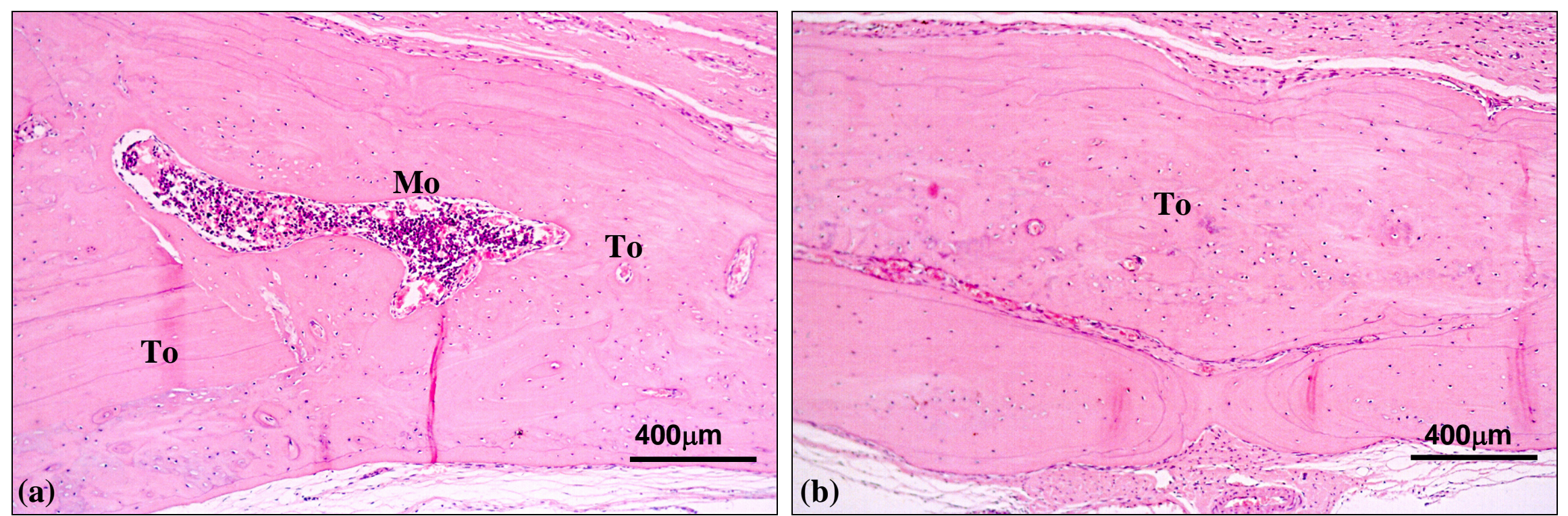

Figura 38. Vista histológica ( Experimental 9 meses -Animal g). Detalhes da figura anterior: a) formação de tecido ósseo (To) e de medula óssea (Mo); e b) região central exibindo tecido ósseo (To) de arranjo compacto. Notar a quantidade de células aprisionadas na matriz. 

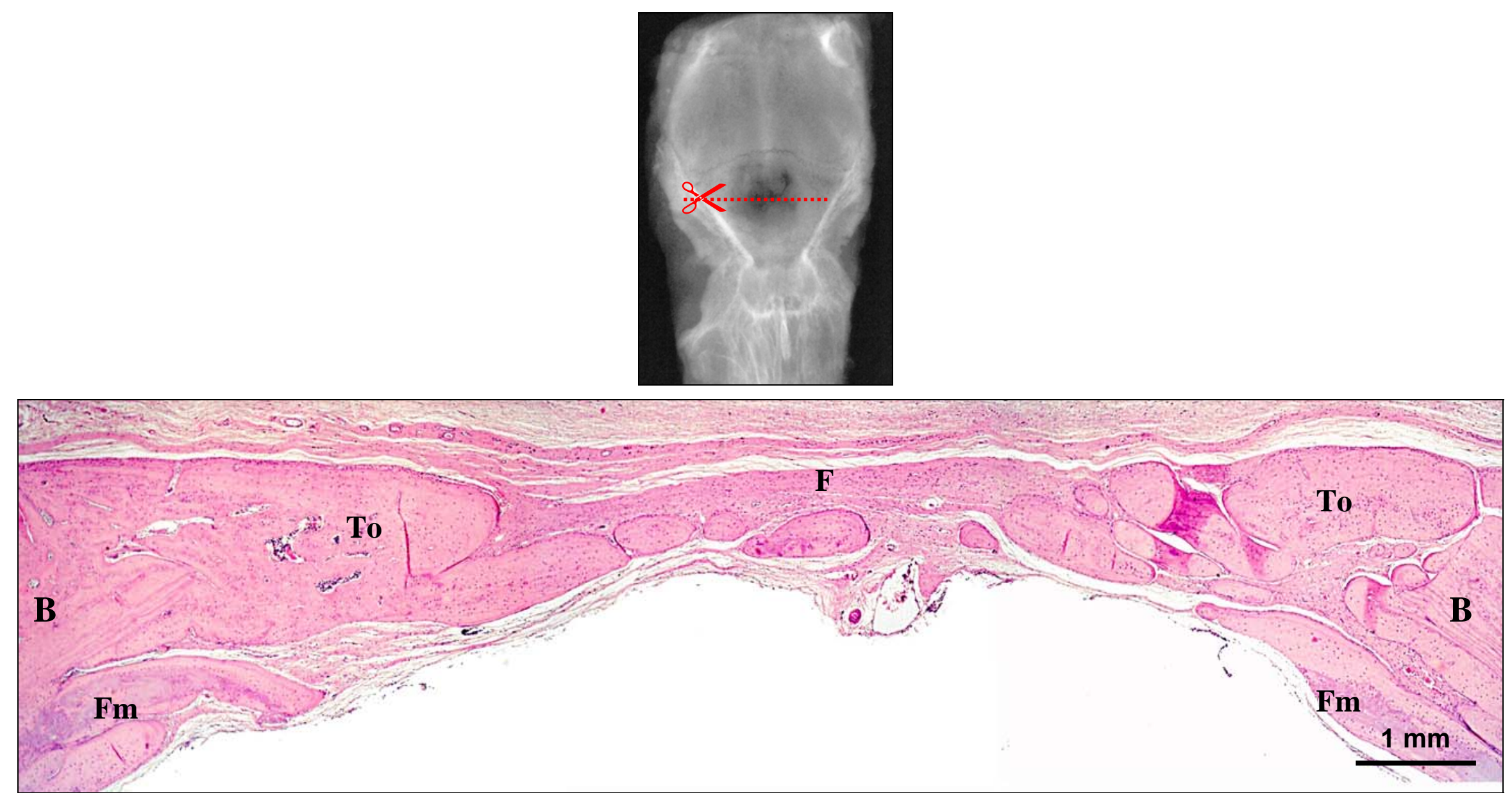

Figura 39. Vista radiográfica e histológica (Experimental 9 meses -Animal j). Observar formação óssea nas bordas (To) com fibrosamento central (f) provavelmente devido à rápida reabsorção do espaçador (suporte). fragmentos da membrana (Fm) estão presentes na região da dura-máter associados à formação de tecido ósseo, abaixo das bordas, aumentando a espessura óssea na região. 

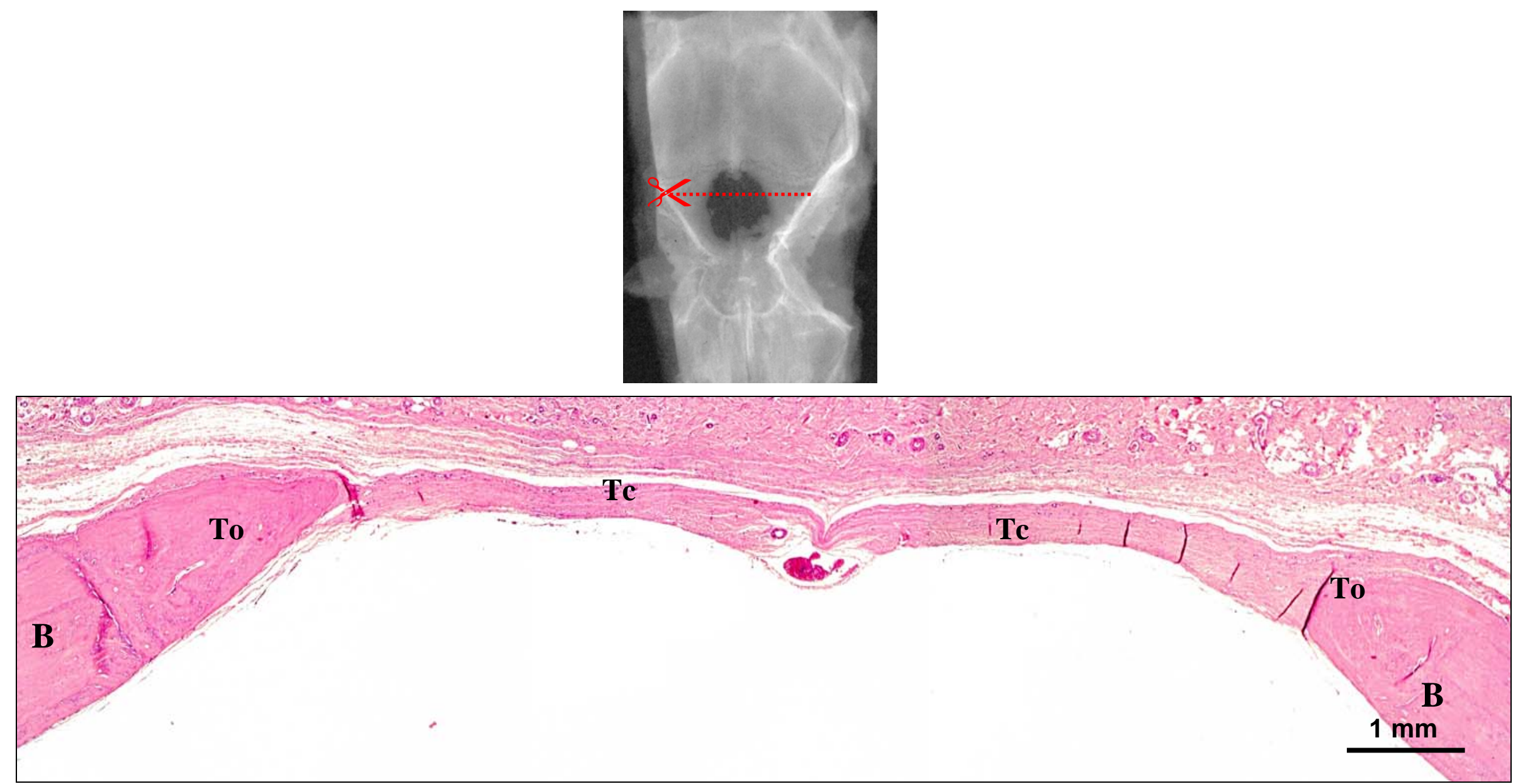

Figura 40. Vista radiográfica e histológica (Controle 9 meses -Animal a). Observar que a área do defeito está preenchida por tecido conjuntivo (Tc). Pequena formação óssea nas bordas do defeito (To). 

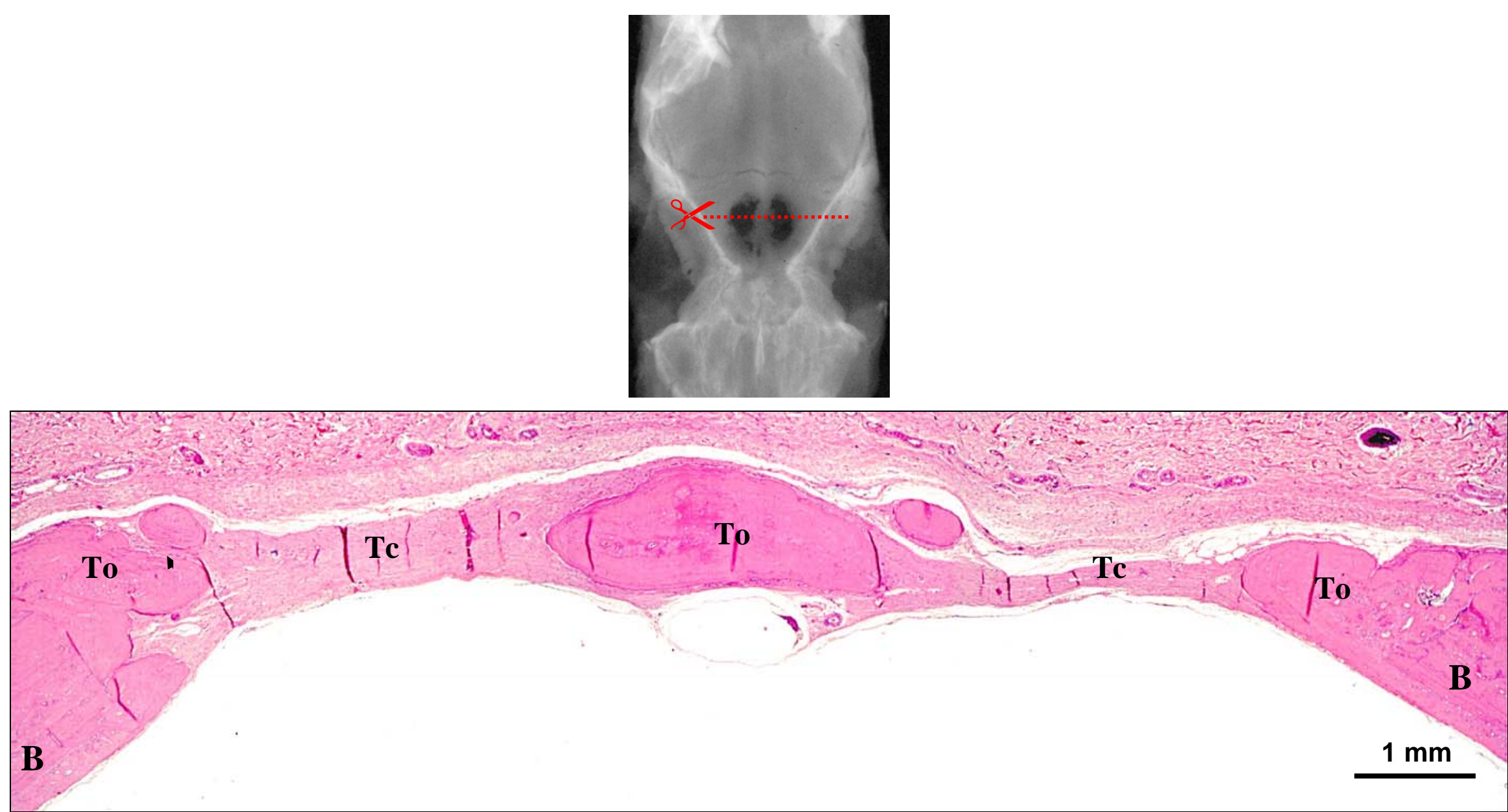

Figura 41. Vista radiográfica e histológica (Controle 9 meses -Animal e).Observar pequena formação óssea nas bordas do defeito (To). Osso neoformado, na região central, circundado por tecido conjuntivo fibroso (Tc). 


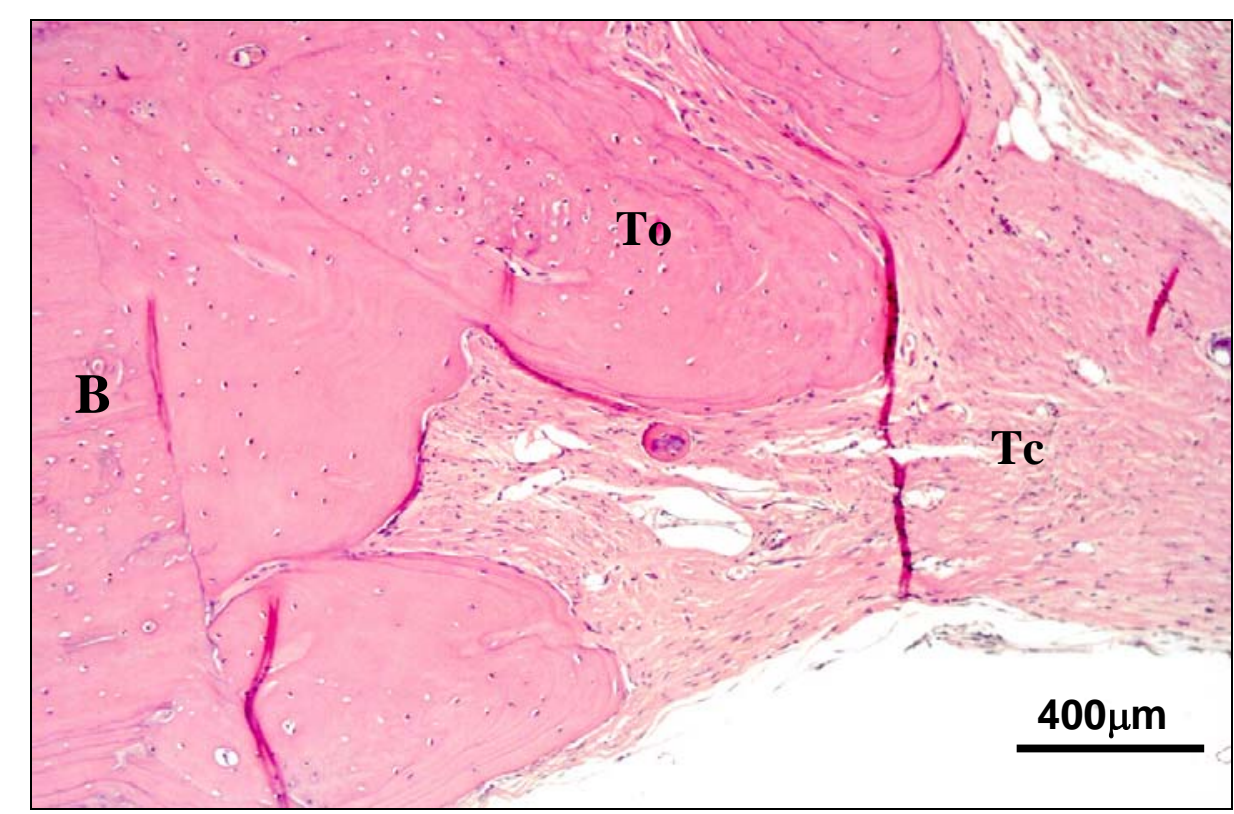

Figura 42. Vista histológica (Controle 9 meses -Animal e). Detalhes da figura anterior. Região de borda (B) com tecido ósseo neoformado (To) e presença de tecido conjuntivo fibroso (Tc) em direção ao centro do defeito. 


\section{DISCUSSÃO}

Sabe-se que a reconstrução de grandes defeitos ósseos é, ainda, um dos maiores desafios para a cirurgia crânio-maxilo-facial e ortopedia. Por isso, é de grande importância que se achem meios de favorecer a sua regeneração. A terapia cirúrgica, utilizando uma barreira ou membrana biológica, é um dos procedimentos que têm proporcionado resultados satisfatórios na regeneração óssea em alguns tipos de defeitos.

Este estudo avaliou morfométrica e histologicamente a capacidade de osteopromoção de uma membrana comercialmente disponível, fabricada com cortical óssea bovina desmineralizada, no tratamento de defeitos críticos, na calvária de cobaias (Cavia porcellus), em períodos de 1, 3, 6 e 9 meses após as cirurgias.

Neste experimento, optou-se por utilizar essa membrana de colágeno estruturada de matriz óssea bovina desmineralizada porque é produzida por uma empresa nacional, de fácil obtenção e custo mais baixo que as similares importadas. O colágeno possui propriedades biológicas que contribuem para a regeneração óssea (RIPAMONTI; REDDI ${ }^{99}$, 1994; BUNYATARAVEJ; WANG ${ }^{14}$, 2001). Assim, vários estudos já comprovaram a eficiência e a biocompatibilidade de membrana de origem colagênica na osteopromoção e regeneração tecidual guiada tanto em modelos animais (PITARU et al. ${ }^{93}$, 1988; COLANGELO et al. ${ }^{25}$, 1993; SEVOR et al. $^{114}$, 1993; HÜRZELER et al. ${ }^{49}$, 1998; MCGINNIS et al. ${ }^{72}$, 1998; ZAHEDI et al. ${ }^{135}$, 1998; HOCKERS et al. ${ }^{46}$, 1999; OWENS; YUKNA ${ }^{87}$, 2001; BUNYATARAVEJ WANG $^{14}$, 2001) quanto em humanos (ZITZMANN et al. ${ }^{136}$, 1997; PARODI et al. ${ }^{91}$, 
1998; BENQUÉ et al. ${ }^{6}, 1999$ CORTELLINI; TONETTI ${ }^{28}$, 2000; BRUNEL et al. ${ }^{13}$, 2001; BUNYATARAVEJ; WANG, ${ }^{14} 2001$; ZIZTMANN et al. ${ }^{137}$, 2001).

O uso do colágeno para produção de uma membrana ou barreira está baseado nas ótimas características biológicas desta substância (WANG; MACNEIL $^{127}$, 1998; WANG; CAROLL ${ }^{128}$, 2001) e sabe-se que a matriz óssea de colágeno estruturada funciona como um ótimo substrato para o recrutamento e ancoragem de células progenitoras, e conseqüentemente para a proliferação e diferenciação de osteoblastos, bem como para servir de carreador e de proteção para as proteínas morfogenéticas ósseas contra enzimas proteolíticas não específicas, características estas que podem ser uma vantagem adicional para a sua aplicação na terapia periodontal (RIPAMONTI; REDDI ${ }^{99}$, 1994).

SILVERSTEIN; KRAFT; WAND $^{115}$ (1992); CALLAN $^{19}$

YAMAOKA et al. ${ }^{133}$ (1996) relataram que da cortical óssea humana é possível conseguir membranas de colágeno tipo I com ótimas propriedades biológicas, no entanto foi escolhido o osso bovino como matéria prima para obtenção das membranas de colágeno em virtude da dificuldade de obtenção de osso humano em quantidade suficiente, por causa do alto custo da manutenção de um banco de ossos e também porque há o impedimento ético legal de comercialização de tecidos humanos no Brasil.

Apesar do sucesso na utilização clínica da membrana de cortical óssea bovina, relatada por profissionais da área e de alguns trabalhos histológicos em modelos animais já publicados sobre a capacidade osteopromotora desta membrana (TAGA et al. ${ }^{119}$, 1997; TAGA et al. ${ }^{120}$, 2000; HERCULIANI et al. $^{45}$, 2000; SANCHEZ et al. $^{103}$, 2000), ainda não há informações sobre seu tempo de 
permanência em atividade e as bases celulares e moleculares envolvidas na resposta biológica a este tipo de membrana e seu papel no reparo ósseo, sendo que foram estas as questões que estimularam a elaboração deste estudo.

$\mathrm{Na}$ atual pesquisa, avaliamos essa membrana em modelo animal de defeito de tamanho crítico em crânio de cobaias (“Cavia porcellus”). Salientamos que modelos animais têm sido utilizados, por várias décadas, em experimentos para testes de medicamentos, materiais cirúrgicos e técnicas de tratamentos. Atualmente, existem modelos animais, criados em condições laboratoriais totalmente padronizados, seguindo condições éticas pré-estabelecidas e aceitos com confiança pela comunidade científica. Baseado em tentativas e erros, levando-se em conta a semelhança das respostas entre humanos e modelos animais surgiram protocolos experimentais adequados para determinados experimentos. Entretanto, os resultados obtidos em modelos animais devem ser analisados com cuidado, já que nem todos podem ser extrapolados diretamente para os humanos. Assim, por exemplo, animais de laboratório de pequeno porte apresentam maior capacidade regenerativa óssea do que em humanos.

Por outro lado, muitos fatores devem ser levados em consideração na avaliação de estudos in vivo. Assim, a quantidade e a qualidade de osso formado num defeito ósseo são influenciadas pela espécie e o tipo de animal utilizado no experimento, sua idade, a estabilidade do defeito, localização anatômica do defeito, tipo de osso e a presença ou ausência do periósteo e a da dura-máter.

Em relação ao uso de cobaias em experimentos de Regeneração Óssea Guiada (ROG), nada foi encontrado na literatura. Grande parte dos trabalhos revistos nesta dissertação, foram realizados com ratos. Talvez isso se deva ao fato de que a 
espécie animal aqui usada tenha prole menos numerosa, período gestacional mais longo e maior dificuldade de manutenção. Em nosso estudo, seguimos todos os requisitos em relação aos animais a serem usados na experimentação relatados por BOSCH; MELSEN; VARGERVIK ${ }^{8}$ (1998), assim houve uma grande disponibilidade de animais no biotério da FOB-USP a um custo de manutenção aceitável, o manejo foi adequado e os procedimentos cirúrgicos foram facilitados pelo tamanho do animal em comparação aos camundongos e ratos. Além do que, na díploe da calvária do rato, não se pode observar a presença de osso medular entre as corticais, enquanto, na cobaia, a díploe é bem definida com duas corticais nítidas e uma camada de osso medular central. A maior espessura da parede óssea, que facilitaria a colocação de dupla membrana, a presença do osso medular, a menor capacidade regenerativa óssea, o maior porte corporal e a alta resistência orgânica às cirurgias, foram os diferenciais para a escolha da cobaia ao invés do rato para o presente experimento.

A utilização da calvária para a realização de defeito de tamanho crítico deveu-se a sua pobre vascularização e relativa deficiência de medula óssea com relação a outros ossos, sendo muito similar à da região maxilo-facial. Embriológica e morfologicamente a calvária desenvolve-se por ossificação intramembranosa à semelhança dos ossos membranosos da face. Anatomicamente, a calvária consiste de duas tábuas corticais delimitando a região medular central semelhante ao osso alveolar. Segundo SCHMITZ; HOLLINGER ${ }^{110}$ (1986), DUPOIRIEUX et al. $^{37}$ (2001) devido às características acima citadas a calvária é o local de eleição para testes de biomateriais e de estudo de Regeneração Óssea Guiada. 
No tocante ao defeito ósseo de tamanho crítico, SCHMITZ; HOLLINGER $^{110}$ (1986) definiram-no como um defeito ósseo cujas dimensões não permitem a regeneração espontânea do tecido ósseo durante o tempo de vida do animal, a não ser que algum tipo de material osteogênico, osteocondutor ou osteoindutor seja colocado dentro ou sobre este defeito. Tais defeitos, quando não tratados, são reparados por tecido conjuntivo fibroso, embora ocorra alguma neoformação óssea nas margens do defeito.

O defeito de tamanho crítico, em calvária, aqui usado atendeu aos requisitos descritos por BOSCH; MELSEN; VARGERVIK ${ }^{8}$ (1998) para testes de regeneração óssea, ou seja:a) tamanho mínimo do defeito ósseo experimental não deve ser menor que o defeito crítico ósseo, individualizado para a espécie; b) sítio de implantação deve incluir preferencialmente osso cortical e medular; c) defeito deve ser estável; d) risco de fratura deve ser mínimo; e e) modelo animal deve permitir fácil acesso para as análises radiográfica e histológica.

Na literatura pesquisada, existe ainda discordância quanto ao tamanho crítico dos defeitos em calvária de vários animais de laboratório (SCHMITZ; HOLLINGER $^{110}$, 1986). Assim, por exemplo, SANDBERG; DAHLIN; LINDE ${ }^{104}$ (1993), BOSCH; MELSEN; VARGERVIK ${ }^{8}$ (1998) e MARDAS; KOSTOPOULOS; KARRING $^{68}$ (2002) consideraram defeitos críticos para o rato de 5 mm de diâmetro; DUPOIRIEUX et al. ${ }^{37}$ (2001), defeitos de 6 mm; e, DAHLIN; ALBERIUS; LINDE ${ }^{33}$ (1991), defeitos de $8 \mathrm{~mm}$.

A definição do tamanho de uma lesão crítica é fundamental, pois pode comprometer a avaliação pretendida. DUPOIRIEUX et al. ${ }^{37}$ (2001) relataram que três diferentes tipos de membranas não apresentaram diferenças significativas quanto 
ao reparo ósseo, mas em virtude do tamanho do defeito usado, na sua pesquisa, é questionável se isso foi devido à similaridade dos materiais, ou à capacidade de reparação espontânea do tecido. Resultados obtidos, ainda não publicados em nosso laboratório (Briguenti- processo FAPESP 00/05734-2, no prelo), demonstraram que o tamanho do defeito crítico na calvária de cobaias é de 8 mm de diâmetro.

Na presente pesquisa, foi usado defeito de $10 \mathrm{~mm}$ que, por ser maior que o tamanho crítico, torna o reparo da lesão bem mais difícil e o teste mais significativo.

Quanto à localização do defeito, optamos por realizá-la no centro da calvária. Esta nossa opção foi motivada por diversos fatores, tais como: a) inclusão da sutura sagital; b) não ter a interferência da musculatura da orelha; c) disponibilidade de uma área maior de osso; e) possibilidade de criar um defeito de maior diâmetro; e f) grande facilidade para a tomada e a análise radiográfica, manejo e a realização do defeito.

Salientamos que alguns pesquisadores contra-indicam essa localização, pois há o risco de lesar a estrutura anatômica vascular existente abaixo da sutura sagital e de introduzir o tecido conjuntivo proveniente da sutura na avaliação do osso regenerado (BOSCH; MELSEN; VARGERVIK ${ }^{8}$, 1998).

Assim, estes pesquisadores preconizam a realização de defeitos bilaterais em cada animal o que permite uma análise pareada entre o defeito controle e o defeito teste (BOSCH; MELSEN; VARGERVIK ${ }^{8}$, 1998). Mas segundo, DAHLIN; ALBERIUS; LINDE ${ }^{33}$ (1991), KOSTOPOULOS; KARRING ${ }^{61}$ (2000), MARDAS; KOSTOPOULOS; KARRING ${ }^{68}$ (2002), quando defeitos bilaterais são produzidos, eles ficam muito próximos um do outro, podendo a reparação de um defeito interferir no defeito contralateral e mesmo haver a intercomunicação entre os defeitos por 
reabsorção da fina parede divisória e, conseqüentemente, transformar em um único grande defeito, afetando os resultados do experimento.

O tipo de incisão usado na calvária é outro motivo de discussão, já que deve ter as seguintes características: facilitar a visão do leito cirúrgico, ter retalho de fácil manejo, manter o periósteo íntegro, conter o material em experimentação no local e facilitar a sutura. Nos trabalhos de BOSCH; MELSEN; VARGERVIK ${ }^{8}$ (1998); BOHNING et al. $^{7}$ (1999) e DUPOIRIEUX et al. ${ }^{37}$ (2001) utilizaram a incisão em cima da sutura sagital. Salientamos que, nesse tipo de incisão, a coaptação do retalho e do periósteo, dividido no meio pela incisão, fica sobre o defeito, fazendo com que os dois processos de cicatrização, o do tegumento e o do osso, fiquem um sobre o outro, possibilitando interferência entre ambos, podendo desvirtuar o processo de regeneração óssea. No trabalho específico de BOSCH; MELSEN; VARGERVIK ${ }^{8}$ (1998), a sutura ficou em cima do defeito ou tangenciando as bordas do defeito. Segundo comentários de vários pesquisadores, se, nesse caso, a sutura fosse realizada de forma imprudente, poderia ter deslocado o biomaterial, ou se ocorresse o seu rompimento posterior, poderia ter provocado a exposição do material em experimento com instalação de um processo infeccioso e, conseqüentemente, com alteração no resultado final do reparo (JOVANOVIC; SPIEKERMANN; RICHTER $^{52}$, 1992, MURPHY ${ }^{77}, 1995$, NOWZARI; SLOTS ${ }^{80}$, 1995, LEKOVIC et al. $^{62}, 1998$, WANG, CAROLL $\left.{ }^{128}, 2001\right)$. Por causa dessas considerações acima que no presente experimento, adotamos a incisão em meia-lua (SCHLIEPHAKE et al. ${ }^{109}$, 2004), deixando o retalho e o periósteo íntegro sobre o defeito, fazendo com que a sutura ficasse ao lado do defeito a uma distância segura, sem a possibilidade de deslocamento do material em experimentação. 
Os defeitos em todos os animais foram preenchidos com coágulo sangüíneo. É sabido que, para haver crescimento de tecido ósseo, existe a necessidade de preenchimento do defeito com coágulo sangüíneo, permitindo o seu íntimo contato com tecido vivo das paredes do defeito, e conseqüentemente com células osteoprogenitoras e osteoblastos preservadas (MURRAY; HOLDEN; ROACHLAU $^{78}$,1957), o que foi corroborado por observações de MELCHER; DREYER $^{73}$ (1964) em lesões penetrantes no fêmur de ratos protegidos por uma barreira não absorvível.

Utilizamos membranas com formato igual ao do defeito, ou seja, circular, sem ângulos nas bordas. As margens das membranas ficaram a uma distância de 2 a 3 mm além da borda do defeito, como preconizado na utilização de membranas para a osteopromoção (WANG; CAROLL $\left.{ }^{128}, 2001\right)$.

Na revista da literatura, não encontramos trabalhos semelhantes a este que tenham citado a importância do desenho da membrana. Os relatos referem-se apenas que a membrana devia recobrir o defeito e cujas margens deviam estar distantes de 2 a $3 \mathrm{~mm}$ da borda do defeito (HAMMËLRE et al. ${ }^{43}$, 1995; SCHLIEPHAKE et al. ${ }^{109}$, 2004). No caso das membranas, principalmente das não absorvíveis, ângulos retos podem causar dilaceração no retalho e no periósteo, expondo o leito cirúrgico, o material de enxerto ou a membrana ao ambiente externo, favorecendo a colonização bacteriana e iniciando um processo infeccioso e inflamatório na região, prejudicando o processo regenerativo na área.

A análise dos resultados aqui obtidos, no grupo controle, mostrou que não houve o completo fechamento do defeito crítico com $10 \mathrm{~mm}$ de diâmetro por tecido ósseo em nenhuma das cobaias usadas nos 4 períodos analisados . Em todos os casos, 
independente do período, ocorreu a invaginação e proliferação de tecido conjuntivo denso para dentro do defeito, formando-se tecido ósseo somente nas bordas do defeito, como já foi observado, na literatura, por outros (DAHLIN, ALBERIUS; LINDE $^{33}$, 1991, ZAHEDI et al. ${ }^{135}$, 1998, DUPOIRIEUX et al. ${ }^{37}, 2001$, STAL et al. $^{118}$, 2001, MARDAS; KOSTOPOULOS; KARRING ${ }^{68}$, 2002).

Deste modo comprovamos radiográfica e histologicamente, neste trabalho, que o defeito de $10 \mathrm{~mm}$, na calvária de cobaias preenchido somente com coágulo sangüíneo, mesmo após 9 meses, não se regenerou espontaneamente, confirmando-se tratar-se de defeito de tamanho crítico como proposto por SCHMITZ; HOLLINGER ${ }^{110}$ (1986). Áreas radiodensas foram observadas apenas nas bordas ósseas dos defeitos e, em alguns casos, no seu centro, provavelmente devido à presença do espaçador de osso alógeno desmineralizado inativado, que por estar constituído essencialmente de colágeno I, pode ter propriedades osteocondutoras. Relatos semelhantes para outros modelos em animais como calvária de ratos (SCHIMTZ et al., 1990 ${ }^{111}$, DAHLIN, ALBERIUS, LINDE ${ }^{33}$, 1991; DUPOIRIEUX et al. ${ }^{37}$, 2001, MARDAS; KOSTOPOULOS; KARRING ${ }^{68}$, 2002), e mandíbula de ratos (DAHLIN et al. ${ }^{30}, 1988$, ZAHEDI et al. ${ }^{135}$, 1998), macacos (DAHLIN et al. ${ }^{32}$, 1990), coelhos (COLANGELO et al. ${ }^{25}$, 1993) e cachorros (SCHENK et al. ${ }^{107}$, 1994) já haviam sido descritos. Na maioria dos nossos animais, havia uma área radiolúcida, compatível com tecido mole, o que foi confirmado pela nossa análise histológica.

A formação dessa união não óssea constituída de tecido fibroso, segundo SCHMITZ et al ${ }^{111}$. (1990) é por causa da carência de fatores ósseos de crescimento e diferenciação, alterando ou não estimulando a diferenciação de células responsáveis pela neoformação óssea. Por outro lado, OGISO et al. ${ }^{86}$ (1991) relataram que nesses 
casos fibroblastos que, inicialmente invadem o defeito, poderiam sintetizar e secretar algumas substâncias solúveis, capazes de inibir a diferenciação das células ósseas e a osteogênese e que isto estaria marcado pela redução na expressão de fosfatase alcalina no local.

No presente trabalho, um resultado original foi a constatação da angiogênese, a partir da dura-máter no grupo controle.

No grupo experimental, a colocação de uma membrana sobre a dura-máter e outra na abertura externa ou ectodural teve a finalidade de isolar o defeito da invasão por tecido conjuntivo altamente proliferante e não ósseo, a fim de que a osteopromocão ocorresse, a partir das bordas ósseas do defeito por migração de células osteoprogenitoras dos canais nutritivos ósseos, endósteo e medula óssea, mas, isolando também, a capacidade osteogênica da dura-máter e do periósteo (DAHLIN, ALBERIUS; LINDE ${ }^{33}$, 1991).

A colocação de um espaçador reabsorvível, seja ele inativado ou não, entre as membranas está de acordo com ZAHEDI et al. ${ }^{135}$ (1998). Sugeriram que em defeitos maiores que os utilizados em seu experimento (defeito crítico em mandíbulas de ratos) é apropriado à utilização de um mantenedor de espaço para que as membranas à base de colágeno não colabem para dentro do defeito, o que iria prejudicar a regeneração óssea. Outros materiais já haviam sido utilizados para auxiliar na sustentação da membrana e na manutenção do espaço do defeito. Assim, a combinação de osso autógeno e ROG pareceu acelerar a formação de tecido ósseo na região do defeito em calvária de ratos com membranas de e-PTFE (DAHLIN; ALBERIUS; LINDE ${ }^{33}$, 1991). HÜRZELER et al. ${ }^{49}$ (1998), utilizando membrana de colágeno e partículas de hidroxiapatita em defeitos ósseos relacionados a implantes 
em macacos, em comparação com o grupo experimental - membrana sem enxerto, relataram um maior contato osso - implante no grupo com hidroxiapatita, corroborando com resultados de pesquisas semelhantes em humanos e cachorros (ZITZMANN et al. ${ }^{136}$, 1997, HOCKERS et al. ${ }^{46}$, 1999, BUNYARATAVEJ; $\left.\mathrm{WANG}^{14}, 2001\right)$.

Os resultados radiográficos e histológicos obtidos, no nosso grupo experimental, mostraram que a dupla membrana de cortical óssea bovina com espaçador de matriz óssea alogênica promoveu a regeneração óssea em defeito de tamanho crítico em calvária de cobaias, com os defeitos, exibindo fechamento completo com tecido ósseo lamelar após 6-9 meses do tratamento. No entanto, histologicamente o fechamento completo do defeito com osso primário entrelaçado pouco mineralizado, às vezes, não detectável nas radiografias, já havia ocorrido na maioria dos animais com 1 mês pós-cirurgia. Essa osteogênese inicial foi tão intensa e rápida que, em alguns casos, fragmentos de coágulo sangüíneo foram incorporados à matriz óssea neoformada.

DAHLIN; ALBERIUS; LINDE ${ }^{33}$ (1991) estudaram o potencial osteopromotor de dupla membrana de e-PTFE, em defeitos críticos na calvária de ratos, usando partículas de osso autógeno como espaçador e obtiveram resultados próximos aos aqui obtidos. Apesar dos resultados terem sido semelhantes nas duas pesquisas, devemos salientar que eles utilizaram osso autógeno entre as membranas como mantenedor de espaço, que devido a sua capacidade osteogênica, pode ter colaborado para a aceleração do processo de formação óssea, enquanto no nosso experimento utilizamos apenas as membranas de colágeno e um espaçador inativado. 
Nossos resultados mostraram, em alguns casos, nos vários períodos analisados, a formação de tecido ósseo nas superfícies da membrana colocada em posição epidural, provocando a sua incorporação ao novo tecido ósseo formado e aumentando a espessura do tecido ósseo na região, principalmente junto às bordas do defeito. Isto ocorreu com menor intensidade na membrana colocada na região ectodural. Este fato indicou que a membrana testada, além da alta biocompatibilidade com o tecido ósseo, apresentou capacidade ostecondutora, sugerindo que possa ser uma candidata a ser utilizado como suporte para células ósseas em técnicas de engenharia tecidual.

Em alguns dos nossos casos, no período de 1 e 3 meses pós-cirurgia, existia medula óssea altamente vascularizada junto ao osso compacto. No entanto, a espessura do tecido ósseo neoformado era menor do que a do tecido ósseo original, encontrado na calvária, e já havia uma estrutura semelhante à sutura sagital localizada na parte central inferior. Esses resultados foram semelhantes aos observados por outros pesquisadores, testando outras membranas em calvária de ratos e coelhos (DUPOIRIEUX et al. $^{37}$, 2001, STAL et al. ${ }^{118}$, 2001, MARDAS; KOSTOPOULOS; KARRING ${ }^{68}$, 2002).

No período de 6 e 9 meses, o novo osso consistia duma combinação de osso compacto e medular e os pequenos fragmentos da membrana pareciam estar ainda incorporados ao osso em remodelação. A díploe apresentava, na sua porção interna, formação trabecular com medula óssea e, em alguns casos, aos 9 meses, o tecido formado se assemelhava quantitativa e morfologicamente ao tecido ósseo original da calvária, como também observaram DAHLIN; ALBERIUS; LINDE ${ }^{33}$ (1991). Em todos os nossos casos, a formação óssea ocorreu por ossificação intramembranosa, 
contudo SANDBERG; DAHLIN; LINDE ${ }^{104}$ em 1993 observaram em sua pesquisa que o processo de ossificação foi do tipo endocondral, segundo eles possivelmente devido à baixa oxigenação em função da dificuldade na difusão gasosa através das membranas utilizadas no seu experimento.

No nosso estudo, observamos histologicamente que a maturação do tecido ósseo primário entrelaçado que preencheu inicialmente o defeito, começou aos 3 meses e perdurou até os 6 meses, quando o tecido ósseo lamelar estruturado em duas corticais e uma medular já eram observados na maioria dos casos. No entanto, ZAHEDI et al. ${ }^{135}$ (1998) não observaram diferenças entre esses períodos, sugerindo uma mais rápida maturação em seu estudo. A possível causa desta diferença de resultados pode estar relacionada ao modelo experimental usado por esses pesquisadores, eles utilizaram o ramo da mandíbula de ratos em seu estudo. Salientamos ainda que a membrana de colágeno utilizada em seu estudo já havia sido totalmente reabsorvida aos 3 meses, enquanto em nosso trabalho, nesse período, ele ainda estava presente em ambas as posições.

Um outro fator, que devemos salientar, é que a despeito da utilização de um espaçador colagênico alguns espécimes apresentaram colapso da membrana para dentro do defeito, provavelmente devido a uma mais rápida reabsorção do anteparo e nesses casos, prejudicando a maior formação óssea na região. O mesmo fato já havia sido observado por LINDE et al. ${ }^{63}$ (1993) utilizando membranas de e-PTFE. Salientamos que este colapso pode ser evitado com o uso de membranas rígidas (STAL et al. ${ }^{118}$, 2001), ou pela colocação de biomaterial de preenchimento no defeito (DAHLIN; ALBERIUS; LINDE ${ }^{33}$, 1991), permitindo com isso o crescimento centrípeto ininterrupto de osso, a partir das margens do defeito. 
A variação na espessura da membrana usada em cada animal também pode ter influenciado na variabilidade da resposta dentro de cada grupo, uma vez que houve maior formação óssea nos casos onde as membranas permaneceram por mais tempo, enquanto nos animais que apresentaram uma mais rápida reabsorção das membranas, a quantidade de tecido ósseo neoformado foi menor. Esses achados sugerem que o aumento na espessura da membrana, durante a sua produção, seria desejável para a obtenção de resultados melhores, porém salientamos que esse aumento teria um limite, pois poderia causar dificuldades no seu manejo devido à diminuição da sua maleabilidade e adaptabilidade ao sítio receptor. Nesse sentido, lembramos que FUGAZZOTTO ${ }^{38}$ (1995) relatou dificuldades quando utilizou lâminas de osso desmineralizado humana com maior espessura em casos de ROG relacionados a implantes osseointegrados.

A situação oposta também poderia comprometer a reparação, ou seja, uma menor espessura da membrana poderia, durante o ato cirúrgico, promover o aparecimento de dobras, comprometendo o processo de ROG dependendo de sua localização. Em nosso estudo, a presença do espaçador minimizou a formação de dobras, mas, quando presentes interferiam com o reparo. SCOTT et al. ${ }^{112}$ (1997), estudando lesões de bifurcação classe II mandibulares em humanos, relataram que a presença de dobras na membrana de colágeno comprometeu os seus resultados finais por causa da menor formação óssea nessas regiões.

Por outro lado, KASSOLIS e BOWERS ${ }^{57}$, em 1999, relataram que o uso de lâminas de matriz óssea de cortical humana desmineralizada de menor espessura causou menor edema e dor, do que lâminas mais espessas em casos clínicos de ganho 
ósseo em perdas horizontais. As espessuras das lâminas variavam de 100 - $500 \mu \mathrm{m}$ e resultaram em ganho médio de 3mm de tecido ósseo em 7 pacientes.

A análise morfométrica em imagens radiográficas mostrou um paralelismo na formação óssea entre o grupo controle e experimental até o período de 3 meses pós-cirurgia. Após este tempo, enquanto a deposição de tecido ósseo diminuiu drasticamente no grupo controle, com estabilização do defeito ósseo; no grupo experimental a neoformação óssea continuou seguindo o mesmo padrão anterior, diminuindo gradativamente o tamanho do defeito até o seu fechamento completo na maioria dos casos.

Ao final de 9 meses, o ganho ósseo médio em relação ao defeito original no grupo experimental foi de 96, 2 \%. Está relatado, na literatura, que a utilização de membranas não absorvíveis para aumentar a quantidade de tecido ósseo na calvária de ratos resultou em ganho de $80 \%$ do volume da cúpula feita com a membrana de ePTFE depois de 9 a 16 semanas (LINDE et al. ${ }^{63}$, 1993). ITO; NANBA; MURAI ${ }^{50}$ (1998) comparando membranas não absorvíveis (e-PTFE) com absorvíveis (ácido polilático) em calvária de coelhos, no período de 6 meses, obtiveram uma recuperação da ordem de 89,0\% com membrana de e-PTFE e de 54,7\% com membrana de ácido polilático. Segundo estes autores, esta diferença foi possível graças à capacidade da membrana de e-PTFE manter a forma desejada, sugerindo que a membrana de e-PTFE é a mais indicada para o aumento vertical de tecido ósseo, o que foi referendado por outros autores (KASSOLIS; BOWERS ${ }^{57}$, 1999; YAMAOKA et al. ${ }^{133}$, 1996).

A análise estatística dos dados morfométricos mostrou, no grupo controle um aumento na área do defeito, após período de 6 meses, sugerindo que parte do 
tecido ósseo neoformado anteriormente era reabsorvido durante a remodelação com aumento no tamanho do defeito. Outros trabalhos (BRIGHENTI; ASSAOKA, no prelo) na mesma linha foram desenvolvidos em nosso laboratório e também detectaram este aumento no defeito após períodos mais longos.

Em nosso estudo, a membrana de colágeno derivada do osso cortical bovino foi reabsorvida mais lentamente que o relatado em outros estudos com membrana de colágeno, como o de OWENS e YUKNA ${ }^{87}$ (2001) que não identificaram nem fragmentos de sua membrana, após 4 meses da implantação, no palato de cães. Esse maior tempo de manutenção da membrana do osso bovino é provavelmente devido às ligações cruzadas naturalmente presentes no material, sugerindo não ser necessária nesse tipo de membrana, a inclusão artificial de novas ligações cruzadas para aumentar a sua resistência à reabsorção.

No nosso caso, fragmentos das membranas, principalmente da interna, foram observados mesmo depois de 9 meses. Membranas com certa integridade estrutural foram detectadas nos vários animais com 3 meses de tratamento. Após decorrido 1 mês de tratamento, a maioria dos animais exibia o defeito quase que totalmente preenchido por osso primário entrelaçado, e as evidências sugerem que a manutenção de sua integridade por 1-3 meses é suficiente para que as membranas exerçam a sua atividade osteopromotora, protegendo o coágulo, criando um ambiente molecular e celular e favorecendo a proliferação e migração de células e vasos sangüíneos do interior dos ossos da borda do defeito e a diferenciação e maturação dos osteoblastos diretamente do tecido de granulação formado e a deposição extremamente rápida de matriz de osso imaturo ou primário em todo espaço do defeito. 
Como a membrana, aqui testada, é de origem bovina, é importante ressaltar também que o risco de transmissão da doença da "vaca louca" (doença de Creutzfeldt-Jakob) é mínimo nesse caso, em primeiro lugar em função das peculiaridades na criação do rebanho brasileiro, feita em pasto aberto e sem a utilização de ração constituída de tecidos de animais e pelo controle contra a importação de animais contaminados e em segundo lugar pelo processamento químico com ácidos e álcalis fortes a que é submetido o osso bovino durante a fase produtiva minimizaria sobremaneira qualquer potencial de risco da transmissão dessa doença (WEBER et al. ${ }^{129}$, 1993; MARTINEZ-LAGE et al. ${ }^{70}, 1994$ ).

Um outro fato importante foi a ausência de resposta inflamatória à implantação das membranas em todos os períodos analisados, sugerindo uma biocompatibilidade completa do material com o organismo das cobaias.

Assim, em vista dos resultados aqui obtidos, a membrana de cortical óssea bovina comprovou ser altamente biocompatível, exibiu alta capacidade osteopromotora, permanecendo em função, por tempo suficiente para a regeneração óssea e mostrou ter propriedades osteocondutoras, permitindo a neoformação óssea em suas superfícies.

Um fator importante a discutir de uma membrana ideal é a permeabilidade. A permeabilidade às moléculas, mas não às células é um dos requisitos de uma membrana ideal. No nosso estudo, na análise microestrutural, a membrana de colágeno mostrou pequenas porosidades $(9,98 \mu \mathrm{m})$ em grande quantidade correspondentes às lacunas dos osteócitos e seus canalículos ósseos, além de pequena quantidade de grandes poros referentes aos canais de Haver e Volkmann, apresentando diâmetro médio de $61,98 \mu \mathrm{m}$, esses últimos muito semelhantes aos 
observados por SCHENK ${ }^{106}$ (1994) em membranas de e-PTFE. Apesar do diâmetro dos poros maiores, teoricamente possibilitarem a passagem de células e pequenos vasos, as nossas observações não sugerem essa ocorrência. Este tema ainda é controverso, a presença de porosidades pequenas parece ser importante para a passagem de moléculas como fatores de crescimento que poderiam ser produzidas pelos tecidos vizinhos, em relação aos poros maiores, sugere-se que, os fibroblastos e outras células presentes, invaginam para o seu interior colonizando-os sem que ocorra a passagem destas células para dentro do defeito. No nosso estudo, observamos este fenômeno com células mononucleadas, invaginando para dentro desses espaços, preenchendo-os e provavelmente atuando na reabsorção posterior da própria membrana. A união dos fibroblastos à membrana, segundo SCHENK ${ }^{106}$ (1994), causa uma maior interação de todo o processo cicatricial fazendo com que haja um contato direto da superfície da membrana com o tecido, dentro e fora do defeito, permitindo uma interação intertecidual através da membrana via fatores de crescimento desta membrana com estes tecidos confirmando a biocompatibilidade da membrana de colágeno utilizada no nosso experimento. 


\section{CONCLUSÃO}

A análise dos resultados apresentados neste trabalho, dentro das limitações inerentes ao modelo experimental, permitiu concluir que:

1) a lesão de tamanho crítico na calvária de cobaia é um modelo adequado para o estudo de biomateriais para enxerto ósseo;

2) a membrana derivada da cortical óssea bovina desmineralizada é biocompatível e biodegradável mostrada através da análise microestrutural a presença de poros compatíveis com os canais de Havers e Volkman;

3) a análise estatística e morfométrica das imagens radiográficas em conjunto com a análise histológica permitiu acompanhar o processo de reparo ósseo durante os períodos analisados e concluir que houve um fechamento médio de $96,2 \%$ da lesão com novo osso no grupo experimental contra 45,4\% do grupo controle ao final de 9 meses;

4) a membrana favorece o reparo ósseo por permanecer íntegra por tempo suficiente para a reorganização do coágulo e a osteopromoção com a formação de novo osso a partir das bordas do defeito;

5) a membrana exibiu propriedades de osteocondução, favorecendo à neoformação óssea nas suas superfícies. 
ANEXO 1

\begin{tabular}{|c|c|c|c|c|c|}
\hline INDIVÍDUO & GRUPO & TEMPO & PIXEL $^{2}$ (ARLUC) & ARLUC $\left(\mathrm{MM}^{2}\right)$ & AROP $\left(\mathrm{MM}^{2}\right)$ \\
\hline 1 & padrão & 0 hora & $29748(\mathrm{Ai})$ & 66,474 & 0 \\
\hline 2 & padrão & 0 hora & 29001(Ai) & 66,185 & 0 \\
\hline 3 & controle & 1 mês & 24599 & 55,547 & 10,783 \\
\hline 4 & controle & 1 mês & 22883 & 51,672 & 14,658 \\
\hline 5 & controle & 1 mês & 21148 & 47,754 & 18,576 \\
\hline 6 & controle & 1 mês & 19413 & 43,836 & 22,494 \\
\hline 7 & controle & 1 mês & 27500 & 62,097 & 4,233 \\
\hline 8 & controle & 3 meses & 9188 & 20,747 & 45,583 \\
\hline 9 & controle & 3 meses & 18699 & 42,224 & 24,106 \\
\hline 10 & controle & 3 meses & 22987 & 51,907 & 14,423 \\
\hline 11 & controle & 3 meses & 20914 & 47,226 & 19,104 \\
\hline 12 & controle & 3 meses & 18336 & 41,404 & 24,926 \\
\hline 13 & controle & 6 meses & 18526 & 41,833 & 24,497 \\
\hline 14 & controle & 6 meses & 10399 & 23,482 & 42,848 \\
\hline 15 & controle & 6 meses & 3680 & 8,31 & 58,020 \\
\hline 16 & controle & 6 meses & 18332 & 41,395 & 24,935 \\
\hline 17 & controle & 6 meses & 14495 & 32,731 & 33,599 \\
\hline 18 & controle & 9 meses & 18814 & 42,484 & 23,846 \\
\hline 19 & controle & 9 meses & 11887 & 26,842 & 39,488 \\
\hline 20 & controle & 9 meses & 16442 & 37,127 & 29,203 \\
\hline 21 & controle & 9 meses & 19328 & 43,644 & 22,686 \\
\hline 22 & controle & 9 meses & 13594 & 30,696 & 35,634 \\
\hline 23 & Experimental & 1 mês & 28119 & 63,495 & 2,835 \\
\hline 24 & Experimental & 1 mês & 18052 & 40,763 & 25,567 \\
\hline 25 & Experimental & 1 mês & 24117 & 54,458 & 55,942 \\
\hline 26 & Experimental & 1 mês & 8909 & 20,117 & 46,213 \\
\hline 27 & Experimental & 1 mês & 21150 & 47,758 & 18,572 \\
\hline 28 & Experimental & 3 meses & 18997 & 42,897 & 23,433 \\
\hline 29 & Experimental & 3 meses & 8354 & 18,864 & 47,466 \\
\hline 30 & Experimental & 3 meses & 14856 & 33,546 & 32,784 \\
\hline 31 & Experimental & 3 meses & 6861 & 15,493 & 50,837 \\
\hline 32 & Experimental & 3 meses & 9941 & 22,448 & 43,882 \\
\hline 33 & Experimental & 6 meses & 2281 & 5,151 & 61,179 \\
\hline 34 & Experimental & 6 meses & 5674 & 12,812 & 53,518 \\
\hline 35 & Experimental & 6 meses & 9028 & 20,386 & 45,944 \\
\hline 36 & Experimental & 6 meses & 9651 & 21,793 & 44,537 \\
\hline 37 & Experimental & 6 meses & 0 & 0 & 66,330 \\
\hline 48 & Experimental & 9 meses & 1822 & 4,114 & 62,216 \\
\hline 39 & Experimental & 9 meses & 986 & 2,226 & 64,104 \\
\hline 40 & Experimental & 9 meses & 1756 & 3,965 & 62,365 \\
\hline 41 & Experimental & 9 meses & 0 & 0 & 66,330 \\
\hline 42 & Experimental & 9 meses & 911 & 2,057 & 64,273 \\
\hline
\end{tabular}




\section{Referências Bibliográficas}




\section{REFERÊNCIAS BIBLIOGRAFICAS*}

1 ASHLEY, F.L.; STONE, R.S. et al. Experimental and clinical studies on the application of monomolecular cellulose filter tubes to create artificial tendon sheaths in digits. Plast Reconstr Surg, v. 23, p. 526-34, 1959.

BECKER, W. et al. New attachment after treatment with root isolation procedures: report for treated Class III and Class II furcations and vertical osseous defects. Int J Periodontics Restorative Dent, v.8, n.3, p.8-23, 1988.

BECKER, W. et al. Bone formation at dehisced dental implant sites treated with implant augmentation material: a pilot study in dogs. Int J Periodontics Restorative Dent, v.10, n.2, p.92-101, 1990.

BECKER, W., BECKER, B.E. Treatment of mandibular 3-wall intrabony defects by flap debridement and expanded polytetrafluoroethylene barrier membranes. Long-term evaluation of 32 treated patients. J Periodontol, v.64, n.11 Suppl, p.1138-44, Nov. 1993.

5 BENQUE, E. et al. Guided tissue regeneration using a collagen membrane in chronic adult and rapidly progressive periodontitis patients in the treatment of 3-wall intrabony defects. J Clin Periodontol, v.24, n.8, p.544-9, Aug. 1997.

BENQUE, E.et al. Tomodensitometric and histologic evaluation of the combined use of a collagen membrane and a hydroxyapatite spacer for guided bone regeneration: a clinical report. Int J Oral Maxillofac Implants, v.14, n.2, p.258-64, Mar./Apr. 1999.

BOHNING, B.P.; DAVENPORT, W.D.; JEANSONNE, B.G. The effect of guided tissue regeneration on the healing of osseous defects in rat calvaria. J Endod, v.25, n.2, p.81-4, Feb. 1999.

8 BOSCH, C.; MELSEN, B.; VARGERVIK, K. Importance of the critical-size bone defect in testing bone-regenerating materials. J Craniofac Surg, v.9, n.4, p. 310-6, July. 1998.

BOWERS, G.M. et al. Histologic evaluation of new attachment apparatus formation in humans. Part I,II and III. J Periodontol, v.60, n.12, p.66493, Dec. 1989.

\footnotetext{
* Normas recomendadas para uso no âmbito da Universidade de São Paulo, com base no documento "Referências Bibliográficas: exemplos", emanados do Conselho Supervisor do Sistema Integrado de Bibliotecas da USP, em reunião de 20 de setembro de 1990.
} 
10

BROWN, J.C.; TIMPL, R. The collagen superfamily. Int Arch Allergy Immunol, v.107, n.4, p. 484-90, Aug. 1995 apud TATAKIS, D.N.; PROMSUDTHI, A.; WIKWSJÖ, U.M.E. Devices for periodontal regeneration. Periodontol 2000, v.19, p. 59-73, 1999.

BRUNEL, G. et al. Regeneration of rat calvarial defects using a bioabsorbable membrane technique: influence of collagen cross-linking. $\mathbf{J}$ Periodontol, v.67, n.12, p.1342-8, Dec. 1996.

BRUNEL, G. et al. Bioabsorbable materials for guided bone regeneration prior to implant placement and 7-year follow-up: report of 14 cases. J Periodontol, v.72, n.2, p.257-64, Feb. 2001.

BUNYARATAVEJ, P.; WANG, H.L. Collagen membranes: a review. J Periodontol, 2001 Feb;72(2):215-29.

BUSER, D. et al. Localized ridge augmentation using guided bone regeneration. 1. Surgical procedure in the maxilla. Int $\mathbf{J}$ Periodontics Restorative Dent, v.13, n.1, p.29-45, 1993.

BUSER, D.; DAHLIN, C.; SCHENK, R.K. Guided bone regeneration in implant dentistry. Chicago, Quintessence books, 1994.

BUSER, D. et al. Localized ridge augmentation with autografts and barrier membranes. Periodontol, v.19, p.151-63, Feb. 1999.

CAFFESSE, R.G. et al. Cell proliferation after flap surgery, root conditioning and fibronectin application. J Periodontol, v.58, n.10, p.661-6, Oct.1987.

19 CALLAN, D.P. Guided tissue regeneration without a stage 2 surgical procedure. Int J Periodontics Restorative Dent, v.13, n.2, p.172-9, 1993.

20 CAMPBELL, J.B.; BASSET, C.A.L. The surgical aplication of monomolecular filtres (Milipore) to bridge gaps in peripheral nerves and to prevent neuroma formation. Surg Forum, v.7, p.570-4, 1956.

21 CATON, J.; NYMAN, S. Histometric evaluation of periodontal surgery. I. The modified Widman flap procedure. J Clin Periodontol, v.7, n.3, p.212-23, June. 1980.

CATON, J.; NYMAN, S.; ZANDER, H. Histometric evaluation of periodontal surgery. II. Connective tissue attachment levels after four regenerative procedures. J Clin Periodontol, v.7,n.3, p.224-31, June. 1980. 
23 CHANG, C.; HOUCK, J.C. Demonstration of the chemotactic properties of collagen. Proc Soc Exp Biol Med, v.134, n.1, p.22-6, May 1970 apud WANG, H-L.; CAROLL, W.J. Guided bone regeneration using bone grafts and collagen membranes. Quintessence Int, v.32, n.7, p.504-15, 2001.

24 CHVAPIL, M. The fate of natural tissue prostheses. In: WILLIAMS, D.F. ed. Fundamental aspects of biocompatibility. Boca Raton: CRC Press, p.87-104, 1981 apud WANG, H-L.; CAROLL, W.J. Guided bone regeneration using bone grafts and collagen membranes. Quintessence Int, v.32, n.7, p.504-15, 2001.

COLANGELO, P. et al. Bone regeneration guided by resorbable collagen membranes in rabbits: a pilot study. Implant Dent, v.2, n.2, p.101-5, Summer 1993.

COOPERMAN, L.; MICHAELI, D. The immunogenicity of injectable collagen. I. A 1-year prospective study. J Am Acad Dermatol v.10, n.4, p.638-46, Apr. 1984 apud WANG, H-L.; CAROLL, W.J. Guided bone regeneration using bone grafts and collagen membranes. Quintessence Int, v.32, n.7, p.504-15, 2001.

CORTELLINI, P.; CLAUSER, C.; PRATO, G.P. Histologic assessment of new attachment following the treatment of a human buccal recession by means of a guided tissue regeneration procedure. J Periodontol, v.64, n.5, p.387-91, May 1993.

CORTELLINI, P.; TONETTI, M.S. Focus on intrabony defects: guided tissue regeneration. Periodontol 2000, v. 22, p.104-32, Feb 2000.

CRIGGER, M. et al. Repair following treatment of circumferential periodontal defects in dogs with collagen and expanded polytetrafluoroethylene barrier membranes. J Periodontol, v.67, n.4, p.403-13, Apr. 1996.

DAHLIN, C. et al. Healing of bone defects by guided tissue regeneration. Plast Reconstr Surg, v.24, n.1, p.672-6, May 1988.

31 DAHLIN, C. et al. Generation of new bone around titanium implants using a membrane technique: an experimental study in rabbits. Int $\mathbf{J}$ Oral Maxillofac Implants, v.4, n.1, p. 19-25, Spring 1989.

DAHLIN, C. et al. Healing of maxillary and mandibular bone defects using a membrane technique. An experimental study in monkeys. Scand J Plast Reconstr Surg Hand Surg v.24, n.1, p.13-9, 1990.

DAHLIN, C.; ALBERIUS, P.; LINDE, A. Osteopromotion for cranioplasty. An experimental study in rats using a membrane technique. J Neurosurg, v.74, n.3, p.487-91, Mar. 1991. 
DAHLIN, C.; ANDERSSON, L.; LINDE, A. Bone augmentation at fenestrated implants by an osteopromotive membrane technique. A controlled clinical study. Clin Oral Implants Res, v.2, n.4, p.159-65, Oct./Dec. 1991.

35 DAHLIN, C.; LEKHOLM, U.; LINDE, A. Membrane-induced bone augmentation at titanium implants. A report on ten fixtures followed from 1 to 3 years after loading. Int J Periodontics Restorative Dent, v.11, n.4, p.273-81, 1991.

36 DONGIEUX, J.W. et al. The effect of different membranes on onlay bone graft success in the dog mandible. Oral Surg Oral Med Oral Pathol Oral Radiol Endod, v.86, n.2, p.145-51, Aug. 1998.

DUPOIRIEUX, L., POURQUIER, D., PICOT, M.C., NEVES, M. Comparative study of three different membranes for guided bone regeneration of rat cranial defects. Int J Oral Maxillofac Surg, v.30, n.1, p.58-62, Feb. 2001.

FUGAZZOTTO, P.A. The use of demineralized laminar bone sheets in guided bone regeneration procedures: report of three cases. Int $\mathbf{j}$ Oral Maxilofac Implants, v.11, p.239-244, 1995.

GARRETT, S.; MARTIN, M.; EGELBERG, J. Treatment of periodontal furcation defects. Coronally positioned flaps versus dura mater membranes in class II defects. J Clin Periodontol, v.17, n.3, p.179-185, Mar. 1990

GOTTLOW, J. et al. New attachment formation in the human periodontium by guided tissue regeneration. Case reports. J Clin Periodontol, v.13, n.6, p.604-16, July. 1986.

41 GRAY, J.L.; HANCOCK, E.B. Guided tissue regeneration. Nonabsorbable barriers. Dent Clin North Am, v.42, n.3, p.523-41, July. 1998.

42 GRINNELL, F. Cell-collagen interactions: overview. Methods Enzymol, 1982;82 Pt A:499-503 apud WANG, H-L.; CAROLL, W.J. Guided bone regeneration using bone grafts and collagen membranes. Quintessence Int, v.32, n.7, p.504-15, 2001.

HAMMËRLE, C.H., SCHMID, J., LANG, N.P., OLAH, A.J. Temporal dynamics of healing in rabbit cranial defects using guided bone regeneration. J Oral Maxillofac Surg, v.53, n.2, p.167-74, Fev. 1995

HEATH, J.K. et al. Bacterial antigens induce collagenase and prostaglandin E2 synthesis in human gingival fibroblasts through a primary effect on circulating mononuclear cells. Infect Immun, v.55, n.9, p.2148-54, Sept. 1987. 
HERCULIANI, P.P.; CESTARI, T.M.; TAGA, E.M.; TAGA, R. Tratamento de defeito ósseo perene em calvária de cobaia com membrana de cortical óssea bovina liofilizada associada ou não a enxerto ósseo bovino desmineralizado. Rev Bras Implant, v.1, n.1, p.7-14, 2000.

HOCKERS, T. et al. The combined use of bioresorbable membranes and xenografts or autografts in the treatment of bone defects around implants. A study in beagle dogs. Clin Oral Implants Res, v.10, n.6, p.487-98, Dec. 1999.

HOUAISS, A. Dicionário Houaiss da língua portuguesa. Rio de Janeiro; Editora Objetiva, 2001.

HURLEY, L.A. et al. The role of soft tissue in osteogenesis. An experimental study of canine spinal fusions. J bone Joint Surg, v. 41A, p.1243-54, 1959.

HÜRZELER, M.B. et al. Evaluation of a new bioresorbable barrier to facilitate guided bone regeneration around exposed implant threads. An experimental study in the monkey. Int J Oral Maxillofac Surg, v.27, n.4, p.315-20, Aug. 1998.

50 ITO, K.; NANBA, K.; MURAI, S. Effects of bioabsorbable and nonresorbable barrier membranes on bone augmentation in rabbit calvaria. $\mathbf{J}$ Periodontol, v.69, n.11, p.1229-37, Nov. 1998.

51 JOHNS, L.P. et al. Immunogenicity of a bovine collagen membrane in guided tissue regeneration [ abstract 1538]. J Dent Res, v.71, p.298, 1992. 71:298 apud WANG, H-L.; CAROLL, W.J. Guided bone regeneration using bone grafts and collagen membranes. Quintessence Int, v.32, n.7, p.504-15, 2001.

52 JOVANOVIC, S.A.; SPIEKERMANN, H.; RICHTER, E.J. Bone regeneration around titanium dental implants in dehisced defect sites: a clinical study. Int J Oral Maxillofac Implants, v.7, n.2, p.233-45, Summer 1992.

53 KAHNBERG, K.E. Restoration of mandibular jaw defects in the rabbit by subperiosteally implanted Teflon mantle leaf. Int J Oral Surg, v.8, n.6,p.449-56, Dec.1979.

54 KALDAHL, W.B. et al. Long-term evaluation of periodontal therapy: I. Response to 4 therapeutic modalities. J Periodontol, v. 67, n.2.p.93-102, Feb. 1996.

55 KARRING, T.; NYMAN, S.; LINDHE, J. Healing following implantation of periodontitis affected roots into bone tissue. J Clin Periodontol, v.7, n.5, p.96-105, Oct. 1980. 
56 KARRING, T.; CORTELLINI, P. Regenerative therapy: furcation defects. Periodontol 2000, v.19, p.115-37, Feb. 1999.

57 KASSOLIS, J.D.; BOWERS, G.M. Supracrestal bone regeneration: a pilot study. Int. J. Periodontics Restorative Dent, v.19, n.2, p.131-9, Apr, 1999. Erratum: Int. J. Periodontics Restorative Dent, v.19, n.4, p.314, aug, 1999.

58 KLEINMAN, H.K.; KLEBE, R.J.; MARTIN, G.R. Role of collagenous matrices in the adhesion and growth of cells. J Cell Biol, 1981 Mar;88(3):473-85 apud WANG, H-L.; CAROLL, W.J. Guided bone regeneration using bone grafts and collagen membranes. Quintessence Int, v.32, n.7, p.504-15, 2001.

59 KNOX, R.; CAUDILL, R.; MEFFERT, R. Histologic evaluation of dental endosseous implants placed in surgically created extraction defects. Int $\mathbf{J}$ Periodontics Restorative Dent, v.11, n.5, p.364-75, 1991.

60 KODAMA, T. et al. The effect of various concentrations of collagen barrier on periodontal wound healing. J Periodontol, v.60, n.4, p.205-10, Apr. 1989.

61 KOSTOPOULOS, L.; KARRING, T. Regeneration of the sagittal suture by GTR and its impact on growth of the cranial vault. J Craniofac Surg, v.11,n.6,p.553-61, Nov. 2000. Comentários em: J Craniofac Surg, v.12, n.2, p.197-9, Mar. 2001.

62 LEKOVIC, V. et al. Preservation of alveolar bone in extraction sockets using bioabsorbable membranes. J Periodontol, v.69, n.9, p.1044-9, Set. 1998.

63 LINDE, A. et al. Creation of new bone by an osteopromotive membrane technique: an experimental study in rats. J Oral Maxillofac Surg, v.51, n.8, p.892-7, Aug. 1993.

64 LINGHORNE, W. J. The sequences of events in osteogenesis as studied in polyethylene tubes. Ann NY Acad Sci, p.445, 1960.

65 LOCCI, P. et al. Phenotype expression of gingival fibroblasts cultures on membranes used in guided tissue regeneration. J Periodontol, v.68, n.9, p.857-63, 1997 apud WANG, H-L.; CAROLL, W.J. Guided bone regeneration using bone grafts and collagen membranes. Quintessence Int, v.32, n.7, p.504-15, 2001.

MACHTEI, E.E.; SCHALLHORN, R.G. Successful regeneration of mandibular Class II furcation defects: an evidence-based treatment approach. Int J Periodontics Restorative Dent, v.15, n.2, p.146-67, Apr. 1995. 
MACHTEI, E.E. et al. Long-term stability of Class II furcation defects treated with barrier membranes. J Periodontol, v.67, n.5, p.523-7, May 1996.

MARDAS, N.; KOSTOPOULOS, L.; KARRING, T. Bone and suture regeneration in calvarial defects by e-PTFE-membranes and demineralized bone matrix and the impact on calvarial growth: an experimental study in the rat. J Craniofac Surg, v.13, n.3, p.453-62, May 2002 ; discussão p.462-4.

MARINUCCI, L. et al. In vitro comparison of bioabsorbable and nonresorbable membranes in bone regeneration. J Periodontol, v.72, n.6, p.753-9, 2001.

MARTINEZ-LAGE, J.F. et al. Accidental transmission of Creutzfeldt Jakob disease by dural cadaveric grafts. J neurol Neurosurg Psychiatry, v.57, p.1091-4, 1994.

71 MAYRAND, D.; GRENIER, D. Detection of collagenase activity in oral bacteria. Can J Microbiol, v.31, n.2, p.134-8, Feb. 1985.

72 McGINNIS, M. et al. Comparison of resorbable and nonresorbable guided bone regeneration materials: a preliminary study. Int J Oral Maxillofac Implants, v.13, n.1, p.30-5, Jan./Feb. 1998.

73 MELCHER, A.H.; DREYER, C.J. Protection of the blood clot in healing circumscribed bone defects. J Bone Joint Surg, v. 43, p.827, 1964.

MELCHER, A.H. On the repair potential of the periodontal tissues. J Periodontol,. v.47, n. 5, p.256-60, May 1976.

MILLER, N. et al. Resorption rates of 2 commercially available bioresorbable membranes. A histomorphometric study in a rabbit model. J Clin Periodontol, v.23, n.12, p.1051-9, Dec. 1996.

76 MINABE, M. et al. Different cross-linked types of collagen implanted in rat palatal gingiva. J Periodontol, v.60, n.1, p.35-43, Jan. 1989.

77 MURPHY, K.G. Incidence of characterization and effect of postoperative surgical complications using Gore-Tex periodontal material. Part I. Inicdence and character of complications. Int $\mathbf{J}$ Periodontics Restorative Dent, v.15, p.363-75, 1995.

MURRAY, G.; HOLDEN, R.; RACHLAU, W. Experimental and clinical study of new growth of bone in a cavity. Am J Surg, v.93, p.385,1957.

National Institute of Neurological Disorders and Stroke. Disponível na internet.http://www.ninds.nih.gov/health_and_medical/pubs/creutzfeldtjakob_disease_fact_sheet.htm . 15 Mar. 2002. 
80

NOWZARI, H.; SLOTS, J. Microbiologic and clinical study of expanded polytetrafluorethylene membranes for guided bone regeneration around implants. Int J Periodontics Restorative Dent, v.10, p.67-73, 1995.

81 NUMABE, Y. et al. Epithelial cell kinetics with atelocollagen membranes: a study in rats. J Periodontol, v.64, n.8, p.706-12, Aug. 1993.

NYMAN, S. et al. Healing following implantation of periodontitis affected roots into gingival connective tissue. J Clin Periodontol, v.7, n.5, p.394401, Oct.1980.

83 NYMAN, S. et al. New attachment following surgical treatment of human periodontal disease. J Clin Periodontol, v.9, n.4, p.290-6, July. 1982

84 NYMAN, S. et al. The regenerative potential of the periodontal ligament. An experimental study in the monkey. J Clin Periodontol., v.9, n.3, p.25765, May 1982.

85 NYMAN, S. Bone regeneration using the principle of guided tissue regeneration. J Clin Periodontol, v.18, n.6, p.494-8, July 1991.

86 OGISO, B. et al. Fibroblasts inhibit mineralized bone nodule,formation by rat bone marrow stromal cells in vitro. J Cell Physiol, v.146, n.3, p.44250, Mar. 1991.

87 OWENS, K.W.; YUKNA, R.A. Collagen membrane resorption in dogs:a comparative study. Implant Dent, v.10, n.1, p.49-58, 2001.

88 PACHENCE, J.M. Collagen-based devices for soft tissue repair. J Biomed Mater Res, v.33, n.1, Spring 1996.

89 PASQUALE, L.N.; INFANTE, U. Gramática da Língua Portuguesa. São Paulo: Editora Scipione, 2004.

90 PARODI, R.; SANTARELLI, G.; CARUSI, G. Application of slowresorbing collagen membrane to periodontal and peri-implant guided tissue regeneration. Int $\mathbf{J}$ Periodontics Restorative Dent, v.16, n.2, p.174-85, Apr. 1996.

91 PARODI, R. et al. Implant placement in large edentulous ridges expanded by GBR using a bioresorbable collagen membrane. Int J Periodontics Restorative Dent, v.18, n.3, p.266-75, June. 1998

92 PAUL, B.F. et al. Use of a collagen barrier to enhance healing in human periodontal furcation defects. Int J Periodontics Restorative Dent, v.12, n.2, p.123-31, 1992.

93 PITARU, S. et al Partial regeneration of periodontal tissues using collagen barriers. Initial observations in the canine. J Periodontol, v.59, n.6, p.380-6, June 1988. 
94 PITARU, S. et al. Heparan sulfate and fibronectin improve the capacity of collagen barriers to prevent apical migration of the junctional epithelium. J Periodontol, v.62, n.10, p.598-601, Oct. 1991.

PONTORIERO, R.; LINDHE, J. Guided tissue regeneration in the treatment of degree II furcations in maxillary molars. J Clin Periodontol, v.22, n.10, p.756-63, Oct. 1995.

PONTORIERO, R.; LINDHE, J. Guided tissue regeneration in the treatment of degree III furcations in maxillary molars. J Clin Periodontol, v.22, n.10, p.801-2, Oct. 1995.

POSTLETHWAITE, A.E.; SEYER. J.M.; KANG, A.H. Chemotactic attraction of human fibroblasts to type I, II, and III collagens and collagen-derived peptides. Proc Natl Acad Sci U S A, v.75, n.2, p.871-5, Fev. 1978 apud WANG, H-L.; CAROLL, W.J. Guided bone regeneration using bone grafts and collagen membranes. Quintessence Int, v.32, n.7, p.504-15, 2001.

98 RAMFJORD, S.P. et al. Results following three modalities of periodontal therapy. J Periodontol, v. 46, n.9, p.522-6, Set. 1975.

RIPAMONTI, U.; REDDI, A.H. Periodontal regeneration: potential role of bone morphogenetic proteins. J Periodontal Res, v.29, n.4, p.225-35, July 1994.

100 SABLEMAN, E. Biology, Biotechnology and Biocompatibility of collagen. Biocompatibilty of tissue analog, Boca Raton, FL: CRC Press,: 27. 1985 apud WANG, H-L.; CAROLL, W.J. Guided bone regeneration using bone grafts and collagen membranes. Quintessence Int, v.32, n.7, p.50415, 2001.

101 SACCONI, A.L. Não erre mais. São Paulo: Companhia Editora nacional, 1977.

102 SALONEN, J.I., PERSSON, G.R. Migration of epithelial cells on materials used in guided tissue regeneration. J Periodontal Res, v.25, n.4, p.21521, July. 1990.

103 SANCHEZ, M.P.R.; CESTARI, T.M.; TAGA, E.M.; TAGA, R. Avaliação microscópica em ratos (Wistar albinus) de implantes de matriz de osso bovino liofilizado "Biograft" + proteína morfogenética + membrana reabsorvível de osso bovino liofilizado "Dentolflex". BCI - Revista Brasileira de Cirurgia e Implantrodontia, v.7, n.27, p.30-9, Jul./Ago./Set., 2000. 
104 SANDBERG, E.; DAHLIN, C.; LINDE, A. Bone regeneration by the osteopromotion technique using bioabsorbable membranes: an experimental study in rats. J Oral Maxillofac Surg, v.51, n.10, p.110614, Oct. 1993.

105 SANZ, M.; GIOVANNOLI, J.L. Focus on furcation defects: guided tissue regeneration. Periodontol 2000, v.22, p.169-89, Feb. 2000.

106 SCHENK, R.K. Bone regeneration:biologic basis in: BUSER, D., DAHLIN, C., SCHENK, R.K. Guided bone regeneration in implant dentistry. 1 ed., Quintessence books, 1994.

107 SCHENK, R.K. et al. Healing pattern of bone regeneration in membraneprotected defects: a histologic study in the canine mandible. Int J Oral Maxillofac Implants, v.9, n.1, p.13-29, Jan./Feb. 1994.

108 SCHLEGEL, A.K. et al. Preclinical and clinical studies of a collagen membrane (Bio-Gide). Biomaterials, v.18, n.7, p.535, Apr. 1997 apud WANG, H-L.; CAROLL, W.J. Guided bone regeneration using bone grafts and collagen membranes. Quintessence Int, v.32, n.7, p.504-15, 2001.

109 SCHLIEPHAKE, $\mathrm{H}$. et al. Use of a mineralized collagen membrane to enhance repair of calvarial defects in rats. Clin Oral Implants Res, v.15, n.1, p.112-8, Feb. 2004.

110 SCHMITZ, J.P.; HOLLINGER, J.O. The critical size defect as an experimental model for craniomandibulofacial nonunions. Clin Orthop, v. 205, p.299-308, Apr. 1986.

111 SCHMITZ, J.P. et al. Characterization of rat calvarial nonunion defects. Acta Anat. (Basel) v. 138, n. 3, p. 185-92, 1990.

112 SCOTT, T.A. et al. Comparison of bioabsorbable laminar bone membrane and non-resorbable ePTFE membrane in mandibular furcations. J Periodontol, v.68, n.7, p.679-86, July. 1997.

113 SEIBERT, J.; NYMAN, S. Localized ridge augmentation in dogs: a pilot study using membranes and hydroxyapatite. J Periodontol v.61, n.3, p.157-65, Mar. 1990.

114 SEVOR, J.J., MEFFERT, R.M., CASSINGHAM, R.J. Regeneration of dehisced alveolar bone adjacent to endosseous dental implants utilizing a resorbable collagen membrane: clinical and histologic results. Int J Periodontics Restorative Dent v.13, n.1, p. 71-83, 1993.

115 SILVERSTEIN, L.H.; KRAFT, J.D.; WAND R. Bone regeneration and tissue acceptance of human fascia lata grafts adjacent to dental implants: a preliminary case report. J Oral Implantol, v.18, n.4, p. 394-8, 1992. 
116 SIMION, M. et al. A comparative study of the effectiveness of e-PTFE membranes with and without early exposure during the healing period. Int J Periodontics Restorative Dent, v.14, n.2, p.166-80, Apr. 1994.

117 SOO, C.; RAHBAR, G.; MOY, R.L. The immunogenicity of bovine collagen implants. J Dermatol Surg Oncol, v.19, n.5, p.431-4, May 1993 apud WANG, H-L.; CAROLL, W.J. Guided bone regeneration using bone grafts and collagen membranes. Quintessence Int, v.32, n.7, p.50415, 2001.

118 STAL, S. et al. Compartmentalized bone regeneration of cranial defects with biodegradable barriers: an animal model. J Craniofac Surg, v.12, n.1, p.41-7, Jan. 2001.

119 TAGA, R.; HASSUNUMA, C.Y.; CESTARI, T.M.; FERREIRA, P.M. Destino de membrana de cortical óssea bovina colocada em posição subperióstica na calvária de cobaia. Ver Brasil Implant, v.3, n.6, p. 24-9, nov./dez., 1997.

120 TAGA, R.; CESTARI, T.M.; TAGA, E.M.; ASSIS, G.F.; MARINE, M.G. Avaliação histológica, radiográfica e morfométrica da reparação de defieto ósseo perene em crânio de cobaia tratado com mistura de Osseobond e Biohapatita e membrana absorvível de cortical óssea bovina. JBE- Jornal Brasileiro de Endo/Perio, v.1, n.1, p.78-87, 2000.

121 TANNER, M.G.; SOLT, C.W.; VUDDHAKANOK, S. An evaluation of new attachment formation using a microfibrillar collagen barrier. J Periodontol, v. 59, n.8, p.524-30, Aug. 1988.

122 TEN CATE, A.R. Repair and regeneration of dental tissue. In Oral histology. Development ,structure and function. 4. ed. St. Louis, Mosby, 1994. p. 456-68.

123 TIMPL, R. Antibodies to collagens and procollagens. Methods Enzymol, v.82, n.Pt A, p.472-98, 1982 apud WANG, H-L.; CAROLL, W.J. Guided bone regeneration using bone grafts and collagen membranes. Quintessence Int, v.32, n.7, p.504-15, 2001.

124 TINTI, C.; VINCENZI, G.; COCCHETTO, R. Guided tissue regeneration in mucogingival surgery. J Periodontol, v. 64, n. 11 Suppl, p.1184-91, Nov. 1993 .

125 UNSAL, B.et al. An investigation of resorption and tissue reaction after subcutaneous implantation of collagen based membrane materials in rats. J Marmara Univ Dent Fac, v.2, n.4, p.609-15, Sept. 1997. 
126 WANG, C.L. et al. Collagen-induced platelet aggregation and release. II Critical size and structural requirements of collagen. Biochim Biophys Acta, v.544, n.3, p.568-77, Dec. 1978 apud WANG, H-L.; CAROLL, W.J. Guided bone regeneration using bone grafts and collagen membranes. Quintessence Int, v.32, n.7, p.504-15, 2001.

127 WANG, H.L.; MACNEIL, R.L. Guided tissue regeneration. Absorbable barriers. Dent Clin North Am, v.42, n.3, p.505-22, July. 1998.

128 WANG, H-L.; CAROLL, W.J. Guided bone regeneration using bone grafts and collagen membranes. Quintessence Int, v.32, n.7, p.504-15, 2001.

129 WEBER, T. et al. Transmission of Creutzfeldt - Jakob disease by handling of dura mater. Lancet, v.341, n.8837, p.123-4, 1993.

130 WIKESJÖ, U.M.E.; NILVÉUS, R.E.; SELVIG, K.A. Significance of early healing on periodontal repair: a review. J Periodontol, v.63, n.3, p.15865, Mar. 1992.

131 WILDERMAN, M.N. et al. Histogenesis of repair following osseous surgery. J Periodontol, v. 41, n.10, p.551-65, Oct. 1970.

132 YAFFE, A.; EHRLICH, J.; SHOSHAN, S. Restoration of periodontal attachment employing enriched collagen solution in the dog. $\mathbf{J}$ Periodontol, v.55, p.623-8, 1984 apud WANG, H-L.; CAROLL, W.J. Guided bone regeneration using bone grafts and collagen membranes. Quintessence Int, v.32, n.7, p.504-15, 2001.

133 YAMAOKA, S.P. et al. Clinical evaluation of demineralizedunicortical-illium-strips for guided tissue regeneration. J. Periodontol, v.67, n.8, p.803-15, Aug. 1996.

134 YUKNA, R.A. Clinical human comparison of expanded polytetrafluorethylene barrier membrane and freeze-dried dura mater allografts for guided tissue regeneration of lost periodontal support. I. Mandibular molar class II furcations. J Periodontol, v.63, p.431-42, 1992.

135 ZAHEDI, S. et al. Evaluation of a diphenylphosphorylazide-crosslinked collagen membrane for guided bone regeneration in mandibular defects in rats. J Periodontol, v.69, n.11, p.1238-46, Nov. 1998.

136 ZITZMANN, N.U., NAEF, R., SCHARER, P. Resorbable versus nonresorbable membranes in combination with Bio-Oss for guided bone regeneration. Int J Oral Maxillofac Implants, v.12, n.6, p844-52, Nov./Dec. 1997. Erratum in: Int J Oral Maxillofac Implants, v. 13, n.4, p.576, July/Aug.. 1998. 
137 ZITZMANN, N.U.; SCHARER, P.; MARINELLO, C.P. Long-term results of implants treated with guided bone regeneration: a 5-year prospective study. Int J Oral Maxillofac Implants, v.16, n.3, p. 355-66, May/June 2001. 
Abstract 


\section{ABSTRACT}

Collagen materials has been extensively used in medicine and dentistry due to its biologic and physical properties. The aim of this work was to evaluate histologically and morphometrically the repair of critical size bone defects promoted by double demineralized bovine cortical laminar bone sheets (Gen-derm, 250-300 m of thickness). A bone defect of $10 \mathrm{~mm}$ diameter was produced the calvarium of 40 guinea pigs. In 20 animals the inner aperture of the defect was protected by laminar bone sheet above the duramater and after fulfilled with blood clot, the outer aperture was covered with a second bone sheet. A shank of inactive demineralized allogenic bone (3 mm diameter) was used as space maintainer. The defect of the control group was fulfilled with blood clot and a central space maintainer. The skulls were collected 1,3, 6 and 9 months after surgeries. Morphometrically and histologically the experimental group showed substantial increase in the bone growth starting at the border of the defects. At 1 and 3 months woven bone occupied 31,7\% and 59,9\% (versus $21,3 \%$ and $38,6 \%$ of the control), respectively, of the defect area. In two cases at 6 and at 9 months occurred the total fulfillment of defect with lamellar bone. In these two last periods the new bone occupied in mean $81,9 \%$ and $96,2 \%$ of the defects respectively, while the control group the mean area was 55,4\% and 45,4\%, respectively. The multiple linear regression with Bonferroni`s correction applied on the data of the radiographic morphometry showed a significant statistical diference between the groups at the time of 6 and 9 months. The results obtained here indicated 
that the use of double demineralized bovine cortical laminae bone sheets and a space maintainer promoted a good repair of critical size calvarium defects. 